\title{
Analytical and Computational Methods for the Assessment of Biological Molecules and their Binding Interactions: Case Studies in DNA Aptamer-Target Binding and P450-P450 Dimerization
}

Katherine M. Hickey

Follow this and additional works at: https://researchrepository.wvu.edu/etd

\section{Recommended Citation}

Hickey, Katherine M., "Analytical and Computational Methods for the Assessment of Biological Molecules and their Binding Interactions: Case Studies in DNA Aptamer-Target Binding and P450-P450 Dimerization" (2015). Graduate Theses, Dissertations, and Problem Reports. 5797.

https://researchrepository.wvu.edu/etd/5797

This Dissertation is protected by copyright and/or related rights. It has been brought to you by the The Research Repository @ WVU with permission from the rights-holder(s). You are free to use this Dissertation in any way that is permitted by the copyright and related rights legislation that applies to your use. For other uses you must obtain permission from the rights-holder(s) directly, unless additional rights are indicated by a Creative Commons license in the record and/ or on the work itself. This Dissertation has been accepted for inclusion in WVU Graduate Theses, Dissertations, and Problem Reports collection by an authorized administrator of The Research Repository @ WVU.

For more information, please contact researchrepository@mail.wvu.edu. 


\title{
ECONOMIC ACTIVITY AND THE ASSOCIATION OF SPENDING RATE AND SPENDING RATE VOLATILITY ON BORROWING COST
}

\author{
Anna W. Hickey \\ Dissertation submitted \\ to the College of Business and Economics \\ at West Virginia University
}

in partial fulfillment of the requirements for the degree of

Doctor of Philosophy in

Business Administration

Concentration in Accounting

Jack W. Dorminey, Ph.D., Chair

Barbara Apostolou, Ph.D.

Nicholas G. Apostolou, D.B.A.

Eric Olson, Ph.D.

Department of Accounting

Morgantown, West Virginia

2017

Key words: municipal bond market, information content, spending rate, borrowing cost, financial crisis

Copyright (C) 2017 Anna Hickey 


\title{
ABSTRACT \\ ECONOMIC ACTIVITY AND THE ASSOCIATION OF SPENDING RATE AND SPENDING RATE VOLATILITY ON BORROWING COST
}

\begin{abstract}
Anna W. Hickey
Achieving minimum borrowing cost for municipal bonds is an ongoing concern. Apostolou, Apostolou, and Dorminey (2014) demonstrated that a fund accounting measure, spending rate magnitude (i.e., the absolute value of general fund revenues minus general fund expenditures) proxied for management's ability to balance revenues and expenditures. Their findings indicated that achieving balance at spending rate equilibrium (i.e., where general fund revenues equal general fund expenditures) was associated with minimum borrowing cost, and that the magnitude of departure from spending rate equilibrium was associated with higher borrowing cost. Little is known regarding the information content of spending rate in the years during and after the financial crisis that started in 2007. Given the crash of the housing bubble and severe reductions to property tax revenues, municipalities experienced a prolonged recovery that was characterized by a change to borrowing patterns and deficit spending. In this study, I extended from Apostolou et al. (2014) and examined whether the information content of spending rate was conditional to levels of economic activity. I accomplished this by using state leading indexes compiled by the Federal Reserve Bank to proxy for local economic activity. Based on a sample of 1,970 general obligations bonds that were issued by U. S. counties between 1995 through 2014, I tested three conditional hypotheses for significant interaction between economic activity and spending rate magnitude. Results indicated that the association between spending rate magnitude and borrowing cost was positively moderated by economic activity. Positive moderation was also significant for spending rate surpluses (i.e., where general fund revenues exceed general fund expenditures). These results suggest that departures from spending rate equilibrium are more severely assessed on borrowing cost when economic activity is positive, and less severely assessed on borrowing cost when economic activity is negative. Overall, my findings provide preliminary evidence that managerial competence over the balance of revenues and expenditures is evaluated more severely when economic conditions are good not when they are bad.
\end{abstract}




\section{DEDICATION}

To my husband Tom, for his unconditional support during my studies. 


\section{ACKNOWLEDGEMENTS}

I extend my deepest appreciation to my committee chair, Professor Jack Dorminey. His generosity and willingness to work with me throughout this $\mathrm{PhD}$ journey has been instrumental to my success at WVU. I am eternally grateful for his patience, guidance, and mentorship.

I also extend a special thanks to Professor Barbara Apostolou. Through her mentorship, I've gained an appreciation for the hard work that goes into writing a research paper. I am also extremely grateful to my other committee members, Professor Nicholas Apostolou and Professor Eric Olson, for their support and expertise throughout this dissertation process.

I thank my mom, Rosa, who taught me the value of academic achievement. I also thank my dearest friends, Camilla and Grace, for their constant encouragement.

Lastly, I thank my former and current colleagues at the U. S. Coast Guard Academy, who believed me worthy of pursuing a PhD for the future education of our cadets. 


\title{
ECONOMIC ACTIVITY AND THE ASSOCIATION OF SPENDING RATE AND SPENDING RATE VOLATILITY ON BORROWING COST
}

\author{
TABLE OF CONTENTS
}

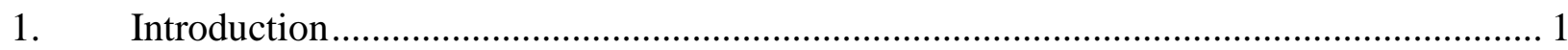

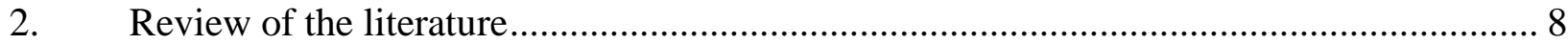

2.1. Information content of earnings in the corporate bond market.......................................... 8

2.2. Information content of spending rate (SR) in the municipal bond market ....................... 14

2.3. Information content of historic volatility in earnings and spending rate (SR) ................. 21

2.4. The financial crisis of 2007 and the impacts on the municipal bond market ................... 25

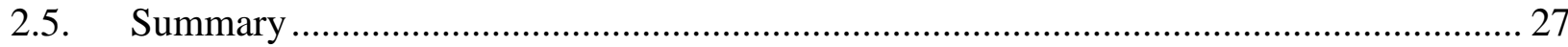

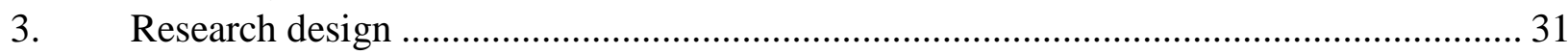

3.1. Hypothesis development ............................................................................................... 31

3.1.1. The moderating effect of economic activity on SR and TIC ........................................... 31

3.1.2. The moderating effect of economic activity on SR volatility and TIC............................. 33

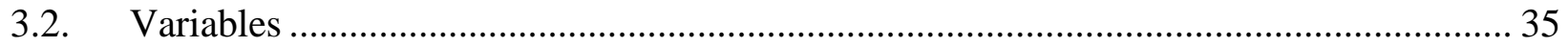

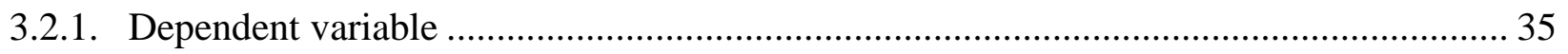

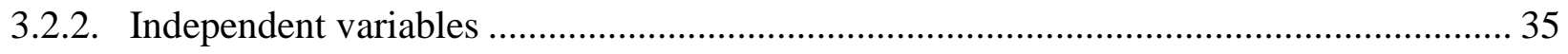

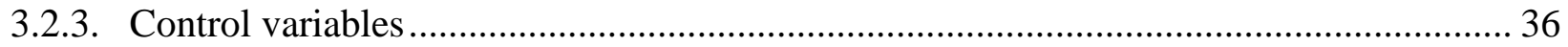

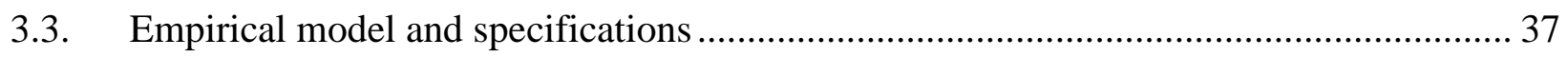

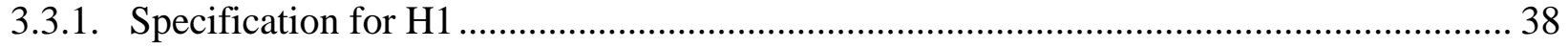

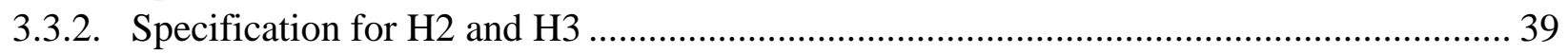

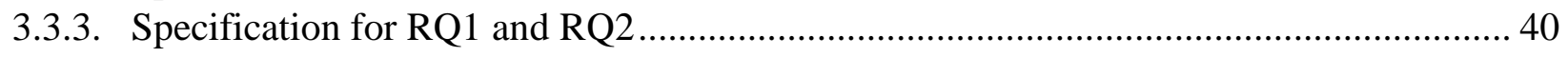

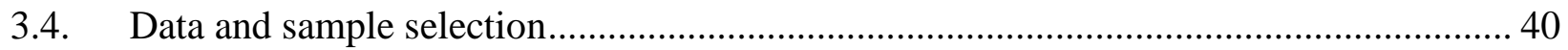

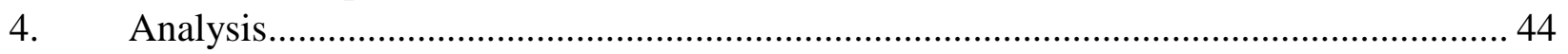

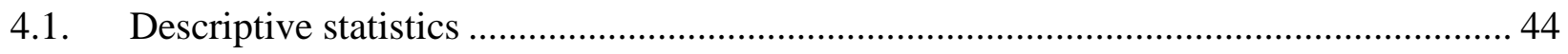

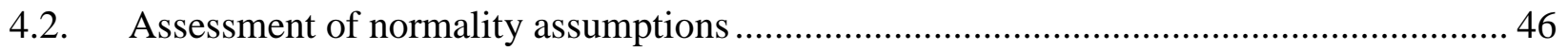

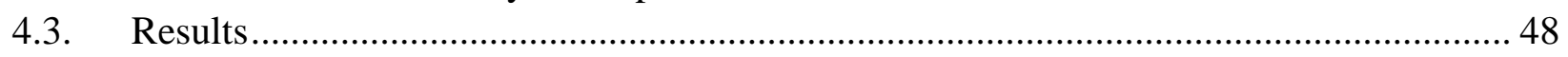

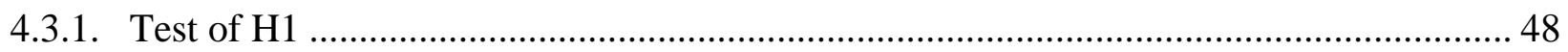

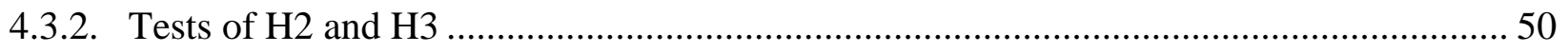

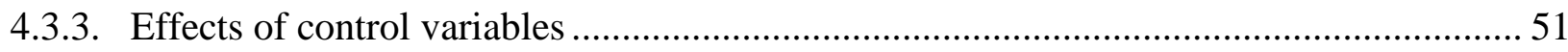

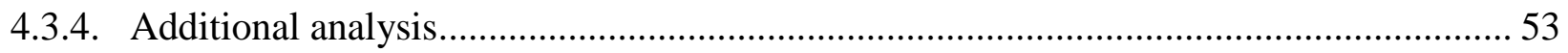

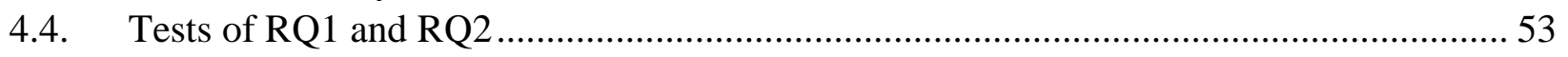

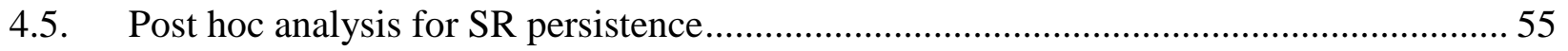

4.5.1. Theory and model specification for SR persistence ……................................................. 55

4.5.2. Subsample selection................................................................................................... 56

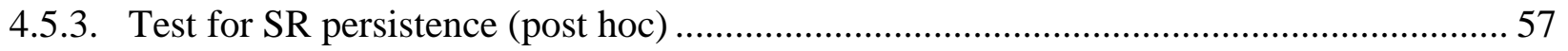

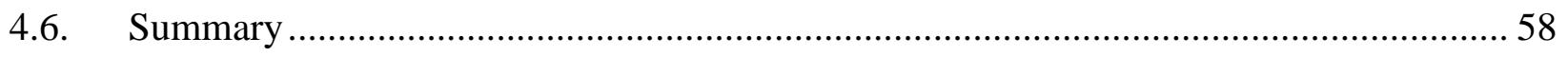

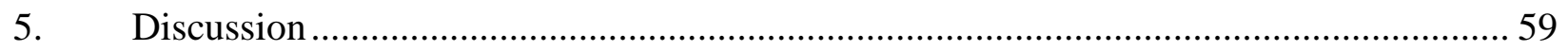

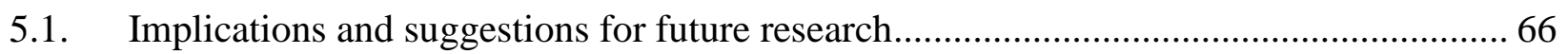

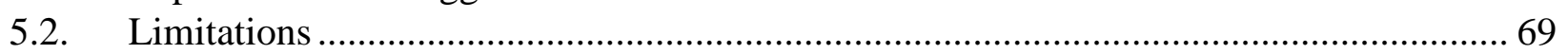

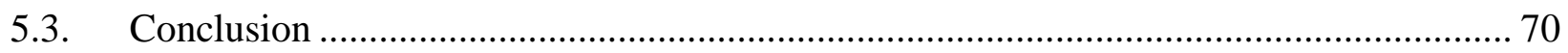

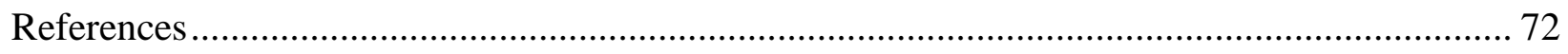




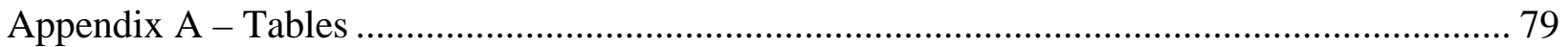

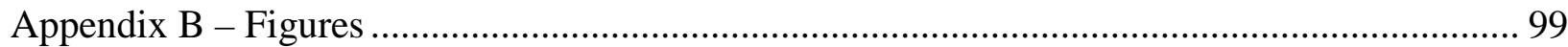

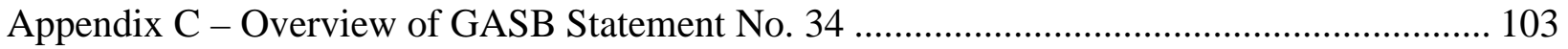




\section{ECONOMIC ACTIVITY AND THE ASSOCIATION OF SPENDING RATE AND SPENDING RATE VOLATILITY ON BORROWING COST}

\section{Introduction}

In a public statement on the state of the U. S. municipal bond market, SEC Commissioner Luis Aguilar stated, “There is perhaps no other market that so profoundly influences the quality of our daily lives” (2015). The municipal bond market has served as a critical source of financing for local governments to build and to maintain infrastructure. Since the 1980s, the municipal bond market has experienced significant growth from an estimated \$361 billion in outstanding debt to \$3.7 trillion by 2012 (Securities Exchange Commission, 2012). As of late 2016, the Federal Reserve reported the total debt outstanding among state and local governments to be approximately $\$ 3.1$ trillion. $^{1}$

Relative to the size of the U. S. bond market (\$39.0 trillion) and the U. S. stock market (\$26.3 trillion), the size of the municipal bond market might appear small (Barr, 2015).

However, when compared to the level of federal investment on infrastructure, the importance of the municipal bond market is essential to maintaining and improving the quality of life for U. S. citizens (Istrate, 2013). Between 2003 and 2012, investment on infrastructure by states and local governments with borrowings from the municipal bond market was 2.5 times greater than federal investment (Istrate, 2013). ${ }^{2}$ Furthermore, the low default and tax-exempt benefits of the municipal market have made it an attractive and relatively secure option for long-term investors. As of 2013, approximately 75 percent of municipal bond holders consisted of American

\footnotetext{
${ }^{1}$ Found in Table D.3. of the Federal Reserve Statistical Release for the third quarter, Financial Accounts of the United States, dated 08 December 2016.

${ }^{2}$ Compiled under the National Association of Counties (NACO). NACO combined statistics from Thomson Reuters, the U. S. Office of Management and Budget (OMB), and the U. S. Congressional Research Service (CRS).
} 
households that were investing in their local communities while diversifying retirement portfolios (Istrate, 2013). Thus, the viability of the municipal bond market has had important implications for household investors.

The viability of the municipal bond market also depends on the cost of borrowing. For municipalities, keeping borrowing cost at a minimum is important, as current year resources expended for interest payments could otherwise be used for other priorities. On average, municipalities issue approximately $\$ 0.5$ trillion annually in new bond issuances, incurring significant borrowing cost in the process (Ang \& Green, 2011). Although borrowing cost is to be expected, there remains concern among the SEC that municipalities pay too much due to inefficiencies in the market (Ang \& Green, 2011; Aguilar, 2015). One source of inefficiency is in the issuance process itself. Municipal issuers have relied on myriad networks of underwriters and financial intermediaries just to access and/or to sell in the primary market (Istrate, 2013; Liu, 2015). On average, municipalities incur approximately eighty-nine basis points in direct underwriter fees and another twenty-eight basis points when underwriters resell bonds to investors in the secondary market (Ang \& Green, 2011). Taken together, municipalities have participated in a market that bears extranneous borrowing cost. Thus, keeping borrowing cost at a minimum is one way to maintain its viability as a critical source of financing for municipalities.

The financial crisis that began in late 2007 and the subsequent Great Recession of 2008 changed the landscape of the municipal bond market. ${ }^{3}$ One major change was greater regulatory oversight from the Dodd-Frank Act of 2010, which carried several new requirements. For

\footnotetext{
${ }^{3}$ The Great Recession of 2008 partially overlapped with the financial crisis and recovery periods. Hereafter, for the sake of consistency, I refer to just the financial crisis and recovery periods throughout the paper.
} 
example, municipal bond financial advisors are now required to register with the Municipal Securities Rulemaking Board (MSRB) (Liu, 2015). Borrowing patterns among municipalities also changed. As of 2014, new bond issuances in this market hit their lowest since 1991 (Pew Charitable Trusts, 2016b). This dramatic change in borrowing patterns was unlike that of other economic downturns. Furthermore, despite the Federal Reserve Board's maintenance of low interest rates from 2010 to 2014, the volume of new bond issuances continued to decline (Pew Charitable Trusts, 2016b). This is not to say, however, that municipalities were not borrowing. Pew Charitable Trusts (2016b) reported consistent and high refinancing of municipal bonds during the recovery period. Furthermore, the SEC was concerned about a growing trend in municipal borrowing via direct loans instead of via new bond issuances (Aguilar, 2015).

The financial crisis also increased the risk associated with the municipal bond market, (PwC, 2014). Greater risk was largely driven by the reduction in tax-based revenues, which are essential to the municipality's ability to pay its obligations (PwC, 2014). Reduction in key revenues was largely attributed to declines in property values and property tax revenue, and state aid to local governments (Gross, Huh, Sylvester, \& Zahradnik, 2012). Combined, these revenue sources accounted for more than half of the revenue among local governments (Gross et al., 2012; Atwell, Fehr, Huh, \& Russell, 2013). Furthermore, these effects were prolonged into the recovery period for municipalities due to the lag in property value assessments and tax collections. Pew Charitable Trusts (2016a) reported wide variation in financial recovery after the financial crisis among 30 of the largest metropolitan cities. As of fiscal year 2013, 16 major cities still experienced record declines in property tax revenues and 21 experienced further declines in state and federal aid (Pew Charitable Trusts, 2016a). 
Given the presence of greater risk from the financial crisis and the unstable and slower recovery, stakeholders in the bond markets may have relied more on accounting information to make decisions. Givoly, Hayn, and Katz (2017) provided evidence that the information content of earnings in the corporate bond market has greater relevance during times of economic downturn. Their finding suggested that economic activity, as proxied by the U. S. gross domestic product (GDP), is significant to the information content of corporate earnings and its association to various measures that are priced by the market (e.g., borrowing cost, bond returns, and yield spreads).

In the municipal setting, spending rate (SR) is a measure of short-term financial performance of a municipality's chief operating fund, called the "general fund" (Reck \& Wilson, 2014). ${ }^{4}$ Plummer, Hutchinson, and Patton (2007) defined SR as a "modified-accrual earnings measure...that resembles changes to working capital accruals.” At fiscal-year end, SR indicates whether the governmental reporting entity is in a current-year surplus (revenues > expenditures), a current-year deficit (revenues $<$ expenditures), or a balanced condition (revenues $=$ expenditures) (e.g., Apostolou, Giroux, \& Welker, 1985; Plummer et al., 2007). Importantly, extant literature has identified SR as a signal to the market regarding the quality of fiscal management over revenues and expenditures in the current year, relative to an adopted budget (e.g., Apostolou, 1982; Pridgen \& Wilder, 2013; Apostolou, Apostolou, \& Dorminey, 2014).

True interest cost (TIC) is the preferred measure of borrowing cost arising from the issuance of municipal debt (Simonsen \& Robbins, 2002). TIC captures the time value of money and is dynamic to changes in the interest rates in the market (Simonsen \& Robbins, 2002;

\footnotetext{
${ }^{4}$ Statement No. 34 of the Governmental Accounting Standards Board (GASB) outlines the financial reporting model for state and local governments. The general fund is considered a major fund and is common to all municipalities that report per GASB Statement No. 34. An overview of the governmental financial reporting model and additional information on SR is provided in Appendix C.
} 
Plummer et al., 2007; Reck \& Wilson, 2014). Governmental accounting studies that have examined the association between SR and borrowing cost in the 1980 to 1990 timeframe primarily used net interest cost (NIC). While other alternative measures have been explored, TIC is currently the most appropriate, timely, and comprehensive measure of borrowing cost. In practice, the Government Finance Officers Association (GFOA) recommends TIC as a "best practice” measure of borrowing cost (1994).

In a recent study by Apostolou et al. (2014), the authors reconciled mixed results from previous governmental accounting studies on the association between SR and borrowing cost (TIC). Apostolou et al. (2014) found a positive association between borrowing cost (TIC) and the absolute value of SR (i.e., SR magnitude). Their study was based on a sample of newly issued general obligation bonds over a thirteen-year period, from 1995 to 2007. The authors described a positive association between SR magnitude and TIC as being nonlinear, nonmonotonic, and asymmetric around the SR equilibrium point (i.e., SR $=0$, where general fund revenues equal general fund expenditures). In other words, incremental deviations in either direction of SR equilibrium are assimilated by the market and priced as higher borrowing cost.

The purpose of this study was to examine whether economic activity had differential effects on SR and its association to borrowing cost, as measured by TIC. Givoly et al. (2017) identified economic activity as a key variable to the information content of earnings information in the corporate bond market. I extended on this finding in the municipal setting. If the information content of SR in the municipal bond market is assessed similarly to that of earnings in the corporate bond market, then TIC should be priced differently given different levels of economic activity. While the extant literature has established an association between SR and 
TIC, the extant literature does not directly address the potential for a dependency in the association of SR and TIC on economic activity.

To address this research gap, I used a modified extension of Apostolou et al.’s (2014) empirical models to examine the association between SR magnitude and TIC, conditioned on different levels of economic activity. The sample consisted of 1,970 newly issued general obligation bonds issued by U.S. counties across a twenty-year period, from 1995 through 2014. To proxy for variations in economic activity, I used the state leading indexes reported by the Federal Reserve Bank of Philadelphia. The state leading indexes provide a composite measure of local economic inputs (Puenpatom \& Stark, 2016). A series of OLS regressions were employed to test three hypotheses. For the first hypothesis, I tested whether the SR-TIC association was moderated by economic activity. Evidence from the corporate bond literature suggested that earnings information is more relevant during economic downturns. Accordingly, I expected a significant interaction between SR magnitude and the state leading index, given that nearly half of the observations in the sample were from periods of extreme economic instability.

Apostolou et al. (2014) found asymmetry in the associations between TIC and the magnitudes of SR surpluses and SR deficits, respectively. Accordingly, for the second and third hypotheses, I separately tested the SR-TIC association for both deficits and surpluses, conditioned on levels of economy activity. Lastly, I posed two research questions to explore whether the SR-TIC association was significant when SR was transformed to its second moment as a near-term, historic volatility measure. Dichev and Tang (2008) explained that earnings volatility captures economic shocks, but that earnings volatility also provides greater information content to predict future earnings. The information content of SR volatility has not been explored in the governmental accounting context. From a research standpoint, studying a 
characteristic of SR, within the context of the financial crisis, may provide incremental knowledge on the pricing of TIC in the municipal bond market during periods of economic turmoil.

I make two contributions in this study. First, I provide an expanded examination of SR and its association to TIC across twenty years (1995-2014). This period included the years leading up to the financial crisis that started in 2007, and the subsequent years following this event. Arnold (2009) provided a self-critique of accounting research surrounding the financial crisis of 2007. She offered that the body of accounting knowledge failed to anticipate the financial crisis and encouraged research that addresses theoretical links between the macroeconomic environment and micro-accounting. Given the changing landscape of the municipal bond market after the financial crisis, this study answers the call by examining the relative importance of governmental accounting information in pricing new municipal bond issuances across alternative economic environments. Second, I ascertain whether Apostolou et al.'s (2014) findings hold during periods of extreme financial turbulance. The authors developed empirical models that well-proxied for the prevailing interest environment using yield curve attributes. Thus, testing their models with observations from the financial crisis and recovery years provides additional validation on the extendibility of their findings.

This remainder of this study is organized as follows. Chapter 2 covers the relevant literature. Chapter 3 covers the sample, hypothesis development, variable definitions, and model specifications. Chapter 4 summarizes the results. Chapter 5 discusses the findings, limitations, and conclusions of the study. 


\section{Review of the literature}

This literature review consists of four sections. The first section consists of select literature that provided evidence of market efficiency in the corporate bond market via earnings information. Six studies were selected; four studies highlighted the conditions in which earnings information is associated to bond investor reactions and two studies provided evidence that earnings is a key variable in lowering a firm's cost of debt. While cost of debt broadly refers to the rate that a firm pays for all its borrowings, I only focused on the cost of debt related to corporate bonds.

In the second section, I drew a parallel between corporate earnings and SR, based on Plummer et al.’s (2007) description of SR as a measure of modified-accruals earnings. In doing so, I focused on a narrow stream of governmental accounting literature that began with Wallace (1981). The governmental accounting literature provides consistent evidence that SR has information content and is associated to the borrowing cost of municipal bonds.

To lay the groundwork for studying SR volatility, the third section features a combination of public finance and corporate literature that illustrate greater explanatory power in earnings volatility and a general motivation among managers to maintain smoothness in both earnings and SR. Importantly, the fourth section contextualizes the recent financial crisis and the after-effects. Within this section, the role of accounting information surrounding the financial crisis and the economic consequences faced by municipalities are provided as foundational background for my study.

\subsection{Information content of earnings in the corporate bond market}

Extant literature provided evidence that bondholders and shareholders both seek accounting information regarding firm performance. But the informational needs between 
bondholders and shareholders differ fundamentally. With respect to earnings information, the bondholders are more concerned in the firm's income-generating ability to make promised principal and interest payments (Kothari, Ramanna, \& Skinner, 2010). Considering this, bondholders are inclined to place greater relevance on the downside risk from negative earnings (i.e., losses), which may signal the possibility of weak future cash flows (Plummer \& Tse, 1999; Givoly et al., 2017). Conversely, equity holders are more inclined to view the same earnings information with consideration of potential growth opportunities and the ability of earnings to convey future profitability (Givoly et al., 2017).

Another fundamental difference between bondholders and shareholders is inherent to the nonlinear payoff structure of bonds. In general, the bondholder's interest payments and payoff is fixed (Easton, Monahan, \& Vasvari, 2009). As such, the relevance of positive or negative earnings information diminishes beyond a certain level for bond holders (Easton et al., 2009; Givoly et al., 2017). Several studies in the corporate finance and accounting literature provided evidence that earnings are relevant to reactions in the U. S. corporate debt market. The literature captured the relevance of earnings information in two ways: (1) the association between earnings information to bond investor reactions, as quantified by bond returns, bond trading activity, and/or bond-price changes, and (2) the association between earnings and a firm's cost of debt.

Plummer and Tse (1999) tested for differences in the association between earnings changes versus bond returns and stock returns, respectively, while controlling for the financial strength of the firm. Financial strength was proxied by the firm's bond rating and a reported loss or profit in earnings. Importantly, the authors found that the financial strength of the firm was an important variable, particularly when earnings information conveyed bad news (i.e., a loss). Based on the liquidation option hypothesis, the authors predicted that as bond ratings decreased 
(i.e., greater presence of default risk), the relationship between stock-returns and earnings would decrease, while the relationship between bond-returns and earnings would increase. The authors used a sample of corporate bond observations $(n=4,983)$ from 1986 through 1993. The sample was partitioned by reported losses and gains, and by bond rating levels. Within each subsample, the authors estimated cumulative abnormal returns (CAR) and cumulative bond returns (CBR) as a function of changes to earnings per share (EPS). The model for CBR also controlled for macroeconomic movements with the inclusion of the U. S. Treasury bond index. Results were consistent with the liquidation option hypothesis; specifically, the bond returns-earnings relationship was stronger than the stock returns-earnings relationship, for the firms in poor financial condition (i.e., losses and low bond ratings). This finding highlighted the importance of downside risk in earnings and the importance of controlling for the firm's financial condition. Additionally, the authors also found that investment-grade bonds were highly correlated with economic trends, as proxied by the U. S. Treasury bond index, but that below-investment grade bonds were not significantly correlated.

In a related study, Easton et al. (2009) found that the association between unexpected earnings and bond trading activity was stronger when earnings conveyed bad news. Easton et al. (2009) used the nonlinear payoff structure of bonds to make two hypotheses regarding the role of earnings in the corporate debt market: (1) that the relevance of earnings information would depend on whether earnings conveys good news or bad news, and (2) that given the bondholder's diminishing sensitivity to the level of earnings losses or gains, the relevance of earnings information would further depend on the level of default risk. Based on a sample of corporate bond issues from 1994 through 2006 ( $n=10,237)$, the authors examined bond trading prices within a 61-day event window of bond earnings announcements. Consistent with Plummer and 
Tse (1999), two major findings surfaced from their analysis. First, the association of bond investor reaction to earnings information was greatest when earnings conveyed bad news; this is evidenced through increased bond trading activity and bond-price reactions within the event window. Second, the relevance of earnings information was strongest amongst the higher-risk bonds in the sample, suggesting that the relevance of earnings information was associated not only with whether earnings conveys good news or bad news, but also with the risk of default. Importantly, Easton et al.’s (2009) findings implied that managers may have a disincentive to report bad news to the market before seeking capital from the corporate bond market.

Defond and Zhang (2014) found that earnings information is also relevant to the timeliness of reactions in the corporate debt market. The authors analyzed whether bond market reaction, quantified by cumulative abnormal bond returns, adjusted to quarterly earnings releases during three event windows: pre-announcement period $(-20,-1)$, announcement period $(-1,+1)$, and post-announcement period $(+2,+20)$. Parallel comparisons to stock market reactions were also conducted via cumulative abnormal stock returns. The analysis of timeliness in bond versus stock reactions was conducted by partitioning the sample $(n=11,641$ quarterly earnings announcements and 47,522 bond-year observations from 1996 through 2006) by good versus bad news, for each of the three event windows. Main results indicated that bond reactions were significant and symmetric (between good and bad news) within the earnings announcement window $(-1,+1)$. However, within the other event windows, the relation between bond returns and earnings became asymmetric, whereby there was greater significance associated with bad news. This asymmetry was most pronounced in the pre-announcement period. In other words, the "...majority of bond reaction to bad news occurs before the earnings announcement date" (Defond and Zhang, 2014, 924). Furthermore, when compared to stock market reactions, the 
authors found opposite and asymmetric associations. Specifically, stock market reactions became stronger in their association with good news in the pre-announcement and announcement periods. Unlike bond reactions, most of the stock market reactions occurred within the 3-day announcement period $(-1,+1)$. Supplementary analysis also revealed that these findings were most pronounced among the speculative-grade bonds in the sample. In sum, the evidence was consistent with prior literature that suggested earnings losses were more relevant to bondholders. Moreover, DeFond and Zhang (2014) extended the literature with evidence that suggested an overreaction by bondholders in anticipation of bad news.

Givoly et al. (2017) studied whether the information content of accounting numbers in the corporate bond market versus the equity market changed over a 39-year period, from 1975 through 2013. The authors predicted that accounting information should have increased in its relevance over time in the corporate bond market, due to a greater focus on balance sheet effects (i.e., fair-value accounting) and a growing trend towards accounting conservatism. Both factors positively contributed to a greater reliance on financial statements for creditors. To test their prediction, Givoly et al. (2017) used a large sample of corporate bonds ( $n=13,910$ bond series issued by 2,754 firms) to assess the association between various accounting numbers and bond (equity) returns and bond (equity) valuations, respectively. The authors found strong evidence that the information content of accounting numbers, as measured by adjusted R-squared values, increased over time in the corporate bond market. In comparison, the association between equity returns and valuations declined over the sample period. The authors also regressed information content on various economic and reporting factors. Results revealed that information content was significantly and negatively associated to the state of the economy (i.e. GDP), suggesting 
that accounting numbers have greater information content for corporate bondholders during periods of financial distress.

Corporate literature also demonstrated that earnings information is associated to the firm's cost of debt. Jiang (2008) tested whether beating earnings benchmarks was related to reductions in the cost of debt. Assuming stakeholders applied benchmarks as heuristics for evaluating firm performance, Jiang (2008) hypothesized that beating these benchmarks should lessen the information-processing costs for stakeholders and thus, lower the firm's cost of debt. Based on prospect theory, Jiang (2008) predicted that people would be more sensitive to potential losses than gains, relative to a point of reference. Accordingly, Jiang rationalized that managers have an incentive to beat earnings benchmarks in order to avoid negative opinions among external stakeholders. Two samples were used that proxied for cost of debt (the credit ratings for $n=8,878$ for firms from 1985-2002, and the initial yield spread for $n=1,798$ newlyissued corporate, nonconvertible, fixed-rate bonds from 1983-2002). Three benchmarks were established based on earnings per share (EPS): beating zero earnings, beating last year’s earnings, and beating the most recent analyst's forecasted earnings. Three hypotheses were tested. Results for H1 indicated that beating any of the benchmarks was associated with a higher probability of a credit ratings upgrade and smaller yield spreads. This suggested lower cost of debt for firms. Results for H2 showed that high-default-risk firms benefitted more in reducing the cost of debt when beating the zero-earnings and previous year's earnings benchmarks.

Results for H3 showed that beating the zero-earnings benchmark had a greater impact on the cost of debt, as compared to the other benchmarks.

Bharath, Sunder, and Sunder (2008) viewed borrowing cost (i.e., cost of debt) as a function of the information risk associated with the quality of accounting information and its 
ability to estimate future cash flows. Specifically, Bharath et al. (2008) compared the quality of accounting information associated with corporate bonds (public debt) and bank loans (private debt). The authors also studied the impact of accounting-information quality on the borrower's choice in pursuing public versus private debt. Using principal components analysis, a composite measure of accounting quality was developed from three different estimations of abnormal accruals. ${ }^{5}$ These estimations collectively proxied for the mismatch between earnings and operating cash flows and the influence of discretionary accounting choices (Bharath et al., 2008, 2). Based on a sample of firms that had both corporate bond and bank loans ( $n=3,681$ bonds and $n=12,676$ loans from 1988 through 2003), Bharath et al. (2008) found that higher accounting quality was associated with lower cost of debt, as measured by smaller interest rate spreads. Furthermore, the authors found that the probability of pursuing corporate bonds increased as accounting quality increased, and that bank loans had significantly higher interest costs than corporate bonds. The authors also found that firms in higher risk of default obtained more bank loans than corporate bonds (significant at the 0.010 level). Taken together, these findings suggest that the quality of earnings and cash flow information is associated with both the cost of debt, and a firm's propensity to pursue private or public debt.

\subsection{Information content of spending rate (SR) in the municipal bond market}

The corporate bond literature provided ample and supporting evidence of market responses to earnings information (e.g., bond returns, trading activity, levels of default risk, changes in timing, and cost of debt). Analogous to corporate earnings, the revenue and expenditure accounting information represented by SR provides a measure of financial operating performance for a municipality. A narrow stream of governmental accounting literature provides

\footnotetext{
${ }^{5}$ Abnormal accruals were estimated using variations of the modified-Jones model.
} 
evidence that SR has information content to responses in the municipal bond market. The governmental accounting literature has focused largely on market responses related to default risk and/or the cost of debt that the issuer incurred (i.e., the borrowing cost of municipal bonds). Measures commonly used to capture market responses have been net interest cost, variations of yield spreads, bond ratings, and true interest cost. Seven studies were selected and are discussed, starting with Wallace (1981). Wallace's (1981) investigation on the information content of municipal accounting numbers was a catalyst for much of the literature presented in this section.

Wallace (1981) studied whether variations in bond ratings and borrowing cost (net interest cost, or NIC) were associated with accounting and auditing variables that were perceived important by municipal market participants. The sample consisted of general obligation (GO) bonds and revenue utility bond issues from the State of Florida for years 1974 to 1976 . Wallace conducted OLS and probit regressions on the full sample ( $n=106$ issues) and on a subsample ( $n$ $=73$ city issues). OLS regression for the full sample yielded no significance in auditing and accounting variables until Wallace removed bond ratings from the regression, which yielded a significant association between NIC and accounting variables. OLS regression for the subsample resulted in significance for both auditing and accounting variables. Importantly, SR was found to be positively associated with NIC, which implied that a deficit in the general fund could be positively associated with lower borrowing cost. Wallace rationalized that the modified accrual basis for fund accounting warranted earlier recognition of expenditures and thus, an SR deficit could be perceived as a positive signal to the market that municipal managers did not distort the accounting information (p. 510).

Ingram and Copeland (1982) studied non-callable GO bonds $(n=122)$ that were sold in the secondary market in 1977. The authors hypothesized that municipalities under more rigorous 
reporting requirements would exhibit lower systematic risk, smaller yield premiums, and smaller changes in yield premium. The authors conducted a series of stepwise regressions with three different dependent variables: yield premium, change in yield premium, and the systematic risk of each municipality. ${ }^{6}$ Independent variables consisted of 28 accounting financial ratios, bond ratings, economic measures, and quality measures for audit, accounting, and financial management reporting practices required by the state. SR for this study was measured as a change in SR across two periods. The quality of reporting practices was captured with ordinal measures to proxy for the degree of relative strength of each state requirement. Results showed that the presence of accounting regulations by the state was significant to reducing systematic risk.

Wilson and Howard (1984) replicated and extended on Wallace's work with a larger sample $(n=230)$ and methodological improvements. Their sample consisted of only GO bond issues in the primary market from municipalities across the U.S. from 1978 through 1981. Like Wallace (1981), Wilson and Howard used the same dependent variables of bond ratings and NIC. Primary independent variables were selected based on a combination of quality accounting and auditing measures from governmental accounting literature and reported accounting practices. Probit analysis was used to estimate bond ratings and OLS regression was used to estimate NIC. Overall, the authors found greater association of accounting and auditing information with NIC and bond ratings. As it related to SR, Wilson and Howard found that

\footnotetext{
${ }^{6}$ To determine systematic risk, the authors estimated $\beta$ (beta). The model specification resembles the capital asset pricing model, in which the pricing of an asset is a function of a risk-free rate and the expected market return, and the coefficient for the expected market return is beta. In this case, Ingram and Copeland (1982) estimated the average change in yield premium for each municipality, as a function of a risk-free rate and the monthly bond market portfolio; the coefficient for the monthly market portfolio is the systematic risk or beta that was used as a dependent variable.
} 
higher SR balances (both surplus and deficit) were negatively associated to NIC. Like Wallace (1981), this latter finding seemed counterintuitive for a deficit balance.

Apostolou et al. (1985) reconciled prior mixed results in a study of GO serial bonds ( $n=$ 478) that were issued by Minnesota municipalities in 1977 through 1980. For this study, a single dependent variable (NIC) was tested in three OLS regressions: a reduced base model, a linear SR model, a nonlinear SR model. Primary independent variables consisted of SR, information from a regional market index, and the average maturity of a serial bond. The authors employed a nonlinear regression model that used a binary variable to isolate the difference between a negative SR slope and a positive SR slope. The results provided initial evidence that the rate of surplus and deficit spending is positively associated to NIC. Accordingly, Apostolou et al. (1985) were the first authors to suggest a relation between SR and NIC as nonmonotonic around a balanced-budget point. In sum, given a government's goal to maintain a balanced budget, a divergence from a balanced condition signals suboptimal oversight of the adopted budget and thus, net interest cost (NIC) increases with any departure from a balance in revenues and expenditures.

Apostolou et al. (2014) addressed mixed findings from previous studies and revised an $a$ priori expectation of a linear relationship between spending rate and borrowing cost. The authors applied several methodological improvements on a sample of GO bonds $(n=3,285)$, issued by 314 counties among 36 states. The sample period for their study spanned thirteen years, from 1995 to 2007. The authors defined SR equilibrium as the point where SR equals zero, which proxied for managerial competence. ${ }^{7}$ Any deviations from SR equilibrium, in either a surplus or

\footnotetext{
${ }^{7}$ For this study, Apostolou et al. (2014) transform SR from a ratio of revenues over expenditures (where revenues/expenditures $=$, $>$ or $<1$ ), to the magnitude of the difference between revenues minus expenditures (where revenues - expenditures $=0,+$ or - ). Thus, SR magnitude equal to zero has the same
} 
deficit direction, were represented by SR magnitude (the absolute value of general fund revenues minus general fund expenditures). Larger SR magnitudes implied a lesser ability by management to maintain a balance between actual revenues and expenditures. The authors hypothesized a positive association between SR magnitude and TIC.

Foundational to their investigation were empirical models that estimated TIC as a function of SR magnitude with control variables that proxied for the yield curve. Yield curve attributes were captured by three measures: the average maturity of the bond issue in years, the natural log of the same, and the federal funds rate. The federal funds rate is the interest rate established among lending institutions that maintain deposits at Federal Reserve banks. ${ }^{8}$ In lieu of the conventional Bond Buyer Index, Apostolou et al. $(2014,15)$ use the federal funds rate as a "direct observation of... underlying rates from which bonds are actually priced." In doing so, the authors introduced a proxy for the prevailing interest rate, based on a monetary policy. Results indicated that the federal funds rate was statistically significant and positively associated with TIC. The authors concluded that the association between SR magnitude and TIC is positively associated and follows a non-monotonic, nonlinear, and asymmetric profile:

(1) The non-monotonic aspect of the model occurred at the equilibrium point ( $\mathrm{SR}=0$ ), where the sign of the slope of the association changed. As SR magnitude increased, in either direction of a surplus or deficit, the slope of the association between spending rate and borrowing cost was positive (i.e., higher TIC).

meaning as SR equal to 1 for a balanced condition, as previously defined by Apostolou, Giroux, and Welker (1985).

${ }^{8}$ A lower federal funds rate would indicate expansionary monetary policy and lower interest rates. A higher federal funds rate would translate to higher interest levels and in this context, higher borrowing cost for municipalities. 
(2) The nonlinear aspect of the model explained that the increase in borrowing cost was not uniform as the departure from SR equilibrium increased. Instead, a nonlinear function that resembled a total utility curve captured the diminishing marginal effects of interest rate properties in a yield curve under a normal economy. In sum, as SR magnitude increased in either the surplus or deficit directions, the nonlinearity of SR indicated that its positive association with TIC marginally diminished.

(3) Depending on whether there is an SR surplus or deficit, the association between SR and TIC was found to be asymmetric. The authors conjectured that a negative departure from equilibrium (i.e. a deficit) was conveyed to the market more quickly and induced a higher borrowing cost than a positive departure (i.e., a surplus).

(4) One control variable, unassigned fund balance scaled by county population, indicated a statistically significant and negative relationship with TIC.

Two recent studies, Plummer et al. (2007) and Reck and Wilson (2014), addressed whether accrual-based accounting information provided incremental information over modifiedaccrual accounting information, per the GASB Statement No. 34 financial reporting model. Importantly, both studies found significance of SR in assessing default risk.

Plummer et al. (2007) focused on three measures (net assets, revenues minus expenditures, and current liabilities) from both levels of the governmental financial reporting model (i.e., accruals measures were from government-wide financial statements and modifiedaccruals measures were from governmental funds statements). The authors studied a sample of Texas school districts $(n=530)$ for fiscal year 2002 and estimated default risk as a function of the financial statement variables from both levels of financial reporting. Default risk was 
captured by transforming each school district's underlying bond rating to a rank from 1 to $14 .^{9}$

As it pertained to revenues minus expenditures for the general fund, Plummer et al. (2007) found that the accruals earnings measure was not superior to the modified accrual earnings measure (i.e. SR is superior) when assessing default risk. Furthermore, the authors found that credit ratings were less favorable for both deficits and surpluses; this finding is consistent with Apostolou et al. (1985) and Apostolou et al. (2014), who found that the municipal bond market assimilated greater risk for deviations in either direction of SR equilibrium. Plummer et al. (2007) concluded that the best combination of measures for assessing default risk was with SR and the accruals measure for total net assets.

Similarly, Reck and Wilson (2014) tested for the incremental informativeness of government-wide accounting information that is reported per GASB Statement No. 34. The authors used a combination of NIC and TIC observations as their dependent variable. Their sample consisted of GO bonds $(n=185)$ issued by municipalities in the 2002 through 2006 . The main empirical model estimated borrowing cost as a function of bond issue attributes, market factors, fiscal and socioeconomic factors. Consistent with Plummer et al. (2007), the authors showed that SR and unassigned fund balance (both modified-accruals based) and long-term government-wide measures (accruals-based) were incrementally informative to explaining borrowing cost. Specifically, the results suggest that the municipal bond market relies primarily on SR and the general fund's fund balance to assess borrowing cost (p. 54). However, unlike Plummer et al. (2007) the authors found a negative relationship between SR surpluses and borrowing cost.

\footnotetext{
${ }^{9}$ Plummer et al. (2007) acknowledged that the ideal measure of default risk was with a continuous variable (e.g., bond yields). However, data constraints warranted the use of bond ratings instead.
} 


\subsection{Information content of historic volatility in earnings and spending rate (SR)}

One time-series property of earnings is its volatility. In general, volatility is a measure of variability over time (Taylor, 2005). Volatility can be interpreted and measured in different ways (e.g., historic volatility, implied volatility, stochastic volatility) (Taylor, 2005). Of interest in this study is the historical volatility of SR, which is broadly described as the historical standard deviation of previously reported earnings (Taylor, 2005). ${ }^{10}$

In this section, earnings volatility is defined from the perspective of Dichev and Tang (2008 \& 2009). As a part of this discussion, I briefly revisited Givoly et al. (2017) to highlight the relevance of earnings volatility in the corporate bond market. Next, I examined whether earnings volatilty matters to market participants with respect to managing risk. If risk levels change in the presence of volatility information, then it's possible that there is incremental information content in earnings volatility, relative to the level-measure of earnings. Two studies, Graham et al. (2005) and Erickson et al. (2016), were selected from the corporate literature to provide evidence that volatility matters to market participants. Combined, these studies provided evidence that earnings volatility is significant to explaining variations in perceived risk among managers and investors. Transitioning to the municipal setting, Felix (2015) provided evidence that municipal managers, like corporate managers, have motivation to maintain smoothness in earnings (i.e., to keep SR near zero for the general fund). Lastly, Gore (2009) provided evidence that revenue volatility, a major component of SR, may potentially have adverse implications in the municipal setting.

Dichev and Tang $(2009,161)$ explained that earnings volatility can be attributed to two factors: (1) volatility from economic shocks and (2) volatility from difficulties at the firm level in

\footnotetext{
${ }^{10}$ This historical characteristic of earnings is consistent with the definition in the recent accounting literature (e.g., Dichev \& Tang, 2008 and 2009; Givoly et al., 2017; Erickson et al., 2017).
} 
determining income. Using accounting information from U. S. firms over 40 years $(n=1,000$ firms from 1967 through 2003), Dichev and Tang (2008) presented a theory that mathematically relates the two previous factors to reported earnings. Essentially, when there is perfect matching between revenues and expenditures (i.e., all the costs of the firm's operations are perfectly matched to its associated revenues), then earnings volatility is entirely driven by economic factors related to the firm's business environment (Dichev \& Tang, 2008, 1428). Further, Dichev and Tang $(2008,1428)$ showed that “...the volatility of earnings is increasing in the volatility of economic shocks and in the persistence of these shocks over time”.

Consequently, any mismatching between revenues and expenditures will increase the volatility of earnings (i.e., introduce "noise" to the economic representation of earnings). Results also revealed that the trend of mismatch in revenues and expenditures over time has increased over the 40-year period and has led to greater volatility in earnings (Dichev \& Tang, 2008). ${ }^{11}$ Consistent with Dichev and Tang (2008), Givoly et al. (2017) also found that earnings volatility was significantly and positively associated to their proxy for information content. Givoly et al.'s (2017) results further indicated that the information content of earnings volatility steadily increased in its association to bond returns and valuations across the 39-year period.

Erickson, Hewitt, and Maines (2017) found differential reactions between smooth versus volatile earnings among investors. In an experiment, the authors tested for variations in investors' risk judgements when evaluating earnings volatility, relative to the volatility of cash flows. Based on attribution theory, the authors predicted investors would attribute opportunistic reporting to environmental factors first, rather than blame managers for possible malintent. Using a 2 x 2 between-subjects design, the authors manipulated earnings (volatile vs. smooth)

\footnotetext{
${ }^{11}$ Dichev and Tang (2008) also explained that poor matching will decrease the persistence of earnings and bring about more negative autocorrelation in earnings changes (p. 1456).
} 
and operating cash flow (volatile vs. smooth). The sample of participants consisted of businessschool alumni from a large university ( $n=121$ alumni, 6.7\% response rate). Participants were given four years of financial data and asked to provide investment risk judgments based on a 13point scale. The findings revealed that investors perceived a higher level of risk when both earnings and operating cash flow were volatile. ${ }^{12}$

Graham, Harvey, and Rajgopal (2005) surveyed CFOs among public and private companies ( $n=401$ in the year 2003,10.4\% response rate) on reporting decisions related to earnings. Across most of the sample, the authors found that CFOs placed tremendous weight on earnings information (relative to cash flows). Moreover, most of the CFOs (78\%) preferred to avoid reporting volatile earnings because they believed that volatile earnings were riskier for investors and stakeholders (p. 5, 66). In one-on-one interviews among a subsample of CFOs ( $n$ $=20$ ), the authors asked clarifying questions and found additional supporting evidence that meeting or exceeding earnings benchmarks could reduce the cost of debt for bond covenants. The authors found that this concern was most pronounced among CFOs from private firms and highly-leveraged and unprofitable public firms (p. 28-29).

There is limited evidence that municipal managers, like corporate managers, also avoid volatility in earnings. In the municipal setting, the optimal "earnings" benchmark is at SR equilibrium, or when revenues equal expenditures in the general fund (Apostolou et al., 1985; Apostolou et al., 2014). Municipal managers have an incentive to maintain SR at or near zero, despite a prior surplus or deficit (Felix, 2015). Large surpluses (SR>0) can signal excessive

\footnotetext{
12 Erickson et al. (2017) also conducted a second experiment that tested whether investors would give managers the "benefit of the doubt" when earnings are smooth versus volatile. The authors found support that investors also had different perceptions of risk when managers were afforded different levels of reporting discretion (high versus low) and incentive (high versus low) when determining the accruals for each period. Results show that investors' risks heighten when they have additional information (incremental to earnings and cash flow volatility) to support earnings management.
} 
collection of tax revenue or insufficient spending of expenditures for public services (Felix, 2015). On the other hand, large deficits $(S R<0)$ might signal poor management of public resources and/or an inability to adhere to balanced budget rules (Felix, 2015; Costello et al., 2017). Based on a hand-collected sample of municipalities $(n=103)$ from 2001 through 2003, Felix (2015) found that municipal managers used inter-fund transfers to maintain SR near zero across the sample period. Furthermore, this practice was most pronounced when municipal managers were subject to greater oversight and credit monitoring.

There is scant literature related to the information content of SR volatility in the municipal bond market. However, Gore (2009) provided initial evidence that the revenue component of SR can carry adverse implications if there is extreme revenue volatility. Gore (2009) found that revenue volatility was positively correlated with the presence of state level revenue (i.e., intergovernmental funds) ${ }^{13}$, growth, changes in total taxes, and administrative spending. Similar to estimations of historical earnings, Gore estimated revenue volatility using a coefficient of variation, defined as the ratio of the standard deviation of revenue to the mean revenue over the sample period across four years. Using a sample of U. S. municipalities ( $n=$ 9,413 from 1997 through 2002), Gore (2009) found that revenue volatility was positively and significantly associated with high levels of cash and that these higher cash levels were significantly associated with agency problems. Gore proxied for agency problems by testing the association between excess cash levels and increases to city manager salaries, bonuses, and administrative spending. Whether volatility in revenues manifested into SR volatility is

\footnotetext{
${ }^{13}$ As an aside, Trussel and Patrick (2013) found that the most important predictor of impending fiscal distress in municipalities, as measured by a reduction in public services, is a high level of dependence on intergovernmental revenues, relative to total revenues.
} 
unknown. However, her study provided preliminary evidence that revenue volatility, in the extreme, was not consistent with signs of good fiscal stewardship among municipal managers.

\subsection{The financial crisis of 2007 and the impacts on the municipal bond market}

The shift in accounting standards to fair value practices was a major contributing factor to the U. S. financial crisis that started in late 2007 (Kothari \& Lester, 2012). Under a prosperous economy that began in 2001, the shift to fair value accounting practices permitted the recognition of inflated gains on securitized assets among lending institutions. In turn, these gains were repackaged and sold as new loans. Concurrently, the prevalence of poor lending practices, particularly by lenders in the sub-prime mortgage market, facilitated higher-risk home purchases (Kothari \& Lester, 2012, 347). Many of the mortgages were debt contracts that were constructed with adjustable interest rates. When the Federal Reserve Board started to raise interest rates in 2005, the default on mortgages drastically increased as homeowners struggled to support higher mortgage payments (Kothari \& Lester, 2012, 347). The widespread defaults in the sub-prime mortgage market eventually led to the failure and/or collapse of large lending institutions (e.g., Bear Stearns, Merrill Lynch, and Lehman Brothers). The relatively fast decline in the U. S. financial sector also resulted in massive unemployment across the country as companies initiated large-scale employee layoffs (Kothari \& Lester, 2012, 347).

Municipalities were also severely affected by the financial crisis. Numerous defaults on mortgages and the decline in real estate prices left local governments with a "one-two punch,” as property tax revenues and state aid declined (Gross et al., 2012). Combined, these two revenue sources accounted for more than half of local revenues (Gross et al., 2012). On the expenditures side, municipal managers were simultaneously faced with greater demands for public services stemming from the lagged effects of population growth during periods of economic prosperity, 
prior to the financial crisis (Atwell et al., 2013; McDonald III, 2015). Unlike the private sector, the recovery period following the crisis was particularly difficult for local governments. Gross et al. (2012) reported that in past recessions, property taxes, on average, remained steady given that real estate prices were not drastically affected. The recent financial crisis, however, uniquely affected the housing market on a large scale, which significantly reduced property tax revenues. ${ }^{14}$ Coupled with the fact that property tax reassessments have a lagged effect on the collection of tax revenues, the effects of the financial crisis extended further into the recovery period for municipalities (Gross et al., 2012; Atwell et al., 2013).

Most municipalities addressed impending fiscal distress through a combination of raising taxes, cutting spending, dipping into fund balance reserves to close out year-end deficits, and short-term borrowing via short-term municipal bonds (Gross et al., 2012; Atwell et al., 2013). A significant motivator for states to intervene over municipal finances was the potential for a downgrade to credit ratings at the state level due to the possibility of "contagion" effect, whereby credit downgrades across multiple municipalities could also damage the state's credit ratings (Atwell et al., 2013, 15).

Literature on the impact of the financial crisis on the municipal bond market is sparse. Park, Matkin, and Marlowe (2017) studied the association between internal control deficiencies and municipal bond borrowing cost. The authors used TIC as their dependent variable and estimated TIC as a function of internal control deficiencies, market conditions, and issue characteristics. Results showed that higher borrowing cost for municipal bonds was associated with the most severe internal control deficiencies (i.e., material weaknesses). Their study was based on a sample of newly issued municipal bond issues $(n=3,633)$, for the period 2005

\footnotetext{
${ }^{14}$ As an example, Gross et al. (2012) reported that home prices in Arizona fell nearly 50 percent from 2007 to 2011.
} 
through 2012, for California, Texas, and Washington. The authors made an additional prediction that the internal control-TIC association would be more salient during the financial crisis and the subsequent period of recovery. The authors used binary variables to code the years of the financial crisis (2008 for financial crisis; 2009-2010 for recovery) and then tested for significance in the interaction terms between each economic period and material weakness indicators. The interaction terms were not statistically significant for bonds issued in the financial crisis period.

\subsection{Summary}

The corporate literature provided evidence that earnings has information content that is associated with various market responses (e.g., bond returns, trading activity). Common among the corporate literature was the sensitivity of bondholders to downside risk in earnings. In a recent study, Givoly et al. (2017) found that the information content of earnings in the corporate bond market has steadily increased in its relevance and that this upward trend can be largely attributed to the shift to fair value accounting practices and accounting conservatism; both of which contribute to a greater reliance by creditors to accounting information. Importantly, Givoly et al. (2017) also found significance that both economic (e.g., GDP) and reporting factors were significant to information content of earnings in the corporate bond market. Most relevant to this study was the negative relationship of GDP to information content, suggesting that the information content of accounting information is more relevant during economic downturns.

A modified-accruals measure of "earnings" in the municipal setting is the SR reported on general fund performance. Analogous to the literature that supports the importance of earnings information to the corporate bond market, a narrow stream of governmental accounting literature supports the importance of SR to the municipal bond market. Starting with Wallace (1981), 
these governmental accounting studies consistently provided evidence that SR has information content to responses in the municipal bond market.

The assessment of both earnings and/or SR information involved a benchmark. Jiang (2008) demonstrated that the zero-earnings benchmark is the most salient benchmark and that beating this benchmark (i.e., reporting a profit) is significantly associated with lower cost of debt among firms participating in the corporate bond market. In the governmental accounting literature, three studies (Apostolou et al., 1985; Plummer et al., 2007; Apostolou et al., 2014) suggested that "beating the benchmark" in the municipal setting was in maintaining the zero benchmark at SR equilibrium, where revenues equal expenditures.

Among some of the governmental studies, measurement of SR varied given the inclusion of different deflators. For example, Apostolou et al. (1985) used revenues divided by expenditures (i.e., revenues/expenditures). Apostolou et al. (2014) used revenues less expenditures scaled by population (i.e., (revenues-expenditures)/population). Plummer et al. (2007) and Reck and Wilson (2014) used revenues less expenditures scaled by revenues (i.e., (revenues-expenditures)/revenues). Despite the differences in deflators, they all represented measures of general fund performance. Importantly, the government accounting literature is consistent with the notion that better general fund performance is associated with lower relative risk, which is associated with lower borrowing cost.

Dichev and Tang (2008) demonstrated that earnings volatility varied with the volatility of economic shocks. Graham et al. (2005) and Felix (2015) showed that CFOs and municipal managers preferred smoothness in earnings and SR, respectively. Erickson et al. (2016) provided evidence of differential risk levels in the presence of both earnings and cash flow volatility. Gore (2009) provided related evidence that revenue volatility, in the extreme, may be 
associated with agency problems in the municipal setting. Givoly et al. (2017) also showed that the volatility of core net income is positive and significant to information content in the corporate bond market. If SR is assessed by the municipal bond market as earnings is in the corporate bond market, then evaluating its volatility may also provide greater insight on its information content, particularly given the economic shock from the financial crisis that started in 2007.

An overall assumption among all the studies is that the accounting information is based on GAAP financial statements. Bharath et al. (2008) provided evidence that the quality of accounting information matters and that firms with lower accounting quality tended to seek financing from banks instead of through corporate bonds. In the municipal setting, Park et al. (2017) also showed that accounting quality matters. Specifically, material weaknesses in GAAP reporting were associated with higher municipal borrowing cost. Interestingly, Park et al. (2017) found no significant difference in borrowing cost in the financial crisis and early recovery periods.

Clear evidence exists that municipalities were adversely affected by the financial crisis and that these effects extended well into the recovery period (Gross et al., 2012; Atwell et al., 2013). Specifically, Atwell et al. (2013) reported higher incidences of credit downgrades, reduced levels of revenues, and higher incidences of municipal distress and financial crisis. How these circumstances manifested to changes in relative risk assessments in the municipal bond market is yet to be fully understood, as only two studies (Givoly et al., 2017 and Park et al., 2017) included samples that extended into the financial crisis and post-financial-crisis periods. Although Park et al. (2017) studied the municipal bond market, their study focused on only three U. S. states and their model did not include SR as a variable to estimate borrowing cost. Givoly 
et al.’s (2017) study provided foundational information on the importance of economic activity on information content in earnings; but their study was solely focused on the corporate bond market. This leaves an obvious research gap for further inquiry into the information content of SR and the municipal bond market. Table 1 in Appendix A provides a summary of the literature. 


\section{Research design}

This chapter presents the sample, hypotheses, variables, and empirical models for this study. Development of three hypotheses and two research questions were based on a combination of corporate and governmental accounting literature. Sample selection involved the use of four data sources to study a sample of GO bonds issued by U. S. counties. Model specifications to estimate TIC were based on OLS models defined by Apostolou et al. (2014). Consistent with Apostolou et al. (2014), statistical analyses incorporated the employment of a series of OLS regressions and the application of fixed effects for panel data.

\subsection{Hypothesis development}

\subsubsection{The moderating effect of economic activity on SR and TIC}

Givoly et al. (2017) found that the information content of accounting numbers were negatively associated with economic factors, as proxied by GDP. This finding suggested that accounting information was more relevant to bondholders as economic activity declined. The governmental accounting literature provided evidence that the municipal bond market also evaluated accounting information and that SR was a key variable. The financial crisis and recovery have changed the risks associated with municipal bonds, as evidenced through credit downgrades and more incidences of fiscal distress (Atwell et al., 2013; PwC, 2014). These additional risks should be assimilated on TIC. I extend from the findings of Givoly et al. (2017) and predict that in the municipal bond market, SR is more relevant to the pricing of TIC as economic activity declines. This suggests that economic activity has a moderating effect on the SR-TIC relationship. H1 is stated as follows:

H1: The association between spending rate magnitude and borrowing cost is moderated by economic activity. 
Apostolou et al. (2014) provided strong evidence that the association between SR and TIC was asymmetric for surpluses and deficits. In the corporate literature, DeFond and Zhang (2014) also found asymmetry in earnings losses and profits in the pre- and post- announcement periods. Thus, to test potential asymmetries in SR deficits and SR surpluses, two additional hypotheses are established.

Corporate literature consistently supported the sensitivity of market reactions to earnings losses in the bond market, largely due to the potential risk of default (Plummer \& Tse, 1999; Jiang, 2008; Easton et al., 2009; Givoly et al., 2017). A major consequence of the financial crisis was a decline in key revenue sources among municipalities, which resulted in greater deficit spending (Atwell et al., 2013). If the municipal bond market assesses SR deficits similarly to earnings losses in the corporate debt market, then municipalities with SR deficits should be assessed as being in higher risk of default, which should further be associated with higher borrowing cost (i.e., TIC) in a poor economy. Thus, I offer that the association between SR deficits and TIC should be more salient when economic activity is low. H2 is stated as follows:

H2: Negative departures from SR equilibrium (SR deficits) are assessed more severely on TIC as economic activity declines.

SR surpluses represent deviations from SR equilibrium in the positive direction. SR surpluses were found to be positively associated with TIC (Apostolou et al., 1985; Plummer et al., 2007; Apostolou et al., 2014). The corporate literature also suggested that given the nonlinear payoff function of bonds, the sensitivity of bondholders to greater levels of positive earnings (or surpluses) diminishes beyond a certain point. However, results from Reck and Wilson (2014) showed that SR was negatively related to borrowing cost, suggesting that surpluses were associated with lower borrowing cost. In short, the results were mixed as it pertained to SR surpluses and its association to borrowing cost for municipal bonds. 
In periods with low economic activity (i.e., poor condition), I posit that SR surpluses are viewed more favorably than in periods with high economic activity. Two reasons support this assertion. The first reason is based on the idea of unexpected earnings. Per the corporate literature, unexpected positive earnings were associated with lower cost of debt (Jiang, 2008; Bharath, 2008). During the financial crisis, the general expectation among municipalities, given drastic reductions in key revenue sources and growing public expenditures was deficit spending during the fiscal year (Gross et al., 2012). Consequently, municipalities had to use reserves to maintain SR equilibrium. Atwell et al. (2013) discussed that during the financial crisis, municipalities dipped into their fund balance reserves more frequently to cover year-end deficits and that a declining fund balance was a warning signal of impending financial distress and/or crisis. Thus, a municipality that could achieve SR surplus at fiscal year-end sent an unexpected and positive signal to the market during periods of poor economic condition.

A second reason is inherent to the recalibration of municipal bond ratings that began in early 2010. Moody's new rating methodology quantitatively rewards SR surpluses with higher credit ratings (Praagh \& Dorer, 2010). Moody's uses an SR equal to 1 (revenues/expenditures) to indicate balanced budget operations. An SR equal to 1 is rated "A" while an SR greater than 1 (i.e. a surplus) receives an "A" or above. Likewise, an SR less than 1 (deficit) receives a rating below “A.” Taken together, I posit that during economic downturns, SR surpluses reduce the relative risk assessed by municipal market participants. H3 is stated:

H3: Positive departures from SR equilibrium (SR surpluses) are assessed less severely on TIC as economic activity declines.

\subsubsection{The moderating effect of economic activity on SR volatility and TIC}

Corporate studies supported the notion that managers and investors avoid volatility in earnings because greater volatility is associated with greater risk (Graham et al., 2005; Erickson 
et al., 2017). Similar to the corporate sector's preference for smoothness in earnings, I offer that municipal managers and investors in the municipal bond market also prefer smoothness in SR. This is also supported by Felix (2015), who provided evidence that municipal managers were motivated to maintain stability of SR at or near zero with interfund transfers. If the municipal bond market perceives SR volatility as a signal of uncertainty in future cash flows, then they should perceive greater risk in SR and this risk should be assimilated on TIC.

Dichev and Tang (2009, 161) explained that earnings volatility among firms can be attributed to large shocks in the economy. The financial crisis created a shock to economic activity that adversely affected municipalities (Gross et al., 2012; Atwell et al., 2013). If SR volatility, like earnings volatility, captures shocks in economic activity, then there should be greater SR volatility during the financial crisis and recovery periods. Greater SR volatility should be associated with greater relative risk. Thus, during these economic periods, accounting information on SR volatility should also have greater relevance to the municipal bond market. This suggests that the association between SR volatility and TIC is stronger during economic downturns. In sum, SR volatility, like corporate earnings, may provide information content to the municipal bond market. If so, then the information content of SR should also be moderated by economic activity. Thus, I explore the information content of SR volatility by addressing two research questions:

RQ1: Is TIC associated with SR volatility?

RQ2: Is the association between TIC and SR volatility moderated by economic activity? 


\subsection{Variables}

\subsubsection{Dependent variable}

The dependent variable is TIC. TIC includes several underlying costs related to bond issuance (e.g., finance charges, discount points, possible late fees, prepaid interest, and the time value of money) (Simonsen \& Robbins, 2002). TIC is also a continuous variable that better captures the effects of accounting information on borrowing cost (Plummer et al., 2007; Reck and Wilson, 2014). Reck and Wilson (2014) noted that TIC is superior to bond ratings, since bond ratings are adjusted at longer intervals. In contrast, TIC captures the default risk in the market at the time of issuance. The GFOA also identifies TIC as a "best practice" measure of borrowing cost (GFOA; Simonsen \& Robbins, 2002).

\subsubsection{Independent variables}

Two independent variables are studied. The first independent variable is spending rate magnitude (SR). Consistent with Apostolou et al. (2014), the magnitude of SR will be used for hypothesis testing (to be discussed later in section 3.3). For RQ1, I adopt the approach used by Gore (2009) for revenue volatility to calculate SR volatility. Specifically, SR volatility is calculated as the coefficient of variation, which is the standard deviation of SR, scaled by the mean of SR, over the previous five years.

The second independent variable, economic activity (ECON), is based on the state leading indexes that are produced by the Federal Bank of Philadelphia. State leading indexes serve as a six-month outlook of local economic conditions. The state leading indexes for each state are similar to the Leading Index for the U. S., which relies on multiple economic indicators to capture economic trends (Puenpatom \& Stark, 2016). The leading indexes provide a composite measure of national and local economic inputs (Puenpatom \& Stark, 2016). Higher 
index scores indicate better economic conditions and vice versa. Bagley et al. $(2016,4)$

explained that the Leading Index for the U. S. provided a "smoothing effect that avoids much of the volatility reflected in individual components." Similar to the Leading Index of the U. S., the state leading indexes are based on a coincident index for each state and are further adjusted with additional lead indicators that capture unique measures related to growth at the state level (e.g., housing permits, unemployment, manufacturing surveys by the Institute for Supply Management which monitors for changes to production). ${ }^{15}$ Puentpatom and Stark (2016) found that state leading indexes outperformed the national-level Leading Index for the U. S.

\subsubsection{Control variables}

Consistent with Apostolou et al. (2014), control variables fall into four major categories: the unassigned fund balance, bond characteristics, bond issuer characteristics, and yield curve attributes. Governmental accounting literature has provided evidence that a municipality's unassigned fund balance is significant to borrowing cost (e.g., Plummer et al., 2007; Apostolou et al., 2014; Reck \& Wilson, 2014). Unassigned fund balance represents the portion of total assets less total liabilities that is not subject to spending constraints. The unassigned fund balance is directly increased or decreased, based on SR deficits or SR surpluses for each accounting period. Consistent with prior research, I expect a negative association between unassigned fund balance and TIC.

Bond characteristics and issuer characteristics (e.g., maturity, issue amount, bond rating) are frequently included in estimations of borrowing cost. For this study, I use the same variables

\footnotetext{
${ }^{15}$ The coincident index is published monthly by the Federal Reserve Bank of Philadelphia. The coincident index consists of four indicators: nonfarm payroll employment, average hours worked in manufacturing, the unemployment rate, and wage salary disbursements deflated by the average CPI for the municipality. Estimation of each of these factors follows Stock \& Watson (1989). See https://www.philadelphiafed.org/research-and-data/regional-economy/indexes/coincident.
} 
specified by Apostolou et al. (2014). Proxies for the yield curve include alternative measures of the federal funds rate (LEVEL). The federal funds rate is the interest rate that is established among lending institutions that maintain deposits at Federal Reserve banks. The federal funds rate provides a direct and non-biased estimation of interest rate levels in the municipal bond market (Apostolou et al., 2014). A higher federal funds rate indicates higher cost for borrowing in the overall market. Importantly, Bernanke and Blinder (1992) conclude that the federal funds rate provides comparatively better information content for the movement of real macroeconomic variables at the national level. Specifically, the federal funds rate does not suffer from the same level of endogeneity with contemporaneous economic conditions, as do other measures of interest rate levels (Bernanke and Blinder, 1992). To account for the effects of quantitative easing by the Federal Reserve Board, I estimate TIC with a combination of the federal funds rate and the "shadow" federal funds rate that were provided by the Federal Reserve Bank of Atlanta and estimated with models developed by Wu \& Xia (2016). Variable descriptions are summarized in Table 2.

[insert Table 2 here]

\subsection{Empirical model and specifications}

I extend from the OLS model specified by Apostolou et al. (2014), which estimated TIC as a function of SR, bond and issuer characteristics, and yield curve attributes. ${ }^{16}$ Exact model

\footnotetext{
${ }^{16}$ A partial replication of Apostolou et al. (2014) was conducted to determine the extendibility of the authors' findings for the financial crisis and recovery years (2007-2014). Overall, replication results showed that their findings are largely replicable for linear estimations of SR, and that these findings are extendible into longer time horizons (i.e., 1995-2014). Accordingly, all hypothesis tests for this study were based only on linear estimations of SR. While the nonlinear properties of SR may be worthy of further exploration, inclusion of nonlinear estimates for this study was not essential for the stated research objectives. Based on replication results, I also deviated from Apostolou et al. (2014) and used a stronger transformation for the CURVE control variable, computed as the inverse of years to maturity.
} 
specifications for hypothesis tests and research questions are discussed in the next sections. The OLS regressions for this study follow the general form:

Borrowing cost $=f$ (spending rate, economic activity, interaction terms, control variables)

Application of fixed effects is applied across model specifications for all hypothesis tests to correct for statistical dependence in repeated observations and to reduce the possibility of omitted variable bias. ${ }^{17}$ In their empirical models, Apostolou et al. (2014) restricted SR to capture the change in slope at SR equilibrium (i.e., nonmonotonicity). Specifically, any departure from SR equilibrium was constrained so that the regression coefficient for SR was forced to take a positive or negative sign, regardless of whether SR was a deficit or surplus. I maintained this restriction for H1, H2, and H3. Tests for SR volatility (RQ1 and RQ2) requires the use of an unrestricted model to effectively compare SR (level) with SR volatility measures. Control variables remain the same throughout all testing.

\subsubsection{Specification for $\mathrm{H} 1$}

H1 tests whether economic activity moderates the SR-TIC association. For this hypothesis, two variables are added to Apostolou et al.'s (2014) base model. The first variable, ECON, captures variations in economic activity. The second variable is an interaction term that captures the moderating effect of economic activity on the SR-TIC association. I expect a statistically significant coefficient (i.e., a p-value $<0.050$ ) for the interaction between SR magnitude and ECON. The model for $\mathrm{H} 1$ is specified:

\footnotetext{
${ }^{17}$ Consistent with Apostolou et al. (2014), I apply fixed effects in OLS regress regressions. Replication results were optimal when county-level fixed effects were removed and replaced with state-level fixed effects. Based on the replication results, I rationalize that county-reported SR may not change considerably from one period to the next and thus, the application of county-level fixed effects might have been too restrictive and eliminated substantial variations in SR. Thus, I re-specified Apostolou et al.'s (2014) models with state-level fixed effects; this approach eliminated within-entity variation among the individual entities while preserving variation in the SR measures that were reported by counties.
} 


$$
\begin{aligned}
\mathrm{TIC}_{\mathrm{it}}=\beta_{0} & +\beta_{1} \mathrm{SR}_{\mathrm{it}}+\beta_{2} \mathrm{ECON}_{\mathrm{jt}}+\beta_{3} \mathrm{SR} 1_{\mathrm{it}} \times \mathrm{ECON}_{\mathrm{jt}}+\beta_{4} \mathrm{FB}_{\mathrm{it}}+\beta_{5} \mathrm{SLOPE}_{\mathrm{it}}+\beta_{6} \mathrm{CURVE}_{\mathrm{it}} \\
& +\beta_{7} \mathrm{LEVEL}_{\mathrm{t}}+\beta_{8} \mathrm{AMT}_{\mathrm{it}}+\beta_{9} \mathrm{BID}_{\mathrm{it}}+\beta_{10} \mathrm{BR}_{\mathrm{it}}+\beta_{11} \mathrm{CALL}_{\mathrm{it}}+\beta_{12} \mathrm{FE}_{\mathrm{j}}+\varepsilon_{\mathrm{it}}
\end{aligned}
$$

Independent variables

$\begin{array}{ll}\text { SR1 } & =\text { absolute value of total revenues less total expenditures, divided by population } \\ \text { ECON } & =\text { the leading index for state(j) of county(i), in the same month of the bond issue } \\ \text { SR1×ECON } & =\text { interaction of SR1 and economic activity } \\ \text { Control variables } \\ \begin{array}{ll}\text { FB } & =\text { total unassigned fund balance divided by population } \\ \text { SLOPE } & =\text { average maturity of the bond issue in years } \\ \text { CURVE } & =\text { the inverse of the average maturity of the bond issue in years (i.e., } 1 \text { SLOPE) } \\ \text { LEVEL } & =\text { the combination of the effective federal funds rate (1995-2008) and the } \\ & \text { shadow federal funds rate (2009-2014), for the same month of the bond issue } \\ \text { AMT } & =\text { natural log the maturity value of the bond issue scaled by population } \\ \text { BID } & =\text { binary variable coded } 1 \text { if the bond was competitively bid; otherwise } 0 \\ \text { BR } & =\text { binary variable coded } 1 \text { if the bond rating is Aaa; otherwise } 0 \\ \text { CALL } & =\text { binary variable coded } 1 \text { if the bond is callable; otherwise } 0 \\ \text { FE } & =\text { estimated state fixed effects }\end{array}\end{array}$

\subsubsection{Specification for $\mathrm{H} 2$ and $\mathrm{H} 3$}

H2 and H3 are tested together. Like H1, I introduce variables for SR deficits (SRD) and SR surpluses (SRS), and corresponding interaction terms (SRD $\times E C O N$ and SRS $\times E C O N) . \quad H 2$ and H3 each predict different moderating effects of economic activity on the SR-TIC relationship for deficits and surpluses, respectively. For H2, I expect a positive coefficient for the interaction term, $\mathrm{SRD} \times \mathrm{ECON}$ (i.e., $\beta_{4}$ ). For H3, I expect a negative coefficient for the interaction term, $\mathrm{SRS} \times \mathrm{ECON}$ (i.e., $\beta_{5}$ ). Equation 2 is specified as follows:

$$
\begin{aligned}
\mathrm{TIC}_{\mathrm{it}}=\beta_{0} & +\beta_{1} \mathrm{SRD}_{\mathrm{it}}+\beta_{2} \mathrm{SRS}_{\mathrm{it}}+\beta_{3} \mathrm{ECON}_{\mathrm{jt}}+\beta_{4} \mathrm{SRD}_{\mathrm{it}} \times \mathrm{ECON}_{\mathrm{jt}}+\beta_{5} \mathrm{SRS}_{\mathrm{it}} \times \mathrm{ECON}_{\mathrm{jt}} \\
& +\sum \beta_{6-14} \text { control variables }+\varepsilon_{\mathrm{it}}
\end{aligned}
$$

Independent variables

$\begin{array}{ll}\mathrm{SRD} & =\text { absolute value of SR deficit (revenues }<\text { expenditures) divided by population } \\ \mathrm{SRS} & =\text { absolute value of SR surplus (revenues }>\text { expenditures) divided by population } \\ \mathrm{ECON} & =\text { the leading index for state }(\mathrm{j}) \text { of county }(\mathrm{i}), \text { in the same month of the bond issue } \\ \mathrm{SRD} \times \mathrm{ECON} & =\text { interaction of SRD and economic activity } \\ \mathrm{SRS} \times \mathrm{ECON} & =\text { interaction of SRS and economic activity }\end{array}$




\subsubsection{Specification for RQ1 and RQ2}

RQ1 explores SR volatility (SRVOL) and its association to TIC. To estimate SRVOL, I follow Gore (2009) and compute the coefficient of variation of SR as the ratio of the standard deviation of SR to the mean of SR, over the previous five years.

To make comparisons between SR (level) and SR volatility, the model is estimated without any constraints (i.e., an unrestricted model). For RQ1, I replace SR (level) with SR volatility (SRVOL). Although I do not make a directional prediction, I expect a positive coefficient for SRVOL (i.e., $\beta_{1}$ ). For RQ2, I further include the interaction term (SRVOL $\times E C O N)$ to test whether economic activity moderates the association between SRVOL and TIC. I expect this association to be more severe during poor economic conditions (i.e., $\beta_{3}$ in model 3b should be positive). The models for RQ1 and RQ2 are specified in Equations 3a and 3b, respectively: ${ }^{18}$

$$
\begin{aligned}
\mathrm{TIC}_{\mathrm{it}}=\beta_{0} & +\beta_{1} \mathrm{SRVOL}_{\mathrm{it}-5}+\beta_{2} \mathrm{ECON}_{\mathrm{jt}}+\sum \beta_{3-11} \text { control variables }+\varepsilon_{\mathrm{it}} \\
\mathrm{TIC}_{\mathrm{it}}=\beta_{0} & +\beta_{1} \text { SRVOL Lit-5 }+\beta_{2} \mathrm{ECON}_{\mathrm{jt}}+\beta_{3} \mathrm{SRVOL}_{\mathrm{it}} \times \mathrm{ECON}_{\mathrm{jt}} \\
& +\sum \beta_{4-12} \text { control variables }+\varepsilon_{\mathrm{it}}
\end{aligned}
$$

Independent variables

SRVOL = coefficent variation of SR over the previous five years

ECON = the leading index for state(j) of county(i), in the same month of the bond issue SRVOL $\times E C O N=$ interaction of SR volatility and economic activity

Table 3 summarizes the tests, variables, and expectations of the study.

[insert Table 3 here]

\subsection{Data and sample selection}

The sample consisted of GO bond issues by U. S. counties from 1995 through 2014. GO bonds issues are ideal for this study because they are backed by the "full faith and credit" of the

\footnotetext{
${ }^{18}$ Clustering by counties is used in lieu of fixed effects.
} 
municipality's taxing power, rather than by a particular revenue stream (Apostolou et al., 2014; Seymour, 2014). Relative to other types of municipal bonds, GO bonds also largely reflect market interest rates (Reck \& Wilson, 2014).

Four separate databases are used to create the sample. Information on GO bond characteristics and related borrowing cost are from the Securities Data Company's (SDC) Platinum Database maintained by Thomson Reuters Financial Services. SDC Platinum is a comprehensive, online database that has facilitated a plethora of academic and practitioner-based financial research (e.g., SEC 2012; Apostolou et al., 2014). The SDC Platinum database is also recommended by the American Accounting Association (AAA) as a reliable source for research data on new municipal bond issues. ${ }^{19}$ Reported accounting information for SR and general fund balances are from the financial indicators database maintained by the Government Finance Officers Association (GFOA). The GFOA compiles accounting information from the audited annual financial reports (i.e., CAFRs) of governmental entities. Prior research has shown that differences in the quality of financial reporting among local governments have significant effects on borrowing cost and bond ratings (Baber \& Gore, 2008; Henke and Maher, 2016). Thus, I control for heterogeneity in financial reporting quality by only using accounting information from CAFRs that are awarded the GFOA's Certificate of Achievement for Excellence in Accountability Reporting (CAEAR). Data for yield curve attributes consists of combining data from SDC platinum for bond maturity information and from the Federal Reserve Bank of Atlanta for the federal funds rate.

State leading indexes are gathered from the Federal Reserve Bank of Philadelphia. McDonald III (2015) highlights that county governments are commonly considered the

\footnotetext{
${ }^{19}$ http://aaahq.org/GNP/Research/GNP-Data-Sources
} 
"administrative units of the state" and thus, are subject to state mandates on the provision of public services. As compared to cities or towns, this distinctive function placed on county governments makes them relatively more dependent on intergovernmental revenues from the state and potentially more susceptible to changes in state economies (McDonald III, 2015). Given the focus on county GO bonds and county-reported SR, the use of state leading economic indexes is relevant.

The sample selection is summarized in Table 4. I extracted 17,001 observations from SDC Platinum that consisted of GO bond issues which were issued by primary county governments. From this data, I eliminated 12,638 observations that did not have an observation for TIC. Preparation of CAFR data required hand validation of general fund revenue and expenditure values among 34 county CAFRs. No CAFR observations were eliminated from this process. After merging GO bond data with CAFR data, the sample was reduced to 1,970 observations.

\section{[insert Table 4 here]}

Table 5 provides a closer look at the distribution of the sample by state. Per Table 5 , new GO bonds were issued by 294 counties among 36 states. Six states (Maryland, Wisconsin, North Carolina, Michigan, Minnesota, Texas) account for approximately half (50.31\%) of the sample. Notably, a larger number of bonds were not necessarily issued by a larger number of counties. For example, only two counties (Clark and Washoe counties in Nevada) account for 3.96\% $(n=78)$ of the full sample. In contrast, 17 counties in California issued $n=46$ bonds, which equates to approximately 2.7 bond issues per county (41 issues/17 counties) over the sample period for California.

[insert Table 5 here] 
Tables 6 and 7 provide sample distributions by year and economic time periods, respectively. Per Table 6, the largest percentage (8.58\%) of bond issues were issued in the year 2010. In contrast, the smallest number of bond issues were issued in the year 1995 (1.73\%). Consistent with Pew (2016b), a noticeably fewer number of new GO bonds ( $n=99)$ were issued in the year 2008, as compared to the follow-on recovery years. In Table 7, determination of the relevant dates for the economic periods (pre-financial crisis, financial crisis, recovery) are in accordance with the National Bureau of Economic Research (NBER). ${ }^{20}$ The majority of the sample (55.7\%) was from the pre-financial crisis period, followed by the recovery period (35.55\%). New GO bonds issued during the financial crisis period make up only $8.93 \%$ of the sample and are smaller in total size of $\$ 7.16$ million, as compared to $\$ 39.6$ million in the prefinancial period and $\$ 26.5$ million in the recovery period.

[insert Table 6 and Table 7 here]

${ }^{20}$ See http://www.nber.org/cycles.html. 


\section{Analysis}

This section reports the summary statistics and the main results. Two steps were necessary before hypothesis testing was conducted: (1) check of the appropriateness of the data against normality assumptions, and (2) validate the extendibility of Apostolou et al.'s (2014) findings into the financial crisis and recovery years via replication. Results of a post hoc analysis related to RQ1 and RQ2 are also reported.

\subsection{Descriptive statistics}

Descriptive statistics are presented in Table 8. Over the sample period, the average TIC was $3.640 \%$ and ranged between $0.120 \%$ and $7.160 \%$. Average SR was $\$ 87.0$ per capita. The highest SR deficit level was -\$425.0 per capita (King County, WA in 1997) and the highest SR surplus level was at \$1,394.0 per capita (Fairfax County, VA in 2001). ${ }^{21}$ The sample largely consisted of observations with SR surpluses ( $80.3 \%, n=1,581)$, as compared to SR deficits $(19.7 \%, n=389)$. The average state leading index $(\mathrm{ECON})$ was 0.978 and varied between -8.204 (Genesee County, MI in 2008) and 5.233 (Clark County, NV in 2003). The average population was 551,296 with $97.3 \%(n=1,916)$ of the sample representing counties that were classified as urban areas. ${ }^{22}$ The average level of reported unassigned fund balance (FB) was $\$ 86.0$ per capita. The years to maturity (SLOPE), a primary proxy for the yield curve, averaged 15.6 years. Other proxies for yield curve attributes (CURVE and LEVEL) averaged 0.120 and

\footnotetext{
${ }^{21}$ SR surpluses in the 95\% and above percentiles of the sample consist entirely of observations from three counties that surround the Washington D.C. metro area: Fairfax County and Loudon County in Virginia, and Montgomery County in Maryland. Per the U. S. Census Bureau, these counties are among the wealthiest counties in the U.S. based on median household income (https://www.census.gov/did/www/saipe/data/highlights/files/2015highlights.pdf).

${ }^{22}$ Counties with population of 50,000 or greater are considered urban areas (https://www.census.gov/geo/reference/urban-rural.html).
} 
1.901, respectively. ${ }^{23}$ The total amount of bond issues (AMT) averaged $\$ 37.2$ million. Other variables for bond characteristics (BID, BR, CALL) consisted of bonds that were competitively bid (94.6\%, $n=1,865)$, were rated “Aaa” per Moody’s ( $n=1,707)$, and were callable (86.7\%, $n$ $=1,449)$, respectively.

[insert Table 8 here]

Figure 1 shows the average trend of TIC, SR, and ECON across the sample period. Compared to TIC and ECON, SR was relatively stable and near zero across time. Average TIC shows a steady decrease from $5.09 \%$ in 1995 to $2.75 \%$ in 2014 . As expected, average ECON dipped below zero during periods of recession that followed the crash of the "dotcom" bubble in 2001 and the financial crisis in 2007. ${ }^{24}$ Figure 2 provides a closer examination of cross-sectional means for SR, SR surpluses (SRS), and SR deficits (SRD). Across the years, a major drop in SRS average occurred in the year 2002 and then leveled out. Interestingly, the highest average levels of SRD were associated with periods of growth in economic history versus periods of recession.

[insert Figures 1 and 2 here]

Gross et. al. (2012) reported that municipalities dipped into fund balances to make up year-end deficits. Figure 3 depicts the average trend of negative spending rates (i.e., SR deficits) versus the average trend of unassigned fund balance. Across the sample period, FB showed a steady increase with spikes in fund balance levels in the years after the financial crisis. In comparison, the overall trend of average deficits was steady and closer to a zero value across the sample period.

\footnotetext{
${ }^{23}$ The CURVE variable was transformed to the inverse of years to maturity (i.e., 1/SLOPE). Thus, an average value of 0.120 for the CURVE variable indicates that the interest rates across a range of shorter and longer maturities begins to vary at approximately 8.33 years.

${ }^{24} \mathrm{http} / / /$ www.nber.org/cycles.html
} 
[insert Figure 3 here]

Table 9 provides Pearson correlation values $(r)$ for the variables used in regressions. Values with correlation coefficients that are significant at the $5 \%$ level $(p<0.050)$ and greater than the absolute value of 0.50 (i.e., $|0.50|$ ) are in bold. TIC was positively correlated with SR at $0.189(p<0.001)$. TIC was also significantly correlated with SR magnitude (SR1) at $0.183(p<$ $0.001)$ and SRS at $0.189(p<0.001)$. SRD did not show a significant correlation with TIC at conventional levels but was relevant at $-0.038(p<0.100)$. SR volatility (SRVOL) was positively correlated with TIC at $0.068(p<0.050)$. The ECON variable was negatively correlated with TIC at $-0.065(p<0.050)$. The ECON variable was not significantly correlated with any of the level measures of SR (i.e., SR1, SRD, SRS), but was positively correlated with SRVOL at $0.068(p<0.050)$. Unassigned fund balance (FB) was negatively correlated with TIC at $-0.175(p<0.001)$. The yield curve attributes of SLOPE, CURVE, and LEVEL all show significant correlations $(p<0.001)$ with TIC at values of $0.515,-0.340$, and 0.672 , respectively. Among the variables for bond characteristics, the call provision (CALL) was positively correlated with TIC at $0.419(p<0.001)$, which is consistent with literature that callable bonds have higher borrowing cost. However, counter to literature was a positive and significant correlation between TIC and bond rating (BR) at $0.125(p<0.001)$.

[insert Table 9 here]

\subsection{Assessment of normality assumptions}

Given significant correlation among some of the variables, a check for multicollinearity was conducted by evaluating variation inflation factors (VIF). VIF scores near or above 10 indicate problems with multicollinearity in the model (Field and Miles, 2010). The highest VIF 
among all the variables is 2.18 for SLOPE. ${ }^{25}$ Overall, VIF analysis provides insufficient evidence that multicollinearity was a problem.

Graphical examination of TIC, SR, and ECON indicated the presence of non-normality in the raw data. The distribution of the dependent variable, TIC, appeared approximately symmetric with skewness equal to -0.554 and a kurtosis at 2.90 , which was near the conventional standard of 3.0. The SR distribution followed a leptokurtic profile that was positively skewed at 3.35 with excess kurtosis at 13.31. The ECON variable also followed a leptokurtic profile that was negatively skewed at -1.37 with excess kurtosis at 3.69 . To address non-normality in the raw data, hand validation of extreme outliers for TIC and SR was conducted to correct for skewness and kurtosis. ${ }^{26}$

A joint skewness/kurtosis test (Jarque-Bera) for normality was also conducted on the residuals from regression models. Results of the Jarque-Bera test $(p<0.001)$ were significant for the presence of non-normality in the residuals. ${ }^{27}$ However, graphical assessment of the residuals indicated a distribution that was closer to approximating a normal distribution for skewness at 0.40 . The kurtosis of the residuals, however, was still above conventional standards at 5.82, which is associated with lower power for hypothesis testing (Field and Miles, 2010). In sum, I considered the sample to be adequate for testing under parametric approaches, given hand validation of the outliers in the sample and given significant results from the partial replication.

\footnotetext{
${ }^{25}$ Reported VIF scores are those obtained prior to regressions with interaction terms, as the inclusion of products of SR (e.g., SRD×ECON) will introduce collinearity and thus, inflate VIF scores. I also evaluated VIF scores with interaction terms included for all regressions. The highest VIF was 4.13 for the SRD $\times$ ECON interaction and is below the cautionary value of 10 .

${ }^{26}$ To preserve the sample size, a review of 34 CAFRs and verification of corresponding population figures against Census Bureau estimates to validate and/or to correct outliers. Transformation of the data was also attempted but did not improve normality.

${ }^{27}$ Field and Miles (2010) recommend visual examination of distributions, along with quantitative testing of significance in nonnormality, for sample sizes greater than 200.
} 
Specifically, significant results from the replication demonstrated that the sample size of $n=$ 1,970 provided sufficient power for hypothesis testing.

Importantly, normality assumptions for the disturbance term were evaluated to assess whether errors in the data generating process were appropriate for hypothesis testing. Results of the Breusch-Pagan test for equality in the variances of the error term did not provide sufficient evidence to reject the null of homoscedasticity $(p=0.857)$. However, a general test for heteroskedasticity (White) in the error term was significant for heteroskedasticity $(p<0.001)$. Given the presence of heteroskedasticity, the application of robust standard errors in all regressions was used to relax the assumption of homogeneity in the error term. Lastly, consistent with Apostolou et al. (2014), the application of fixed effects was also applied to correct for statistical dependence among repeated observations by the same entities across the panel and to reduce the effects of unobserved, time-invariant variables. Results of the Hausman test $(p=0.001)$ confirmed the use of fixed effects over random effects.

\subsection{Results}

All models were estimated for the entire sample period (1995-2014). For H1, H2, H3, state fixed effects were applied to all OLS regressions.

\subsubsection{Test of $\mathrm{H1}$}

H1 tested whether economic activity at the state level moderated the association between SR magnitude (SR1) and TIC. No directional prediction was made. A statistically significant coefficient for the interaction term, SR1×ECON, provided evidence to reject the null that there is no moderating effect of economic activity (ECON) on the SR1-TIC association.

Table 10 (column 1) presents regression results that were first estimated without the SR1×ECON interaction. This initial estimation was necessary to validate that SR1 and ECON 
were individually associated with TIC, prior to interaction. Results of this first regression show that the overall model was significant $(p<0.001)$ with $71.7 \%$ of the within-variation explained. Consistent with Apostolou et al. (2014), SR1 was positively associated with TIC with an estimated coefficient of $0.248(p<0.010)$. ECON was estimated at $-0.052(p<0.010)$ and indicated a direct main effect on TIC.

H1 is supported. Regression results are reported in Table 10 (column 2). The overall model for H1 was significant ( $p<0.001$ ) with $71.8 \%$ of the within-variation explained. Regression results showed a positive and statistically significant coefficient for the interaction term, SR1×ECON $(0.155, p<0.010)$. The SR1 variable also became nonsignificant after interaction with ECON, which provides additional support that the association between SR and TIC depends on the level of economic activity.

The significance of the interaction term suggests that state economic activity (ECON) moderates the SR1-TIC association with an additive effect that makes the SR-TIC association more or less positive, depending on the value of the state leading index. Specifically, when economic condition is good (ECON > 0), the SR1-TIC association became more positive (i.e., higher borrowing cost). Conversely, when economic condition was bad (ECON $<0$ ), the SR1TIC association became less positive. Taken together, economic condition positively moderates departures from SR equilibrium (i.e., SR1), such that TIC is more severely assessed when economic condition is good (ECON > $)$ ), as compared to when economic condition is bad $(\mathrm{ECON}<0) .{ }^{28}$

\footnotetext{
${ }^{28}$ Additional estimation of TIC using binary measures for ECON also confirmed a strong positive interaction between SR1 and ECON. ECON was assigned a value of "1" if the state leading index was greater than zero, and “0” otherwise.
} 
The results for $\mathrm{H} 1$ also indicate that the level of TIC is influenced by the main effect of ECON. Regression results showed a negative association between ECON and TIC. Specifically, when ECON is zero, indicating no growth or decline in economic activity, there is no interaction with SR and thus, there is no interaction between SR1 and ECON. However, when economic condition is good (ECON > 0), a discount is imposed on TIC as a main effect. Conversely, when economic condition is bad (ECON < 0), a premium is imposed on TIC as a main effect.

$$
\text { [insert Table } 10 \text { here] }
$$

\subsubsection{Tests of $\mathrm{H} 2$ and $\mathrm{H} 3$}

H2 and H3 were jointly tested. Overall, these hypotheses tested for differential moderating effects when SR was bifurcated between SR surpluses (SRS) and SR deficits (SRD). The rationale for differential effects between SRS and SRD was based on the asymmetric associations between TIC and positive and negative SR, respectively (Apostolou et al., 2014); specifically, that SRD was assessed more severely on TIC. H2 predicted that economic activity (ECON) would positively moderate the SR-TIC association such that borrowing cost (TIC) would be higher when there is a deficit (SRD). A significant and positive coefficient for the SRD $\times$ ECON interaction term would support H2. Conversely, H3 predicted that economic activity (ECON) would negatively moderate the SR-TIC association, such that borrowing cost (TIC) would be lower when there is a surplus (SRS). A statistically significant and negative coefficient for the SRS×ECON interaction term would support H3.

Table 11 (column 1) reports the results for $\mathrm{H} 2$ and $\mathrm{H} 3$ without interaction terms. The same procedures for $\mathrm{H} 1$ were repeated for $\mathrm{H} 2$ and H3. Results for this first regression (Table 11, column 1) included ECON and but no interaction terms. Consistent with Apostolou et al. (2014), the coefficients for positive and negative SR magnitudes were both positively associated with 
TIC but unequal in their effects on TIC. Specifically, results for Table 11 (column 1) showed that SRD is $0.888(p<0.010)$ and the SRS coefficient was $0.247(p<0.010)$, which affirms an asymmetric association with TIC. Results also indicated that the ECON variable, estimated at $0.052(p<0.010)$, was negatively associated with TIC.

$\mathrm{H} 2$ is not supported. Although the overall model is significant $(p<0.001)$ with $71.9 \%$ of the variation explained, regression results in Table 11 (column 2) indicated that the interaction between SRD and ECON was nonsignificant. The interaction term, SRD $\times$ ECON, was suggestive that SRD had a relevant association with TIC at the $10 \%$ significance level. However, there is insufficient evidence to reject the null for $\mathrm{H} 2$.

H3 is not supported. Regression results in Table 11 (column 2) showed a positive and significant coefficient for the interaction term, $\operatorname{SRS} \times \operatorname{ECON}(0.153, p<0.010)$. The positive sign of the coefficient was counter to the prediction for $\mathrm{H} 3$, which postured a negative moderation by ECON on the SR-TIC association, such that there would be a favorable effect of SR surpluses on borrowing cost (i.e., less penalty on TIC). Similar to results in H1, SRS became nonsignificant once the interaction was introduced, providing evidence of a clear interaction between SRS and the ECON variable. Consistent with results for H1, the positive moderation indicates that departures from SR equilibrium for surpluses (SRS) are assessed more severely on TIC when the economic condition is favorable.

\section{[insert Table 11 here]}

\subsubsection{Effects of control variables}

Consistent with prior literature, conditioning on unassigned fund balance (FB) indicated that FB was significant and negatively associated to TIC. Results for H1 estimated a coefficient 
of $-0.872(p<0.100)$. Similarly, results for H2 and H3 showed a coefficient estimate of -0.915 $(p<0.010)$

Yield curve attributes across all models were significant. Comparison of column 2 for Table 10 and Table 11 show that the SLOPE variable was $0.055(p<0.010)$, indicating that bonds with longer maturities were exposed to greater risk and thus, have higher borrowing cost. As expected, the CURVE variable was $-0.544(p<0.050)$ for H1 and $-0.541(p<0.050)$ for H2 and H3. The negative sign for the CURVE variable indicated that the positive relation between TIC and years to maturity diminishes. Also, regressions for all hypotheses yielded a positive coefficient of $0.267(p<0.010)$ for the LEVEL variable, which proxied for the prevailing interest rate of the yield curve.

Bond rating (BR) was nonsignificant in all estimations. This result may have been attributed to difficulty among rating agencies to properly capture default risk during periods of economic instability. Other variables for bond characteristics showed that the amount of the bond issue (AMT) was negatively associated $(-0.052, p<0.010)$ with TIC. This is consistent with past research, which has found that larger bond issues are associated with lower borrowing cost (e.g., Simonsen and Robbins, 2002; Park et al., 2017). Also consistent with past research was the increase in borrowing cost given a call provision (Simonsen and Robbins, 2002). The CALL variable across all models showed a positive estimate of $0.373(p<0.010)$ for H1 and $0.374(p<0.010)$ for $\mathrm{H} 2$ and H3. The BID variable, which describes whether the bond sale was competitively sold, was negatively associated with TIC at estimates of $-0.152(p<0.100)$ for H1 and $-0.154(p<0.100)$ for $\mathrm{H} 2$ and H3. However, the coefficient estimates for the BID variable did not reach conventional levels of significance. 


\subsubsection{Additional analysis}

Given significant results for H3, a simple slopes analysis was conducted to decompose the interaction between SRS and ECON. To conduct this analysis, I evaluated how the slope of SRS on TIC changed when holding ECON constant at various levels. SRS values were evaluated at the mean and the first, second, and third standard deviations of SR magnitudes for the sample. The mean of SRS observations represented the closest value to SR equilibrium among SRS observations, while each increase in standard deviation represented a larger departure from the mean. Slopes were computed for TIC on SRS, for each 0.5 increment of ECON, ranging from -8.0 (near the lowest value in the sample) to +5.5 (near the highest value in the sample).

Table 12 reports the adjusted predictions for TIC on SR, for selected values of ECON between -2.0 through +2.0 . For each ECON value, the positive association between TIC and SRS magnitude was maintained. Specifically, borrowing cost increased as SRS departed from the point that was closest to SR equilibrium (i.e., $\mu$ ). However, the overall level of TIC differed, depending on whether ECON was positive or negative.

[insert Table 12 here]

\subsection{Tests of RQ1 and RQ2}

RQ1 and RQ2 explored whether SR volatility (SRVOL) was significant to estimating borrowing cost, and whether SRVOL was moderated by ECON, respectively. Before conducting the test for RQ1, the cross-sectional means of SR and its corresponding determinants (i.e., general fund revenues and general fund expenditures) were evaluated to get an overview of average trends across the sample period. Figure 4 shows that the average trend for SR was fairly stable relative to the average trend of its determinants. Figure 4 also depicts a gradual increase in 
the average trend of revenues and expenditures across the entire sample period, despite a relatively level profile for SR. Gross et al. (2012) reported that municipalities experienced a sharp decline in tax revenues because of the financial crisis and that this reduction prolonged the recovery period. Consistent with this report, Figure 4 shows a clear reduction in both the average trend of revenues and expenditures in the years following the financial crisis, starting in 2009 and through 2012.

\section{[insert Figure 4 here]}

Regression results for RQ1 are reported in Table 13. SRVOL was computed as the coefficient of variation of SR for the previous five years, starting with the year 2002 and through 2014. ${ }^{29}$ After computation of SRVOL, a sample size of $n=1,316$ remained. Table 13 (column 1) provides the results of a preliminary regression that was estimated with SRVOL and without the ECON variable. The overall model was significant $(p<0.001)$ with $71.0 \%$ of the variation explained. The coefficient for SRVOL was estimated at $0.009(p<0.050)$ and was positively associated with TIC. Although the coefficient for SRVOL showed significance at a conventional level, the value of the coefficient was indiscernible from zero. Combined, there was weak evidence that SRVOL is relevant to borrowing cost. ${ }^{30}$

\section{[insert Table 13 here]}

I also reestimated the previous regression and added the ECON variable. Table 13 (column 2) provides the estimates with both SRVOL and ECON included as test variables. The overall model remained significant $(p<0.001)$ with $61.9 \%$ of the variation explained. When the

\footnotetext{
${ }^{29}$ To amplify, SRVOL for 2002 (SRVOL 2002 ) was computed based on SR for years 1997 through 2002, SRVOL $_{2003}$ was computed based on SR for years 1998 through 2003, and so on.

${ }^{30}$ Gore (2009) found significance in revenue volatility. Accordingly, I separately tested whether the volatility of SR determinants (revenues and expenditures) were significant to explaining TIC. I did not find significance with either variable.
} 
ECON variable was added, SRVOL fell out of significance and the coefficient value remained near zero. The ECON variable was still negatively associated to TIC with a coefficient estimated at $-0.075(p<0.010)$. Per Table 9, ECON and SRVOL were negatively correlated at $-0.056(p<$ 0.050). Taken together, the combined effects of ECON and SRVOL on TIC were inconclusive. Given insignificant results for SRVOL, RQ2 was not testable.

Like the results for $\mathrm{H} 1, \mathrm{H} 2$, and $\mathrm{H} 3$, the control variables of $\mathrm{FB}$ and the yield curve attributes (SLOPE, CURVE, LEVEL) remained significant with signs in predicted directions. SLOPE showed a positive coefficient of $0.065(p<0.010)$ across both regressions. CURVE showed a negative coefficient of $-0.759(p<0.010$, column 1$)$ and $-0.725(p<0.010$, column 2$)$. The amount of the bond issue (AMT) was estimated at $-0.070(p<0.010$, column 1$)$ and -0.068 ( $p<0.010$, column 2). Both bond rating (BR) and the type of bond sale (BID) were nonsignificant in both regressions.

\subsection{Post hoc analysis for SR persistence}

Given inconclusive results for SRVOL, I explored whether the inverse of SR volatility, its persistence, was relevant to the pricing of TIC. Persistence is one of several proxies for earnings quality and is described as the sustainability of earnings (Dechow and Schrand, 2010). Hence, most corporate literature has been motivated by the assumption that a higher persistence in earnings is an indicator of better earnings quality (Dechow and Schrand, 2010).

\subsubsection{Theory and model specification for SR persistence}

Dichev and Tang (2009) provided a mathematical relationship between earnings volatility and persistence. Specifically, a persistence coefficient $\left(\gamma^{2}\right)$ can be estimated for the relative predictability of earnings by regressing current year earnings based on 1-year lagged earnings:

$$
\text { Earningst }=\alpha_{0}+\gamma \text { Earningst }-1+\varepsilon_{\mathrm{t}}
$$


Taking the variance for both sides of the previous equation and rearranging terms yields a persistence coefficient $\left(\gamma^{2}\right)$ that is equal to the R-squared of the previous regression.

$$
\gamma^{2}=1-\operatorname{Var}(\varepsilon) / \operatorname{Var}(\text { Earnings })
$$

Consistent with Dichev and Tang (2009), I assumed that the variance of earnings is stationary over time, given a one-year time horizon. I substituted SR as an earnings measure to estimate the persistence coefficient. An autoregressive regression of SR was estimated as a function of SR from the previous time period that did not exceed three years:

$$
\mathrm{SR}_{\mathrm{t}}=\alpha_{0}+\gamma \mathrm{SR}_{\mathrm{t}-3}+\varepsilon_{\mathrm{t}}
$$

The R-squared from the autoregressive regression yielded a persistence coefficient of $\gamma^{2}=0.439$

for the sample period. A higher value for $\gamma^{2}$ would indicate greater predictability of SR. With an estimate for SR persistence for the subsample, I extended from Apostolou et al.'s (2014) model to estimate TIC on SR persistence. ${ }^{31}$

$$
\begin{aligned}
\text { TIC }_{\mathrm{it}}=\beta_{0} & +\beta_{1} \text { SRPERSIST }_{\mathrm{it}}+\beta_{2} \mathrm{ECON}_{\mathrm{jt}}+\beta_{3} \mathrm{FB}_{\mathrm{it}}+\beta_{4} \mathrm{SLOPE}_{\mathrm{it}}+\beta_{5} \mathrm{CURVE}_{\mathrm{it}}+\beta_{6} \mathrm{LEVEL}_{\mathrm{t}} \\
& +\beta_{7} \mathrm{AMT}_{\mathrm{it}}+\beta_{8} \mathrm{BID}_{\mathrm{it}}+\beta_{9} \mathrm{BR}_{\mathrm{it}}+\beta_{10} \mathrm{CALL}_{\mathrm{it}}+\varepsilon_{\mathrm{it}}
\end{aligned}
$$

\subsubsection{Subsample selection}

To conduct an autoregressive regression for SR and to focus on years surrounding the financial crisis, I restricted the full sample to include observations from years 2005 through 2011; this timeframe is +/- three years of the Great Recession of 2008. Next, I kept only counties that issued GO bonds in the pre-financial, financial crisis, and recovery. If there were multiple GO bonds sold in the same year, I chose the bond with the highest TIC. This left me with a balanced sample of $n=150$ bonds issued by 50 counties in 17 states.

\footnotetext{
${ }^{31}$ Clustered by counties.
} 


\subsubsection{Test for SR persistence (post hoc)}

I made no prediction on the direction of the coefficient but expected that SRPERSIST would be negatively associated with TIC. Table 14 (column 1) reports the regression results for the estimation of TIC on SRPERSIST. All models were estimated with OLS with robust standard errors clustered on county. I explored the significance of SRPERSIST without fixed effects. Fixed effects can remove the effects of time-invariant influences, which may include the persistence of SR if it does not change much over time. Instead, I clustered by county to control for correlation in the error term within each county. The overall model was significant ( $p<$ 0.001) with $49.6 \%$ of the variance explained. The variable, SRPERSIST, was estimated at 2.252 $(p<0.010)$. This result was counterintuitive and suggests that borrowing cost increases as the relative predictability of SR increases. Unlike previous regressions, the control variables of unassigned fund balance (FB), the federal funds rate (LEVEL), and the callable provision on bonds (CALL) fell out of significance when SRPERSIST was introduced to the model. Yield curve attributes of SLOPE and CURVE were estimated at $0.056(p<0.010)$ and $-2.371(p<$ 0.010), respectively.

Next, I added the ECON variable to evaluate whether it was significant to explaining TIC in the presence of SRPERSIST. Regressions results are shown in Table 14 (column 2). As expected, ECON was negatively associated with TIC with an estimate of $-0.096(p<0.010)$. However, SRPERSIST fell out of significance when the ECON variable was added. Pairwise correlations indicated that SRPERSIST and ECON were negatively correlated at a value of $-0.657(p<0.010)$.

The control variables in Table 14 (column 2) showed that the CURVE variable, estimated at -2.090, dropped in significance $(p<0.050)$ when ECON was estimated with SRPERSIST in 
the model. Among the control variables for bond characteristics, only AMT remained significant and negatively associated with TIC at $-0.157(p<0.010)$.

[insert Table 14 here]

\subsection{Summary}

The moderating effect of economic activity on the association between SR magnitude and TIC was tested. Main empirical analysis consisted of three hypothesis tests. Among the hypotheses, H1 was supported. H2 was not supported. H3 was not supported but the results yielded a significant interaction between SR surpluses and economic activity that was counter to my prediction.

Results from H1 and H3 showed that departures from SR equilibrium (i.e., its magnitude) were positively moderated by economic activity. Fundamental to this finding was the positive interaction between SR magnitude and ECON. This finding suggests that while departures from SR equilibrium are penalized on TIC, the severity of the penalty is not constant and depends on whether aggregate conditions in the economy are good or bad. Specifically, when economic activity at the state level has a positive outlook, departures from SR equilibrium impose an additive (i.e., more severe) penalty on TIC.

The results for RQ1 and RQ2 did not provide sufficient evidence that the second moment of SR, its historic volatility, has information content that is associated with TIC. This result led to a post hoc analysis with a smaller subsample to examine whether the persistence of SR might be significant to TIC. Results were counter to expectations in that SR persistence was positively, vice negatively associated with TIC. However, the strength of this association was significant and the loss of significance to key control variables (e.g., unassigned fund balance, federal funds rate) suggest that SR persistence may capture similar effects from these control variables. 


\section{Discussion}

This study examined whether the information content of spending rate had differential effects on borrowing cost when state economic activity was considered. Spending rate is a modified accrual earnings measure computed as the difference between general fund revenues and general fund expenditures of a municipality. A narrow stream of governmental accounting literature that started from Wallace (1981) provided evidence that accounting measures related to the general fund (i.e, the primary operating fund) have information content. Since Wallace (1981), the literature has evolved and affirmed that the information content of spending rate is significantly associated to various responses in the municipal bond market (e.g., true interest cost, net interest cost, bond yield spreads).

Apostolou et al. (2014) demonstrated a positive association between departures from SR equilibrium (i.e., a balanced point where general revenues equal general fund expenditures) and borrowing cost. This positive association was significant irrespective of whether the departure from equilibrium was in the negative or positive direction. Their study resolved previous and conflicting findings regarding the association between spending rate and borrowing cost. Importantly, Apostolou et al.'s (2014) findings suggest that the market evaluates how well the reporting entity is able to balance its fiscal resources. Their findings imply that maintaining a spending rate at or near zero is one way to minimize borrowing cost.

Minimizing borrowing cost remains an important issue (Aguilar, 2015). Municipal bonds serve as a major source of financing for local governments to maintain critical infrastructure that can affect the quality of life of citizens (SEC, 2012; Aguilar, 2015). The importance of this market has been evidenced in its significant growth to approximately \$3.1 trillion (SEC, 2012; Aguilar, 2015). Furthermore, today’s municipal bond market has been characterized by greater 
regulatory oversight since the enactment of the Dodd-Frank Act in 2010. This has also led to greater scrutiny by the SEC to keep borrowing cost at a minimum (Ang and Green, 2011; Aguilar, 2015).

However, the ability of local government officials to maintain a close balance of revenues and expenditures may depend on the economic conditions to which they are subjected. Studies and reports surrounding the after-effects of the financial crisis that started in 2007 provided strong anecdotal evidence that maintaining a balance between revenues and expenditures (i.e., spending rate equilibrium) was difficult for many municipalities (Gross et al., 2012; Atwell et al., 2013). Most municipalities depended largely on property taxes as a major source of revenue and the collapse of the housing bubble led to widespread decline in property values. Concurrently, the financial crisis also weakened the states' abilities to provide aid to municipalities (Gross et al, 2012; Atwell et al., 2013).

In a recent study, Givoly et al. (2017) provided evidence that the role of accounting information in the debt market was conditioned on the macroeconomy. In their study, they focus on earnings information in the corporate sector and associated responses in the U. S. bond market. The authors' findings suggest that accounting numbers have greater relevance when the macroeconomy worsens. Accordingly, the unique challenges experienced by municipalities after the financial crisis, coupled with evidence provided by Givoly et al. (2017), motivated my empirical examination of whether the information content of spending rate is also dynamic to conditions of the local economy.

To accomplish the main research objective, I substantially extended from Apostolou et al. (2014) by incorporating the state leading indexes to proxy for local economic activity. The state leading indexes are compiled by the Federal Reserve Bank of Philadelphia and provide a 
composite and forward-looking measure of local economic condition based on multiple for inputs related to economic growth. The role of the state was highlighted as playing a crucial role to the recovery of municipalities after the financial crisis (Atwell et al., 2013). Thus, including an aggregate measure of state economies was particularly relevant to this study.

A precursor for this study was to identify a baseline empirical model that could estimate true interest cost as a function of governmental accounting information. Also, this model had to be adaptable to periods of economic instability, such as with the financial crisis that began in 2007. Much of the recent literature in government accounting employed the use of bond ratings, which are based on lagged information. The empirical models specified by Apostolou et al. (2014) divested from those models featured in conventional governmental accounting literature and well-proxied the contemporaneous interest rate environment with the effective federal funds rate, a key monetary-policy determinant. Specifically, Apostolou et al. (2014) estimated true interest cost as a function of spending rate magnitude, controlled on bond characteristics and yield curve attributes that proxied for the prevailing interest rates. The control variables for yield curve attributes made their models conducive to estimating borrowing cost during periods of extreme economic instability, whereby prevailing interest rates were unconventionally influenced by the Federal Reserve Bank (Wu and Xia, 2016).

A partial replication of Apostolou et al.’s (2014) study with additional observations from the financial crisis, recession, and recovery periods (late 2007 through 2014) verified the extendibility of Apostolou et al.’s (2014) findings. Specifically, the association between departures from spending rate equilibrium and borrowing cost remained positively associated across stable and unstable economic periods. Verification of this association allowed for the 
testing of three hypotheses on whether economic activity moderated the association between spending rate magnitude and borrowing cost.

The research method employed a sample of 1,970 general obligation bonds that were newly issued in the years 1995 through 2014. Issuers consisted of 294 counties among 36 states. Reported governmental accounting information used to compute spending rate was sourced from county Comprehensive Annual Financial Reports (CAFR) that followed standards set forth by the Governmental Accounting Standards Board (GASB) in Statement No. 34. ${ }^{32}$ Hypothesis testing was conducted through a series of ordinary least squares regressions with the application of fixed effects.

The first hypothesis predicted a significant interaction between spending rate magnitude and economic activity. The rationale for this hypothesis was drawn from the idea that the information content of earnings was negatively associated to gross domestic product (Givoly et al., 2017); this association indicated that earnings has greater information content when economic conditions worsen. Similarly, I extended on this rationale in the governmental setting to test whether spending rate magnitude had a significant interaction with economic activity. A significant interaction would indicate that the association between spending rate magnitude and borrowing cost depends on the level of economic activity.

Results of the first hypothesis provided the main finding for this study. I found a significant and positive interaction between spending rate magnitude and economic activity. A clear interaction was evident. Regression results revealed that the direct and positive effect of spending rate magnitude on true interest cost dissipated while the main effect of economic

\footnotetext{
${ }^{32}$ CAFRs used for this study received a mark of excellence in financial reporting based on requirements established by the Government Finance Officers Association (GFOA), a professional association that is not affiliated with GASB.
} 
activity remained negatively associated with true interest cost. Essentially, the main effect of economic activity was adjusted by the positive interaction between spending rate magnitude and economic activity. When economic activity was positive, the main effect of economic activity lowered borrowing cost but larger departures from spending rate equilibrium imposed a greater penalty on borrowing cost, as evidenced by the positive interaction. In contrast, when economic activity was negative, the main effect of economy activity increased borrowing cost. However, the interaction of negative economic activity and spending rate magnitude imposed a decrease on true interest cost, suggesting that larger departures from spending rate equilibrium were assessed less severely when the economic condition was unfavorable.

At the onset, this main finding may seem counterintuitive. In a study by Park et al., (2016), the authors similarly predicted increased salience in true interest cost during and after the financial crisis and found no support for greater penalty on true interest cost. This prediction is understandable, given significant findings in previous research that focus on the debt market’s sensitivity to downside risk in earnings (e.g., Plummer and Tse, 1999; Easton et al., 2009). However, my main finding makes sense when one considers Apostolou et al.’s (2014) suggestion that the market evaluates managerial competence over fiscal resources, relative to the benchmark of spending rate equilibrium.

Specifically, the positive interaction suggests that the ability of county officials to maintain spending rate equilibrium is assessed more severely when times are good in the economy. Put another way, maintaining a balance between revenues and expenditures during stable economic conditions is expected and failure to achieve this balance is, in the aggregate, unexpected. Thus, a larger departure from spending rate equilibrium during good economic times is contrary to the market's general expectations and influences a higher penalty on 
borrowing cost. In contrast, when there is a poor economy, the market's overall expectation of management's ability to balance revenues and expenditures is generally lower. Thus, the inability to maintain a balance between revenues and expenditures would not necessarily come as a surprise and thus, departures from spending rate equilibrium are imposed less severely during a poor economy.

Apostolou et al. (2014) found that the association between true interest cost and spending rate magnitude was asymmetric for positive (i.e., surplus) and negative (i.e., deficit) departures from spending rate equilibrium. Procedures from the first hypothesis test were repeated for hypotheses two and three. Separate test variables for the magnitudes of spending rate surpluses and deficits, and their respective interactions with economic activity, were added to the baseline model. Hypotheses two and three were jointly tested in one regression. Hypothesis two predicted that negative departures from spending rate equilibrium would be assessed more heavily on true interest cost when economic conditions are bad (i.e., economic activity is low).

Results for hypothesis two were not supported at a conventional level of significance. Spending rate magnitude for deficits were positively associated with borrowing cost and inclusion of its interaction with economic activity were suggestive of its relevance on borrowing cost. But there was insufficient evidence to reject the null. Two reasons might explain a null finding. First, the size of the magnitude of the deficits were approximately twelve times smaller than the magnitude of the surpluses. ${ }^{33}$ A second reason might be due to the significance of the unassigned fund balance. Apostolou $(1982,75)$ explained that a deficit in the general fund may be less important if the size of the fund balance is relatively large. The overall average trend of unassigned fund balance levels steadily increased over the sample period while deficits remained

\footnotetext{
33 Average magnitude of deficits and surpluses were 0.008 and 0.094 , respectively. Computation used was $0.094 / 0.008=11.75$.
} 
fairly level. Regressions results for hypothesis testing consistently indicated that conditioning on unassigned fund balance was significant to explaining borrowing cost. Combined, the interactive effect of economic activity and negative departures from spending rate equilibrium may have been negligible.

Hypothesis three predicted that positive departures from spending rate equilibrium would be associated with a discount on borrowing cost (i.e., a negative interaction term). This hypothesis was not supported. I obtained significant results for the interaction term that showed positive moderation. These results were counter to my prediction of a discount on borrowing cost for positive departures from spending rate equilibrium. This finding suggests that the market assesses the ability to balance revenues and expenditures, vice accumulate excess resources during times of economic instability. This finding reinforces the market's evaluation of managerial competence relative to a benchmark, which is consistent with Jiang (2008).

I also explored whether spending rate volatility was relevant to explaining borrowing cost. Significance in spending rate volatility would indicate that the second moment of spending rate has information content. In research question one, I tested for significance in the coefficient for spending rate volatility. Dichev and Tang (2009) explained that the historical volatility of earnings was related to economic factors when there is perfect matching between revenue and expenditures. Given a focus on economic activity across the financial crisis and recovery periods, I examined if these periods of extreme economic instability were captured in the historical volatility of spending rate. I estimated the historical volatility of spending rate by computing the coefficient of variation over the previous five years. ${ }^{34}$ Results of this test were inconclusive. While regression results provided a significant coefficient for spending rate

\footnotetext{
${ }^{34}$ Gore (2009) computed revenue volatility over four consecutive years using the coefficient of variation. I adopted the same approach to compute spending rate volatility over five years.
} 
volatility, the value of the coefficient itself was indiscernible from zero. Research question two was not testable given these results.

Although spending rate is a modified accruals measure, it may possess some properties that are similar to corporate earnings. Given inconclusive findings for spending rate volatility, I conducted a post hoc analysis to explore the significance of spending rate persistence and its association to borrowing cost. Persistence is a proxy for earnings quality (Dechow et al., 2010). The corporate literature provided evidence that the persistence of earnings is considered a positive attribute (Dechow et al., 2010). Dichev and Tang (2009) provided a mathematical derivation of persistence that defined persistence as the inverse of volatility. I rationalized that if the volatility of spending rate was not assimilated to borrowing cost, perhaps its persistence would be valued by the market. If so, this should result in a negative association between spending rate persistence and borrowing cost. Post hoc results indicated a strong and positive association between spending rate persistence and borrowing cost. Interestingly, the control variables of unassigned fund balance and the federal funds rate fell out of significance when spending rate persistence was added to the model. Also, when the variable for economic activity was included, spending rate persistence fell out of significance. Also unexpected was the positive coefficient for persistence. A possible explanation is that the model estimated the persistence of departures from spending rate equilibrium (a bad attribute), rather than what is understood in the corporate literature as the sustainability of future earnings (a good attribute). If this were the case, then a positive association is plausible.

\subsection{Implications and suggestions for future research}

As of date, no governmental accounting study has investigated the interactive effects of local economic activity and the information content spending rate. I extended the governmental 
accounting literature by providing preliminary evidence that the information content of spending rate is not constant and that information content is dynamic to the level of economic activity. Much of the recent governmental accounting literature focuses on the relevance of accrual based measures for government-wide reporting per GASB Statement No. 34 (e.g., Reck and Wilson, 2014; Ragland, 2017). The recent literature concluded that longer term accrual-based accounting measures provide incremental information only in the presence of modified accrual measures. The findings in this study suggest that the relevance of accrual-based measures may also depend on when the information content of spending rate is most relevant. Future research might benefit by examining accrual-based measures conditioned on economic activity.

Continuing from the previous point, the main finding also highlights the importance of state economies on the fiscal performance of municipalities and other local governments. This study has shown that the state leading indexes compiled by the Federal Reserve can serve as an important variable to proxy for local economic conditions. Streib, Svara, Waugh, and Klase (2007) stressed the importance of factoring in the impact of the state for research that involves county samples. The significance of the state leading indexes was consistent with this point. Thus far, no recent accounting literature has incorporated the state leading indexes compiled by the Federal Reserve. Including composite measures of local economic conditions may provide incremental information for a wide variety of accounting research.

The finding of a positive moderation from the interaction between spending rate magnitude and economic activity is of particular importance. As it pertains to responses in debt markets, the a priori expectation built upon the option framework is supported by strong evidence that responses in the debt markets are sensitive to downside risk in earnings. Givoly et al. (2017) note, however, that the option framework does not capture other relevant information 
that is available and/or disclosed to market participants. The predictions in this study were largely grounded in the literature that applied to the option framework. The overarching rationale was that spending rate represented an important measure of general fund performance and thus, the municipal bond market would also be sensitive to downside risk in spending rate. Specifically, given poor economic conditions from the financial crisis, I expected even larger departures from spending rate equilibrium. Furthermore, I expected these departures to be associated with harsher penalty on borrowing cost. However, the finding of a positive moderation is contrary to this expectation. Instead, this finding implies that the market assesses greater penalty on management's ability to balance revenues and expenditures when economic conditions are good. When economic conditions are bad, the market adjusts its expectations regarding management's ability to achieve balance. Thus, departures from spending rate equilibrium are assessed less severely when there is a poor economy. ${ }^{35}$

Fundamentally, it is not the spending rate measure itself that is being evaluated by the market. Rather, the market evaluates the managerial competence over spending rate, relative to a benchmark (i.e., spending rate equilibrium). Apostolou et al. (2014) demonstrated that keeping spending rate at or near zero is one way of minimizing borrowing cost. My findings are consistent with this notion and has practical implications for local managers to minimize borrowing cost. Future research might explore the incentives surrounding the importance of this benchmark and other potential consequences. This study suggests that maintaining the benchmark is beneficial for borrowing cost. However, Felix (2015) found that municipal

\footnotetext{
${ }^{35}$ Given the finding of a positive moderation between spending rate magnitude and economic activity, I explored additional literature related to economic condition and corporate earnings. Two earningsmanagement studies (Conrad, Cornell, and Landsman, 2002; Cohen and Zarowin, 2007) provided rationale that are consistent with my main finding. Future development of this study will need to build upon findings from Conrad et al. (2002) and Cohen and Zarowin (2007).
} 
managers excessively use inter-fund transfers to maintain a general fund balance near zero.

Costello et al. (2017) also provided evidence of "earnings management” at the state level intertemporally, which contradicts GASB Concept Statement No. 1. Whether these collective actions are beneficial for the long-term, economic well-being of the municipality is uncertain.

Exploring spending rate based on its volatility and persistence yielded significant (post hoc) results that may warrant further investigation. Little is known concerning the quality of spending rate and/or other similar performance measures in the governmental setting. The modified accrual basis of accounting makes spending rate a unique measure. Future studies might apply the earnings quality framework from corporate literature to investigate the extent to which spending rate mimics earnings behavior. Also, Dechow et al. (2010) identified determinants of earnings quality (e.g., governance, auditors, financial reporting practices, entitylevel characteristics). Examining how these determinants influence the quality of the spending rate may also be an avenue for future research.

\subsection{Limitations}

The interpretation of the findings is limited in two ways. First, the sample selection was strictly based on primary county governments that corresponded directly to the CAFR data. This decision was made to provide greater homogeneity in the sample. However, this also reduced the generalizability of the results to primary county governments. Also, as with many panel data, the sample was unbalanced and thus, further limits the findings to counties that make up most of the observations in the sample.

A second limitation involves greater regulatory oversight stemming from the Dodd-Frank Act of 2010. Given data limitations, I did not include control variable(s) to account for changes related to Dodd-Frank. One result that came from this legislation was a requirement for dealers 
to register with the Municipal Securities Rulemaking Board (MSRB) before engaging in municipal bond sales. ${ }^{36}$ Liu (2015) found that the familiarity between dealers (i.e., financial advisors) and issuers or underwriters, respectively, was associated with lower or higher borrowing cost for negotiated sales. Whether greater oversight affected the familiarity among these parties and/or other factors related to borrowing cost are yet to be fully understood.

\subsection{Conclusion}

Since Wallace (1981), research has provided evidence that spending rate has information content to various responses in the municipal bond market. Over the years, studies have produced mixed results on the association between spending rate and borrowing cost. Apostolou et al. (2014) clarified that the association is relative to a balanced point where revenues equal expenditures. Their finding implies that the market evaluates a municipality's ability to achieve this balance. In sum, spending rate is a proxy for managerial competence.

This study extended from Apostolou et al. (2014) and examined whether the information content of spending rate was influenced by the state's economy. My results provide preliminary evidence that the information content of spending rate is dynamic to levels of economic activity. Regression results clearly indicated that the association between spending rate magnitude and borrowing cost was positively moderated by economic activity. This suggests that the municipal bond market assesses departures from spending rate equilibrium more severely when economic conditions are favorable and less severely when economic conditions are unfavorable. On a practical basis, this finding suggests that achieving spending rate near zero may minimize borrowing cost. Lastly, the notion that information content of spending rate is dynamic to

\footnotetext{
${ }^{36}$ http://www.msrb.org/Regulated-Entities/MSRB-Registration.aspx
} 
economic activity might provide incremental benefit regarding the usefulness of other governmental accounting measures under the current financial reporting model. 


\section{References}

Aguilar, L. A. (2015). Statement on making the municipal securities market more transparent, liquid, and fair. Securities Exchange Commission (SEC).

$<$ https://www.sec.gov/news/statement/making-municipal-securities-market-moretransparent-liquid-fair.html>.

Ang, A., \& Green, R. C. (2011). Lowering borrowing costs for states and municipalities through CommonMuni. Washington D.C.: Brookings Institution.

$<$ https://www.brookings.edu/wpcontent/uploads/2016/07/02_municipal_bond_ang_green_paper.pdf>.

Apostolou, B., Apostolou, N., \& Dorminey, J. W. (2014). The association of departures from spending rate equilibrium to municipal borrowing cost. Advances in Accounting, 30(1), $1-8$.

Apostolou, N. (1982). An empirical evaluation of the relationship between accounting information and muncipal bond net interest cost. (Doctoral dissertation), 1-103.

Apostolou, N., Giroux, G., \& Welker, R. (1985). The information content of municipal spending rate data. Journal of Accounting Research, 23(2), 853-858.

Apostolou, N., Reeve, J., \& Giroux, G. (1984). Accounting information and municipal bond interest cost: An empirical evaluation. Journal of Accounting and Public Policy, 3(1), 9-28.

Arnold, P. (2009). Global financial crisis: The challenge to accounting research. Accounting, Organizations and Society, 34(6), 803-809.

Atwell, M. S., Fehr, S., Huh, K., \& Russell, A. (2013). The State role in local government financial distress. The Pew Charitable Trusts.

$<$ http://www.pewtrusts.org/ /media/assets/2013/07/23/pew_state_role_in_local_governm ent_financial_distress.pdf>.

Baber, W. R., Gore, A. K., Rich, K. T., \& Zhang, J. X. (2013). Accounting restatements, governance and municipal debt financing. Journal of Accounting and Economics, 56 (23), 212-227.

Baber, W. R., \& Gore, A. K. (2008). Consequences of GAAP disclosure regulation: Evidence from municipal debt issues. The Accounting Review, 83(3), 565-591.

Bagley, P., Dorminey, J. W., McSwain, D., \& Reed, T. (2016). Managing risk in a poor economy: The association between economic activity and auditor response to risk. Advances in Accounting, 32 (March 2016), 1-9. 
Ball, R., \& Brown, P. (1968). An empirical evaluation of accounting income numbers. Journal of Accounting Research, 6(2), 159-177.

Barr, C. (2015). The new bond market: Bigger, riskier, and more fragile than ever; Gigantic debttrading arena is subject as never before to price reversals and disruptions. Wall Street Journal (online). October 05.

Bernanke, B., \& Blinder, A. (1992). The federal funds rate an the channels of monetary transmission. American Economic Review, 82(4), 901-921.

Bharath, S. T., Sunder, J., \& Sunder, S. V. (2008). Accounting quality and debt contracting. The Accounting Review, 83(1), 1-28.

Black, F., \& Scholes, M. (1973). The pricing of options and corporate liabilities. Journal of political economy, 81(3), 637-654.

Callahan, C. M., \& Waymire, T. R. (2015). The GASB No. 34 impact to budget-to-actual variances on bond ratings: evidence from U.S. cities. Journal of Governmental \& Nonprofit Accounting, 4(1), 32-52.

Carroll, D. A. (2009). Diversifying municipal government revenue structures: Fiscal illustion or instability? Public Budgeting \& Finance, 29(1), 27- 48.

Cheng M., \& Neamtiu, M. (2009). An empirical analysis of changes in credit rating properties: Timeliness, accuracy and volatility. Journal of Accounting and Economics, 47(1), 108130.

Cohen, D., \& Zarowin, P. (2007). Earnings management over the business cycle. $<$ http://web-docs.stern.nyu.edu/old_web/emplibrary/EM_08_23_07FINAL.pdf>.

Conrad, J., Cornell, B., \& Landsman, W. R. (2002). When is bad news really bad news? Journal of Finance, 57(6), 2507-2532.

Copeland, R. M., \& Ingram, R. W. (1982). The association between municipal accounting information and bond rating changes. Journal of Accounting Research, 20(2, Part I), 275289.

Costello, A. M., Petacchi, R., \& Weber, J. (2017). The impact of balanced budget restrictions on States' fiscal actions. The Accounting Review, 92(1), 51-71.

Crone, T. (2000). A new look at economic indexes for the states in the third district. Federal Reserve Bank of Philadelphia. <https://philadelphiafed.org/-/media/research-anddata/publications/business-review/2000/november-december/brnd00tc.pdf>.

Dechow, P. M., \& Dichev, I. D. (2002). The quality of accruals and earnings: The role of accrual estimation errors. The Accounting Review, 77 (Supplement), 35-59. 
Dechow P., Ge W., \& Schrand, C. (2010). Understanding earnings quality: A review of the proxies, their determinants and their consequences. Journal of Accounting and Economics, 50(2), 344-401.

DeFond, M., \& Zhang, J. (2014). The timeliness of the bond market reaction to bad earnings news. Contemporary Accounting Research, 31(3), 911-936.

deHaan, E. (2016). The financial crisis and corporate credit ratings. The Accounting Review, doi: 10.2308/accr-51659.

Dichev, I. D., \& Tang, V. W. (2008). Matching and the changing properties of accounting earnings the last 40 years. The Accounting Review, 83(6), 1425-1460.

Dichev, I. D., \& Tang, V. W. (2009). Earnings volatility and earnings predictability. Journal of Accounting and Economics, 47(1-2), 160-181.

Easton, P. D., Monahan, S. J., \& Vasvari, F. P. (2009). Initial evidence on the role of accounting earnings in the bond market. Journal of Accounting Research, 47(3), 721-766.

Erickson, D., Hewitt, M., \& Maines, L. A. (2017). Do investors perceive low risk when earnings are smooth relative to the volatility of operating cash flows? Discerning opportunity and incentive to report smooth earnings. The Accounting Review, 92(3), 137-154.

Federal Reserve. (2016). Federal Reserve Statistical Release: Financial Accounts of the United States, Third Quarter 2016. <https://www.federalreserve.gov/releases/z1/current/z1.pdf>.

Felix, R. (2015). The use of inter-fund transfers to manage the 'bottom line' in the municipal context. Journal of Governmental \& Nonprofit Accounting, 4(1), 17-31.

Field, A. \& Miles, J. (2010). Discovering Statistics Using SAS. London, UK: Sage Publications, Ltd.

Givoly, D., Hayn, C., \& Katz, S. (2017). The changing relevance of accounting information to debt holders over time. Review of Accounting Studies, 22(1), 64-108.

Gkougkousi, X. (2014). Aggregate earnings and corporate bond markets. Journal of Accounting Research, 52(1), 75-106.

Gore, A. K. (2009). Why do cities hoard cash? Determinants and implications of municipal cash holdings. The Accounting Review, 84(1), 183-207.

Governmental Accounting Standards Board (GASB). (1987). GASB Concepts Statement No.1 objectives of financial reporting.

$<$ http://www.gasb.org/jsp/GASB/Document_C/GASBDocumentPage?cid=11761600398 64\&acceptedDisclaimer=true $>$. 
Governmental Accounting Standards Board (GASB). (1990). Summary of Statement No.11 Measurement focus and basis of accounting - governmental fund operating statements. $<$ http://www.gasb.org/st/summary/gstsm11.html $>$.

Governmental Accounting Standards Board. (1998). Statement No.33 of the Governmental Accounting Standards Board - Accounting for financial reporting and nonexchange transactions.

$<$ http://www.gasb.org/cs/BlobServer?blobkey=id\&blobwhere=1175824063588\&blobhea der=application\%2Fpdf\&blobcol=urldata\&blobtable=MungoBlobs>.

Governmental Accounting Standards Board (GASB). (1999). Statement No. 34 of the Governmental Accounting Standards Board - Basic financial statements and management's discussion and analysis for state and local governments. $<$ http://www.gasb.org/st/summary/gstsm34.html>.

Governmental Accounting Standards Board (GASB). (2011). The timeliness of financial reporting by state and local governments compared with the needs of users. $<$ http://www.gasb.org/cs/BlobServer?blobkey=id\&blobwhere=1175822186092\&blobhea der=application\%2Fpdf\&blobcol=urldata\&blobtable=MungoBlobs $>$.

Governmental Accounting Standards Board (GASB). (2012). Basic facts about GASB's project on economic condition reporting: fiscal sustainability. $<$ http://www.gasb.org/cs/ContentServer?c=Document_C\&pagename=GASB/Document_ C/GASBDocumentPage\&cid=1176156740802>.

Government Finance Officers Association (GFOA). (1994). Competitive v. negotiated - how to choose the method of sale for tax-exempt bonds.

$<$ http://www.gfoa.org/sites/default/files/APractitionersGuideCompetitiveVs Negotiated.pdf $>$.

Graham J. R., Harvey, C. R., \& Rajgopal, S. (2005). The economic implications of corporate financial reporting. Journal of Accounting and Economics, 40(1-3), 3-73.

Gross, L., Huh, K., Sylvester, A., \& Zahradnik, R. (2012). The local squeeze. The Pew Charitable Trusts. <http://www.pewtrusts.org/en/research-andanalysis/reports/0001/01/01/the-local-squeeze $>$.

Hendrick, R. (2006). The role of slack in local government finances. Public Budgeting \& Finance, 21(1), 14-46.

Henke, T. S., \& Maher, J. J. (2016). Government reporting timeliness and municipal credit market implications. Journal of Governmental \& Nonprofit Accounting, 5(1), 1-24.

Ingram, R. W. \& Copeland, R. M. (1982). Municipal market measures and reporting practices: An extension. Journal of Accounting Research, 20(1, Part II), 766-772. 
Istrate, E. (2013). Municipal Bonds Build America. National Association of Counties (NACO). $<$ http://www.naco.org/sites/default/files/NACoResearch_Policy_MuniBonds_2013_0.pdf>.

Jiang, J. X. (2008). Beating earnings benchmarks and cost of debt. The Accounting Review, 83(2), 377-416.

Kothari, S. P., \& Lester, R. (2012). The role of accounting in the financial crisis: lessons for the future. Accounting Horizons, 26(2), 335-351.

Kothari, S. P., Ramanna, K., \& Skinner, D. J. (2010). Implications for GAAP from an analysis of positive research in accounting. Journal of Accounting and Economics, 50(2), 246-286.

Kraft, P. (2015). Rating agency adjustments to GAAP financial statements and their effect on ratings and credit spreads. The Accounting Review, 90(2), 641-674.

Liu, G. (2015). Relationships between financial advisors, issuers, and underwriters and the pricing of municipal bonds. Municipal Finance Journal, 36(1), 1-25.

McDonald III, B. D. (2015). Does the charter form improve the fiscal health of counties? Public Administration Review, 75(4), 609-618.

Miranda, R. A., \& Picur, R. D. (2000). Benchmarking and measuring debt capacity. Government Finance Officers Association. $<$ http://www.gfoa.org/sites/default/files/RecommendedBudgetPractices.pdf $>$.

Park, K. O. (1996). Determinants of county government growth. In D. C. Menzel, The American County: Frontiers of Knowledge (pp. 81-91). Tuscaloosa, Alabama: The University of Alabama Press.

Park, Y. J., Matkin, D. S., \& Marlowe, J. (2017). Internal control deficiencies and municipal borrowing costs. Public Budgeting \& Finance 37(1), 88-111.

Pew Charitable Trusts. (2016a). Fiscal health of large U. S. cities varied long after Great Recession's end. <http://www.pewtrusts.org/en/research-and-analysis/issuebriefs/2016/04/fiscal-health-of-large-us-cities-varied-long-after-great-recessions-end>.

Pew Charitable Trusts. (2016b). Issuance of new money bonds remains low in large U. S. cities. $<$ http://www.pewtrusts.org/en/research-and-analysis/issue-briefs/2016/04/issuance-ofnew-money-bonds-remains-low-in-large-us-cities>.

Plummer, E. C., \& Tse, S. Y. (1999). The effect of limited liability on the informativeness of earnings: Evidence from the stock and bond markets. Contemporary Accounting Research, 16(3), 541-574. 
Plummer, E., Hutchinson, P. D., \& Patton, T. K. (2007). GASB No.34's Governmental financial reporting model: Evidence on its information relevance. The Accounting Review, 82(1), 205-240.

Praagh, A. V., \& Dorer, J. (2010). Recalibration of Moody's U. S. municipal ratings to its global rating scale. Moody's. <http://investorrelations.hawaii.gov/dhhl/wpcontent/uploads/sites/4/2014/02/Moody_Rating_Implementation_Guidance.pdf>.

Pridgen, A. K., \& Wilder, W. M. (2013). Relevance of GASB No. 34 to financial reporting by municipal governments. Accounting Horizons, 27(2), 175-204.

PricewaterhouseCoopers (PwC). (2014). The municipal securities market-greater transparency and comparability of financial information would benefit stakeholders. $<$ http://www.pwc.com/us/en/cfodirect/.../point-of-view/municipal-securitiesmarket.html>.

Puenpatom, T., \& Stark, T. (2016). Do state indicators trump national ones for predicting economic activity in the states? The case of New York. Federal Reserve Bank of Philadelphia. <https://www.philadelphiafed.org/-/media/research-anddata/publications/research-brief/rb-20161025.pdf?la=en>.

Ragland, L. (2017). The association between compensated absences liabilities and interest cost on public school districts’ general obligation bonds. Accounting Horizons, 31(1), 37-55.

Reck, J. L., \& Wilson, E. R. (2014). The relative influence of fund-based and government-wide financial information on municipal bond borrowing costs. Journal of Governmental and Nonprofit Accounting, 3(1), 35-57.

Securities Exchange Commission (SEC). (2012). Report on the municipal securites market. Securities Exchange Commission. <https://www.sec.gov/news/studies/2012/munireport073112.pdf>.

Seymour, D. (2014). U.S. local government general obligation debt. Moody's. <https://www.moodys.com/researchdocumentcontentpage.aspx?docid=PBM_1041877>.

Simonsen, B., \& Robbins, M. (2002). Measuring municipal borrowing costs: How missing cost information biases interest rate calculations. Public Budgeting \& Finance, 22(1), 46-59.

Stock, J. H., \& Watson, M. W. (1989). New indexes of coincident and leading economic indicators. In O. J. Blanchard, \& S. Fischer, NBER Macroeconomics Annual (Vol. 4, pp. 351-409). Cambridge, Massachusetts: MIT Press.

Streib, G., Svara, J. H., Waugh, Jr., W. L., \& Klase, K. A. (2007). Conducting research on counties in the 21st century: A new agenda and database considerations. Public Administrative Review, 67(6), 968-983. 
Taylor, S. J. (2005). An introduction to volatility. In S. J. Taylor, Asset Price Dynamics, Volatility, and Prediction (pp. 189-196). Princeton, New Jersey: Princeton University Press.

Trussel, J., \& Patrick, P. (2013). The symptoms and consequences of fiscal distress in municipalities: An investigation of reductions in public services. Accounting and the Public Interest, 13(1), 151-171.

Wallace, W. A. (1981). The association between municipal market measures and selected financial reporting practices. Journal of Accounting Research, 19(2), 207-224.

Wilson, E. (1993). Fiscal performance and municipal borrowing costs. Public Budgeting \& Finance, 3(4), 28-41.

Wilson, E., \& Howard, T. (1984). The association between municipal market measures and selected financial reporting practices: Additional evidence. Journal of Accounting Research, 22(1), 207-224.

Wu, J. C., \& Xia, F. D. (2016). Measuring the macroeconomic impact of monetary policy at the zero lower bound. Journal of Money, Credit and Banking, 48(2-3), 253-391.

Yan, W. (2012). The impact of revenue diversification and economic base on state revenue stability. Journal of Public Budgeting \& Financial Management, 24(1), 58-81.

Zimmerman, J. L. (1977). The municipal accounting maze: An analysis of political incentives. Journal of Accounting Research, 15(1), 107-144. 


\section{Appendix A - Tables}

Table 1

Summary of primary literature.

\begin{tabular}{|c|c|c|c|c|}
\hline Topic & $\begin{array}{l}\text { Author(s) } \\
\text { Year }\end{array}$ & Purpose & Sample & Key Findings \\
\hline $\begin{array}{l}\text { Spending } \\
\text { rate }\end{array}$ & $\begin{array}{l}\text { Wallace } \\
\text { (1981) }\end{array}$ & $\begin{array}{l}\text { Examine effects of auditing } \\
\& \text { accounting variables on } \\
\text { bond ratings and borrowing } \\
\text { cost, as measured by NIC }\end{array}$ & $\begin{array}{l}\mathrm{n}=106 \text { new GO \& } \\
\text { revenue utility bond } \\
\text { issues in 1974-1976 } \\
\text { for FL counties, } \\
\text { cities, schools }\end{array}$ & $\begin{array}{l}\text { - Significant associations between general fund } \\
\text { performance variables with NIC, but not with } \\
\text { bond ratings. } \\
\text { - Negative coefficient between SR deficit and } \\
\text { NIC suggests that SR deficit reduces } \\
\text { borrowing cost. Wallace considers this } \\
\text { finding counterintuitive and attributes this to } \\
\text { the fund accounting process (i.e., modified } \\
\text { accrual basis calls for earlier recognition of } \\
\text { expenditures; thus, deficit condition may } \\
\text { provide a positive signal that municipal } \\
\text { managers have not distorted reporting). }\end{array}$ \\
\hline $\begin{array}{l}\text { Spending } \\
\text { rate }\end{array}$ & $\begin{array}{l}\text { Ingram \& } \\
\text { Copeland } \\
(1982)\end{array}$ & $\begin{array}{l}\text { Part II of an extension of } \\
\text { Wallace (1981) that } \\
\text { examines how degree of } \\
\text { rigor in accounting and } \\
\text { auditing policies are } \\
\text { associated to systematic risk } \\
\text { and alternative measures of } \\
\text { bond yield premiums }\end{array}$ & $\begin{array}{l}\mathrm{n}=122 \\
\text { municipalities that } \\
\text { issued non-callable } \\
\text { GO bonds in } \\
\text { secondary market in } \\
1977\end{array}$ & $\begin{array}{l}\text { - Results are consistent with Wallace (1981) } \\
\text { with negative coefficient for changes in SR on } \\
\text { dependent variable of systematic risk (beta). } \\
\text { - Changes in SR calculated as the percentage } \\
\text { change in total revenue less total expenditure } \\
\text { (defined in Part I by Copeland \& Ingram, } \\
\text { 1982); changes in SR not a volatility measure. } \\
\text { - Degree of rigor in both accounting and } \\
\text { auditing regulations from the state level are } \\
\text { significant to beta and bond yield premiums. }\end{array}$ \\
\hline
\end{tabular}




\begin{tabular}{|c|c|c|c|c|}
\hline Topic & $\begin{array}{l}\text { Author(s) } \\
\text { Year }\end{array}$ & Purpose & Sample & Key Findings \\
\hline $\begin{array}{l}\text { Spending } \\
\text { rate }\end{array}$ & $\begin{array}{l}\text { Wilson \& } \\
\text { Howard } \\
(1984)\end{array}$ & $\begin{array}{l}\text { Replicate and extend on } \\
\text { Wallace (1981) with } \\
\text { methodological } \\
\text { improvements and a larger } \\
\text { sample of bond issues from } \\
\text { municipalities across the } \\
\text { nation }\end{array}$ & $\begin{array}{l}\mathrm{n}=230 \text { GO bonds } \\
\text { issued in 1978- } \\
1981\end{array}$ & $\begin{array}{l}\text { - General fund performance variables are } \\
\text { significantly associated with bond ratings; } \\
\text { (Wallace (1981) only found significance with } \\
\text { NIC). } \\
\text { - Higher current surplus in the general fund is } \\
\text { associated with lower NIC while general fund } \\
\text { deficit is associated with higher NIC. All } \\
\text { results suggest a negative association between } \\
\text { general fund performance and borrowing cost. }\end{array}$ \\
\hline $\begin{array}{l}\text { Spending } \\
\text { rate }\end{array}$ & $\begin{array}{l}\text { Apostolou et al. } \\
\text { (1985) }\end{array}$ & $\begin{array}{l}\text { Examine the possibility that } \\
\text { the association between SR } \\
\text { and NIC changes slope at a } \\
\text { balanced budget point }\end{array}$ & $\begin{array}{l}\mathrm{n}=478 \mathrm{GO} \text { bonds } \\
\text { issued by MN } \\
\text { municipalities in } \\
1977-1980\end{array}$ & $\begin{array}{l}\text { - The rate of surplus spending and rate of deficit } \\
\text { spending are both positively associated to NIC; } \\
\text { supports the change in slope. } \\
\text { - Results provide initial evidence that relation } \\
\text { between SR and NIC is non-monotonic, at a } \\
\text { balanced-budget point. }\end{array}$ \\
\hline $\begin{array}{l}\text { Spending } \\
\text { rate }\end{array}$ & $\begin{array}{l}\text { Plummer et al. } \\
\text { (2007) }\end{array}$ & $\begin{array}{l}\text { Examine whether accruals- } \\
\text { based measures from } \\
\text { GASB's } 34 \text { financial } \\
\text { reporting model provide } \\
\text { incremental information, } \\
\text { relative to modified- } \\
\text { accruals based measures, for } \\
\text { assessment of default risk, } \\
\text { as proxied by debt ratings }\end{array}$ & $\begin{array}{l}\mathrm{n}=530 \text { TX school } \\
\text { districts that issued } \\
\text { information and } \\
\text { GO bonds in } 2002\end{array}$ & $\begin{array}{l}\text { - The accruals-based “earnings” (revenues less } \\
\text { expenditures) does not provide more } \\
\text { incremental information on credit ratings than } \\
\text { the modified-accruals based “earnings” (i.e., } \\
\text { SR of the general fund) } \\
\text { - Best information content to explain debt } \\
\text { ratings is SR and total net assets (an accruals } \\
\text { measure of total assets less total liabilities) } \\
\text { - SR surplus is positively correlated with debt } \\
\text { ratings, suggesting that credit ratings worsen as } \\
\text { surpluses increase. }\end{array}$ \\
\hline
\end{tabular}




\begin{tabular}{|c|c|c|c|c|}
\hline Topic & $\begin{array}{l}\text { Author(s) } \\
\text { Year }\end{array}$ & Purpose & Sample & Key Findings \\
\hline $\begin{array}{l}\text { Spending } \\
\text { rate }\end{array}$ & $\begin{array}{l}\text { Apostolou et al. } \\
\text { (2014) }\end{array}$ & $\begin{array}{l}\text { Examine and validate mixed } \\
\text { findings from prior studies } \\
\text { on SR given the dramatic } \\
\text { growth in municipal market } \\
\text { and stronger SEC oversight }\end{array}$ & $\begin{array}{l}\mathrm{n}=3,285 \mathrm{GO} \\
\text { bonds issued by } \\
314 \mathrm{U} . \mathrm{S} \text {. counties } \\
\text { in } 1995-2007\end{array}$ & $\begin{array}{l}\text { - Association between SR magnitude and TIC } \\
\text { follows a nonlinear, nonmonotonic, and } \\
\text { asymmetric profile, around an equilibrium } \\
\text { point where revenues equals expenditures } \\
\text { (i.e., SR equilibrium). } \\
\text { - Asymmetry suggests that negative SR } \\
\text { (deficit) is more heavily penalized than } \\
\text { positive SR (surplus). } \\
\text { - Maintaining SR at or near SR equilibrium } \\
\text { proxies for managerial competence to keep } \\
\text { borrowing cost at a minimum. }\end{array}$ \\
\hline $\begin{array}{l}\text { Spending } \\
\text { rate }\end{array}$ & $\begin{array}{l}\text { Reck \& Wilson } \\
\text { (2014) }\end{array}$ & $\begin{array}{l}\text { Extend on Plummer et al. } \\
\text { (2007) with a shorter- vs. } \\
\text { longer- term focus for } \\
\text { accruals vs. modified } \\
\text { accruals based measures } \\
\text { from GASB's } 34 \text { financial } \\
\text { reporting model. }\end{array}$ & $\begin{array}{l}\mathrm{n}=185 \text { GO bonds } \\
\text { issued by } \\
\text { municipalities from } \\
2002-2006\end{array}$ & $\begin{array}{l}\text { - Government-wide longer-term accruals are } \\
\text { incrementally useful in estimating TIC when } \\
\text { combined with modified accruals measures. } \\
\text { - General fund performance variables } \\
\text { (measured as revenues less expenditures } \\
\text { scaled by revenues) are negatively associated } \\
\text { with TIC, suggesting that higher borrowing } \\
\text { cost are associated as general fund } \\
\text { performance declines. }\end{array}$ \\
\hline $\begin{array}{l}\text { Corporate } \\
\text { earnings }\end{array}$ & $\begin{array}{l}\text { Plummer \& Tse } \\
\text { (1999) }\end{array}$ & $\begin{array}{l}\text { Examine the conditions that } \\
\text { influence the importance of } \\
\text { earnings to shareholders vs. } \\
\text { bondholders; predictions } \\
\text { based on the liquidation } \\
\text { option hypothesis }\end{array}$ & $\begin{array}{l}\mathrm{n}=1,719 \text { stocks, } \\
\text { and } \mathrm{n}=4,983 \\
\text { corporate bonds } \\
\text { issued in 1986- } \\
1993\end{array}$ & $\begin{array}{l}\text { - Earnings losses are more informative for bond } \\
\text { holders than for shareholders as a company’s } \\
\text { financial condition deteriorates, except for the } \\
\text { most financially sound firms (i.e., } \\
\text { bondholders are more sensitive to downside } \\
\text { risk) } \\
\text { - Controlling for firm financial strength is } \\
\text { important }\end{array}$ \\
\hline
\end{tabular}




\begin{tabular}{|c|c|c|c|c|}
\hline Topic & $\begin{array}{l}\text { Author(s) } \\
\text { Year }\end{array}$ & Purpose & Sample & Key Findings \\
\hline $\begin{array}{l}\text { Corporate } \\
\text { earnings }\end{array}$ & $\begin{array}{l}\text { Bharath et al. } \\
\text { (2008) }\end{array}$ & $\begin{array}{l}\text { Examine how accounting } \\
\text { quality of the firm } \\
\text { influences the firm's } \\
\text { propensity to borrow from } \\
\text { the bank or the bond market } \\
\text { and how these decisions } \\
\text { influence the cost of debt }\end{array}$ & $\begin{array}{l}n=3,681 \text { corporate } \\
\text { bonds, } 12,676 \text { bank } \\
\text { loans issued by the } \\
\text { same firms in } 1988- \\
2003\end{array}$ & $\begin{array}{l}\text { - Accounting quality, proxied by abnormal } \\
\text { operating accruals, is significant to the source } \\
\text { of financing and the cost of debt. } \\
\text { - Firms with relatively lower accounting quality } \\
\text { have higher propensity to pursue bank loans } \\
\text { while firms with relatively higher accounting } \\
\text { quality have higher propensity to pursue } \\
\text { corporate bonds; cost of debt for corporate } \\
\text { bonds is significantly lower. }\end{array}$ \\
\hline $\begin{array}{l}\text { Corporate } \\
\text { earnings }\end{array}$ & $\begin{array}{l}\text { Jiang } \\
(2008)\end{array}$ & $\begin{array}{l}\text { Examine whether earnings } \\
\text { benchmarks reduce a firm's } \\
\text { cost of debt; predictions } \\
\text { based on prospect theory }\end{array}$ & $\begin{array}{l}\mathrm{n}=8,878 \text { debt } \\
\text { ratings issued in } \\
1985-2002 \text {, and } \\
\mathrm{n}=1,798 \text { yield- } \\
\text { spreads from } \\
\text { corporate bonds } \\
\text { issued in 1983- } \\
2002\end{array}$ & $\begin{array}{l}\text { - Among the three benchmarks (beat last year's } \\
\text { earnings, beat analysts forecast, beat zero } \\
\text { earnings), the zero-earnings benchmark is } \\
\text { most salient for cost of debt. }\end{array}$ \\
\hline $\begin{array}{l}\text { Corporate } \\
\text { earnings }\end{array}$ & $\begin{array}{l}\text { Easton et al. } \\
\text { (2009) }\end{array}$ & $\begin{array}{l}\text { Examine the role of } \\
\text { earnings in corporate bond } \\
\text { market }\end{array}$ & $\begin{array}{l}\mathrm{n}=10,237 \text { bonds } \\
\text { issued in 1994- } \\
2006\end{array}$ & $\begin{array}{l}\text { - Nonlinear payoff structure of bond securities } \\
\text { affects the role of accounting earnings such } \\
\text { that unexpected earnings, annual bond } \\
\text { returns, and trade volume are greater for bad } \\
\text { earnings news (i.e., losses). }\end{array}$ \\
\hline $\begin{array}{l}\text { Corporate } \\
\text { earnings }\end{array}$ & $\begin{array}{l}\text { Defond \& Zhang } \\
\text { (2014) }\end{array}$ & $\begin{array}{l}\text { Test predictions regarding } \\
\text { the timing of stock market } \\
\text { vs. bond market reactions to } \\
\text { good vs bad news on } \\
\text { earnings }\end{array}$ & $\begin{array}{l}\mathrm{n}=11,641 \\
\text { quarterly earnings } \\
\text { announcements and } \\
\mathrm{n}=47,522 \text { bond- } \\
\text { year observations } \\
1996-2006\end{array}$ & $\begin{array}{l}\text { - Bond price quotes impound most bad } \\
\text { earnings news information in the pre- } \\
\text { announcement period; suggest an overreaction } \\
\text { by bond investors to bad earnings news. } \\
\text { - Speculative grade bonds react more strongly } \\
\text { to bad earnings news, relative to investment } \\
\text { grade bonds. }\end{array}$ \\
\hline
\end{tabular}




\begin{tabular}{|c|c|c|c|c|}
\hline Topic & $\begin{array}{l}\text { Author(s) } \\
\text { Year }\end{array}$ & Purpose & Sample & Key Findings \\
\hline $\begin{array}{l}\text { Corporate } \\
\text { earnings }\end{array}$ & $\begin{array}{l}\text { Givoly et al. } \\
\text { (2017) }\end{array}$ & $\begin{array}{l}\text { Examine whether the } \\
\text { relevance of accounting } \\
\text { information has increased or } \\
\text { decreased over time in the } \\
\text { corporate debt market }\end{array}$ & $\begin{array}{l}n=13,910 \text { bond } \\
\text { series issued by } \\
2,754 \text { firms from } \\
1975-2013\end{array}$ & $\begin{array}{l}\text { - Information content in the corporate bond } \\
\text { market has steadily increased, relative to the } \\
\text { information content in the equity market. } \\
\text { - Significant association of information content } \\
\text { to economic and reporting variables; suggests } \\
\text { that when GDP coefficient is negative, } \\
\text { accounting information has more content (i.e., } \\
\text { more relevance). }\end{array}$ \\
\hline $\begin{array}{l}\text { Earnings } \\
\text { volatility }\end{array}$ & $\begin{array}{l}\text { Graham et al. } \\
\text { (2005) }\end{array}$ & $\begin{array}{l}\text { Examine factors that affect } \\
\text { earnings and disclosure } \\
\text { decisions among CFOs }\end{array}$ & $\begin{array}{l}\mathrm{n}=401 \text { CFOs of } \\
\text { public and private } \\
\text { companies in } 2003 \\
(10.4 \% \text { response } \\
\text { rate for survey) and } \\
\text { interviews of subset } \\
\text { of } \mathrm{n}=20 \text { CFOs }\end{array}$ & $\begin{array}{l}\text { - CFOs prefer to avoid volatility and to provide } \\
\text { smoothness in earnings information. } \\
\text { - Interviews disclose importance of beating } \\
\text { earnings. } \\
\text { - Some survey evidence supports the notion } \\
\text { that earnings-loss avoidance can lower cost of } \\
\text { debt (found only among highly leveraged, } \\
\text { unprofitable, and/or private firms) }\end{array}$ \\
\hline $\begin{array}{l}\text { Earnings } \\
\text { volatility }\end{array}$ & $\begin{array}{l}\text { Dichev \& Tang } \\
\text { (2008) }\end{array}$ & $\begin{array}{l}\text { Present and test a theory on } \\
\text { the correlation between } \\
\text { contemporaneous revenues } \\
\text { and expenses based on the } \\
\text { degree of matching }\end{array}$ & $\begin{array}{l}\mathrm{n}=1,000 \text { large } \\
\mathrm{U} . \mathrm{S} \text {. firms from } \\
1967-2003\end{array}$ & $\begin{array}{l}\text { - Given the assumption that revenues and } \\
\text { expenses are perfectly matched, the volatility } \\
\text { of earnings is positively associated with the } \\
\text { volatility of economic shocks and the } \\
\text { persistence of economic shocks. } \\
\text { - Trend of matching has worsened over the } \\
\text { sample period; authors suggest that continued } \\
\text { emphasis of accounting standard setters } \\
\text { towards fair value accounting will most likely } \\
\text { continue to result in greater mismatch } \\
\text { between revenues and expenses. }\end{array}$ \\
\hline
\end{tabular}




\begin{tabular}{|c|c|c|c|c|}
\hline Topic & $\begin{array}{l}\text { Author(s) } \\
\text { Year }\end{array}$ & Purpose & Sample & Key Findings \\
\hline $\begin{array}{l}\text { Earnings } \\
\text { volatility }\end{array}$ & $\begin{array}{l}\text { Dichev \& Tang } \\
\text { (2009) }\end{array}$ & $\begin{array}{l}\text { Examine the association } \\
\text { between earnings volatility } \\
\text { and earnings persistence }\end{array}$ & $\begin{array}{l}n=22,113 \text { firm- } \\
\text { years observations } \\
\text { from 12/31 from } \\
\text { 1984-2004 }\end{array}$ & $\begin{array}{l}\text { - Earnings volatility reduces earnings } \\
\text { persistence; decreased persistence reduces } \\
\text { predictability of earnings. } \\
\text { - Inclusion of earnings volatility is significant } \\
\text { to improving predications of short- and long- } \\
\text { term earnings (out to } 5 \text { years). }\end{array}$ \\
\hline $\begin{array}{l}\text { Earnings } \\
\text { volatility }\end{array}$ & $\begin{array}{l}\text { Gore } \\
\text { (2009) }\end{array}$ & $\begin{array}{l}\text { Examine the determinants } \\
\text { of cash levels in municipal } \\
\text { government }\end{array}$ & $\begin{array}{l}\mathrm{n}=9,413 \\
\text { municipalities } \\
\text { financial data } \\
\text { reported to the U. } \\
\text { S. Census Bureau } \\
\text { for } 1997-2002\end{array}$ & $\begin{array}{l}\text { - Revenue volatility (a determinant of SR) is } \\
\text { significant to excess cash levels among } \\
\text { municipalities; further, these excess cash } \\
\text { levels are associated with evidence consistent } \\
\text { with agency problems between municipal } \\
\text { managers and citizens (e.g., greater } \\
\text { managerial bonuses, administrative spending) }\end{array}$ \\
\hline $\begin{array}{l}\text { Earnings } \\
\text { volatility }\end{array}$ & $\begin{array}{l}\text { Felix } \\
(2015)\end{array}$ & $\begin{array}{l}\text { Examine the use of inter- } \\
\text { fund transfers by } \\
\text { municipalities to manage } \\
\text { the general fund at or near } \\
\text { zero }\end{array}$ & $\begin{array}{l}\mathrm{n}=103 \\
\text { municipalities with } \\
\text { populations } \\
>25,000 \text { for } \\
2001-2003 \text { that }\end{array}$ & $\begin{array}{l}\text { - Evidence supports prediction that inter-fund } \\
\text { transfers are used by municipalities to } \\
\text { maintain the general fund at or near zero; } \\
\text { evidence of this practice is most pronounced } \\
\text { for municipalities that have greater external } \\
\text { oversight; results are consistent with CFO } \\
\text { preference for smoothness in earnings } \\
\text { (Graham et al., 2005) }\end{array}$ \\
\hline $\begin{array}{l}\text { Earnings } \\
\text { volatility }\end{array}$ & $\begin{array}{l}\text { Erickson et al. } \\
\text { (2017) }\end{array}$ & $\begin{array}{l}\text { Examine investor's risk } \\
\text { judgements to earnings } \\
\text { volatility (volatile/smooth) } \\
\text { and operating cash flow } \\
\text { volatility (volatile/smooth) }\end{array}$ & $\begin{array}{l}\mathrm{n}=121 \text { business } \\
\text { school alumni from } \\
\text { a large U. } \mathrm{S} \text {. } \\
\text { university; } 6.7 \% \\
\text { response rate for a } \\
2 \times 2 \text { between- } \\
\text { subjects design }\end{array}$ & $\begin{array}{l}\text { - Investors perceive risk when both operating } \\
\text { cash flows and earnings are volatile }\end{array}$ \\
\hline
\end{tabular}




\begin{tabular}{|c|c|c|c|c|}
\hline Topic & $\begin{array}{l}\text { Author(s) } \\
\text { Year }\end{array}$ & Purpose & Sample & Key Findings \\
\hline $\begin{array}{l}\text { Financial } \\
\text { crisis }\end{array}$ & $\begin{array}{l}\text { Kothari \& Lester } \\
\text { (2012) }\end{array}$ & $\begin{array}{l}\text { Discuss the role of GAAP } \\
\text { accounting surrounding the } \\
\text { financial crisis of late } 2007 \\
\text { and offer lessons learned }\end{array}$ & $\mathrm{n} / \mathrm{a}$ & $\begin{array}{l}\text { - Fair value accounting was a major } \\
\text { contributing factor to the onset of the } \\
\text { financial crisis in late December } 2007 \text {. } \\
\text { - Loans repackaged by banks from inflated } \\
\text { asset valuations, coupled by a prevalence of } \\
\text { variable mortgages sold in the subprime } \\
\text { mortgage market led to a drastic decline in the } \\
\text { financial sector when the Federal Reserve } \\
\text { raised interest rates in } 2005 \text {. }\end{array}$ \\
\hline $\begin{array}{l}\text { Financial } \\
\text { crisis }\end{array}$ & $\begin{array}{l}\text { Gross et al. } \\
\text { (2012) }\end{array}$ & $\begin{array}{l}\text { Examine trends in two } \\
\text { major sources of revenue } \\
\text { (property taxes and state } \\
\text { aid), in the period following } \\
\text { the Great Recession of } 2008\end{array}$ & $\begin{array}{l}\mathrm{n}=30 \text { cities from } \\
\text { the largest } \\
\text { metropolitan areas } \\
\text { in the U. S., from } \\
2009 \text { to } 2011 \text {; data } \\
\text { analyzed is from } \\
\text { surveys used in } \\
\text { other studies }\end{array}$ & $\begin{array}{l}\text { - Municipal revenues sources were profoundly } \\
\text { affected; both state aid and property taxes } \\
\text { declined such that it hindered local } \\
\text { borrowing. } \\
\text { - The process of tax assessments prolonged the } \\
\text { effects of the financial crisis into the recovery } \\
\text { period. }\end{array}$ \\
\hline $\begin{array}{l}\text { Financial } \\
\text { crisis }\end{array}$ & $\begin{array}{l}\text { Atwell et al. } \\
\text { (2013) }\end{array}$ & $\begin{array}{l}\text { Examine the range of state } \\
\text { intervention for } \\
\text { municipalities in fiscal } \\
\text { distress }\end{array}$ & $\begin{array}{l}\mathrm{n}=50 \text { U. S. states } \\
\text { and a subsample of } \\
\mathrm{n}=7 \text { states for } \\
\text { comparative } \\
\text { analyses }\end{array}$ & $\begin{array}{l}\text { - Stages of municipal difficulty are defined, } \\
\text { based on practice: distress, crisis, bankruptcy. } \\
\text { - A major incentive for state-level monitoring } \\
\text { and intervention of municipalities is to avoid } \\
\text { downgrades in state credit ratings. }\end{array}$ \\
\hline $\begin{array}{l}\text { Financial } \\
\text { crisis }\end{array}$ & $\begin{array}{l}\text { Park et al. } \\
\text { (2017) }\end{array}$ & $\begin{array}{l}\text { Examine the association } \\
\text { between internal control } \\
\text { deficiencies and municipal } \\
\text { borrowing cost }\end{array}$ & $\begin{array}{l}\mathrm{n}=3,633 \text { municipal } \\
\text { bonds issued by } \\
\text { CA, TX, WA in } \\
\text { 2005-2012 }\end{array}$ & $\begin{array}{l}\text { - Internal control deficiencies from material } \\
\text { weaknesses are significantly associated with } \\
\text { municipal bond borrowing cost. } \\
\text { - No significant difference in TIC is evident for } \\
\text { the financial crisis period. }\end{array}$ \\
\hline
\end{tabular}


Table 2

Variable descriptions.

\begin{tabular}{|c|c|c|}
\hline Variable & Name & Definition \\
\hline True interest cost & TIC & $\begin{array}{l}\text { interest expense incurred by county (i) issuer } \\
\text { of municipal bonds; reported as a percentage }\end{array}$ \\
\hline Spending rate & SR & $\begin{array}{l}\text { total revenues minus total expenditures } \\
\text { scaled by population }\end{array}$ \\
\hline Spending rate magnitude & SR1 & absolute value of SR \\
\hline Spending rate magnitude (surplus) & SRS & $\begin{array}{l}\text { equal to the absolute value of } \mathrm{SR} \text { if } \mathrm{SR} \text { is in a } \\
\text { surplus condition (i.e., } \mathrm{SR}>0 \text { ) }\end{array}$ \\
\hline Spending rate magnitude (deficit) & SRD & $\begin{array}{l}\text { equal to the absolute value of SR if SR is in a } \\
\text { deficit condition (i.e., } \mathrm{SR}<0 \text { ) }\end{array}$ \\
\hline Spending rate volatility & SRVOL & $\begin{array}{l}\text { coefficient of variation of SR over the } \\
\text { previous five years }\end{array}$ \\
\hline State leading index & ECON & $\begin{array}{l}\text { the leading index for the State }(j) \text { of county(i) } \\
\text { for the same month in which the bond was } \\
\text { issued }\end{array}$ \\
\hline Unassigned fund balance & FB & unassigned fund balance scaled by population \\
\hline Yield curve slope & SLOPE & average maturity of the bond issue in years \\
\hline Yield curve curvature & CURVE & $\begin{array}{l}\text { the inverse of the average maturity of the } \\
\text { bond issue in years (i.e., 1/SLOPE) }\end{array}$ \\
\hline Yield curve level & LEVEL & $\begin{array}{l}\text { the combination of the effective federal funds } \\
\text { rate (1995-2008) and the shadow federal } \\
\text { funds rate (2009-2014), for the same month } \\
\text { in which the bond was issued }\end{array}$ \\
\hline Bond issue amount & $\mathrm{AMT}$ & $\begin{array}{l}\text { natural log of the average maturity of the } \\
\text { bond issue scaled by population }\end{array}$ \\
\hline Pricing mechanism & BID & $\begin{array}{l}\text { a binary variable assigned the value of } 1 \text { if } \\
\text { issue was competitively bid; } 0 \text { if negotiated }\end{array}$ \\
\hline Bond rating & $\mathrm{BR}$ & $\begin{array}{l}\text { a binary variable assigned the value of } 1 \text { if the } \\
\text { issue carries the 'Aaa' Moody's rating; else } 0\end{array}$ \\
\hline Call feature & CALL & $\begin{array}{l}\text { a binary variable assigned the value of } 1 \text { if the } \\
\text { bond issue is callable; else } 0\end{array}$ \\
\hline
\end{tabular}




\section{Table 3}

Summary of expectations for tests.

\begin{tabular}{|c|c|c|}
\hline Hypotheses & Variables tested & Expectations \\
\hline $\begin{array}{l}\text { H1: The association between spending } \\
\text { rate magnitude and borrowing cost is } \\
\text { moderated by economic activity. }\end{array}$ & SR1×ECON & $\beta$ is statistically significant \\
\hline $\begin{array}{l}\text { H2: Negative departures from SR equilibrium } \\
\text { (SR deficits) are assessed more severely } \\
\text { on TIC as economic activity declines. }\end{array}$ & SRD $\times E C O N$ & $\beta>0$ \\
\hline $\begin{array}{l}\text { H3: Positive departures from SR equilibrium } \\
\text { (SR surpluses) are assessed less severely } \\
\text { on TIC as economic activity declines. }\end{array}$ & $\mathrm{SRS} \times \mathrm{ECON}$ & $\beta<0$ \\
\hline RQ1: Is TIC associated with SR volatility? & SRVOL & $\beta$ is statistically significant \\
\hline $\begin{array}{l}\text { RQ2: Is the association between TIC and SR } \\
\text { volatility moderated by economic } \\
\text { activity? }\end{array}$ & SRVOL $\times E C O N$ & $\beta$ is statistically significant \\
\hline
\end{tabular}




\section{Table 4}

Summary of sample selection.

\begin{tabular}{ll}
\hline Steps in data preparation & Sample size \\
\hline New GO bond issued by primary county governments (1995-2014) & 17,001 \\
Less observations without values for TIC & $(12,638)$ \\
Less duplicates, missing values, incorrect entries for cities & $(15)$ \\
Less observations after merge with reported accounting data & $(2,377)$ \\
Less removal of an unverifiable outlier for TIC & $(1)$ \\
\hline Total & $\mathrm{n}=$ \\
\hline Data are from four sources: Thomson Reuter's SDC Platinum for GO bonds, GFOA's financial \\
$\begin{array}{l}\text { indicators database for CAFR data, the Federal Reserve Bank of Philadelphia’s database for state } \\
\text { leading indexes, and the Federal Reserve Bank of Atlanta for federal funds rate data. }\end{array}$
\end{tabular}


Table 5

Sample distribution by state.

\begin{tabular}{|c|c|c|c|c|}
\hline State & $\begin{array}{l}\text { State } \\
\text { Abbr. }\end{array}$ & $\begin{array}{l}\text { Number of } \\
\text { county issuers }\end{array}$ & $\begin{array}{l}\text { Number of new } \\
\text { GO bond issues }\end{array}$ & $\begin{array}{l}\text { Percentage of } \\
\text { the sample (\%) }\end{array}$ \\
\hline Maryland & $\mathrm{MD}$ & 14 & 224 & 11.37 \\
\hline Wisconsin & WI & 15 & 195 & 9.90 \\
\hline North Carolina & NC & 44 & 178 & 9.04 \\
\hline Michigan & MI & 22 & 155 & 7.87 \\
\hline Minnesota & $\mathrm{MN}$ & 13 & 128 & 6.50 \\
\hline Texas & TX & 26 & 111 & 5.63 \\
\hline South Carolina & SC & 17 & 106 & 5.38 \\
\hline Virginia & VA & 13 & 105 & 5.33 \\
\hline Washington & WA & 9 & 99 & 5.03 \\
\hline Tennessee & $\mathrm{TN}$ & 7 & 85 & 4.31 \\
\hline Nevada & NV & 2 & 78 & 3.96 \\
\hline New York & NY & 6 & 77 & 3.91 \\
\hline Florida & FL & 16 & 55 & 2.79 \\
\hline Iowa & IA & 5 & 53 & 2.69 \\
\hline Kansas & KS & 3 & 49 & 2.49 \\
\hline California & CA & 17 & 46 & 2.34 \\
\hline Illinois & IL & 7 & 41 & 2.08 \\
\hline Ohio & $\mathrm{OH}$ & 11 & 41 & 2.08 \\
\hline Oregon & OR & 9 & 36 & 1.83 \\
\hline Utah & UT & 3 & 19 & 0.96 \\
\hline Georgia & GA & 5 & 16 & 0.81 \\
\hline Pennsylvania & $\mathrm{PA}$ & 5 & 13 & 0.66 \\
\hline Louisiana & LA & 4 & 11 & 0.56 \\
\hline Colorado & $\mathrm{CO}$ & 3 & 6 & 0.30 \\
\hline Missouri & MO & 2 & 6 & 0.30 \\
\hline Kentucky & $\mathrm{KY}$ & 1 & 5 & 0.25 \\
\hline Montana & MT & 2 & 5 & 0.25 \\
\hline New Mexico & NM & 2 & 5 & 0.25 \\
\hline Delaware & $\mathrm{DE}$ & 2 & 4 & 0.20 \\
\hline Hawaii & HI & 2 & 4 & 0.20 \\
\hline Arizona & $\mathrm{AZ}$ & 2 & 3 & 0.15 \\
\hline Idaho & ID & 1 & 3 & 0.15 \\
\hline Maine & $\mathrm{ME}$ & 1 & 3 & 0.15 \\
\hline Oklahoma & $\mathrm{OK}$ & 1 & 3 & 0.15 \\
\hline Indiana & IN & 1 & 1 & 0.05 \\
\hline North Dakota & ND & 1 & 1 & 0.05 \\
\hline Totals & 36 & 294 & 1,970 & $100.00 \%$ \\
\hline
\end{tabular}

This table is sorted by the number of GO bond issues (in descending order). 
Table 6

Sample distribution by year.

\begin{tabular}{lll}
\hline Year & $\begin{array}{l}\text { Number of new } \\
\text { GO bond issues }\end{array}$ & $\begin{array}{l}\text { Percentage of the } \\
\text { sample (\%) }\end{array}$ \\
\hline 1995 & 34 & 1.73 \\
1996 & 73 & 3.71 \\
1997 & 61 & 3.10 \\
1998 & 86 & 4.37 \\
1999 & 63 & 3.20 \\
2000 & 66 & 3.35 \\
2001 & 98 & 4.97 \\
2002 & 95 & 4.82 \\
2003 & 107 & 5.43 \\
2004 & 117 & 5.94 \\
2005 & 107 & 5.43 \\
2006 & 105 & 5.33 \\
2007 & 102 & 5.18 \\
2008 & 99 & 5.03 \\
2009 & 156 & 7.92 \\
2010 & 169 & 8.58 \\
2011 & 103 & 5.23 \\
2012 & 118 & 5.99 \\
2013 & 116 & 5.89 \\
2014 & 95 & 4.82 \\
\hline Totals & 1,970 & $100.00 \%$ \\
\hline Representing GO bond issues from 294 counties among \\
36 states. & & \\
\hline
\end{tabular}




\section{Table 7}

Sample distribution by economic period.

\begin{tabular}{lllll}
\hline Economic period & $\begin{array}{l}\text { Relevant dates } \\
\text { (inclusive) }^{a}\end{array}$ & $\begin{array}{l}\text { Number of new } \\
\text { GO bond issues }\end{array}$ & $\begin{array}{l}\text { Percentage of the } \\
\text { sample (\%) }\end{array}$ & $\begin{array}{l}\text { Size } \\
\text { (amt in \$mil) }\end{array}$ \\
\hline Pre-financial crisis & Jan 1995 - Nov 2007 & 1,098 & 55.74 & 39,598 \\
Financial crisis & Dec 2007 - Jun 2009 & 176 & 8.93 & 7,156 \\
Recovery & Jul 2009 - Jun 2014 & 696 & 35.33 & 26,541 \\
\hline Totals & 1,970 & 100.00 & 73,295 \\
\hline
\end{tabular}

aSource: National Bureau of Economic Research (NBER). 


\section{Table 8}

Descriptive statistics.

\begin{tabular}{|c|c|c|c|c|}
\hline \multicolumn{5}{|l|}{ Panel A: continuous } \\
\hline Variables & Mean & Std. Dev. & Min & Max \\
\hline TIC & 3.640 & 1.220 & 0.120 & 7.160 \\
\hline SR (no magnitude) & 0.087 & 0.204 & -0.425 & 1.394 \\
\hline SR1 & 0.102 & 0.196 & 0.000 & 1.394 \\
\hline SRS & 0.094 & 0.197 & 0.000 & 1.394 \\
\hline SRD & 0.008 & 0.033 & 0.000 & 0.425 \\
\hline SRVOL & 0.237 & 4.455 & -44.331 & 31.340 \\
\hline ECON & 0.978 & 1.515 & -8.204 & 5.233 \\
\hline \multicolumn{5}{|l|}{ Control variables: } \\
\hline FB & 0.086 & 0.085 & -0.177 & 0.793 \\
\hline SLOPE & 15.574 & 7.148 & 0.364 & 99.000 \\
\hline CURVE & 0.120 & 0.222 & 0.010 & 2.747 \\
\hline LEVEL & 1.901 & 2.885 & -2.986 & 7.070 \\
\hline AMT & -9.984 & 1.254 & -16.236 & -6.973 \\
\hline AMT (face value) ${ }^{\mathrm{a}}$ & 37.205 & 61.532 & 0.280 & 850.000 \\
\hline \multicolumn{5}{|l|}{ Panel B: categorical ${ }^{\mathrm{b}}$} \\
\hline Variables & Frequency & \multicolumn{3}{|c|}{ Relative Frequency (\%) } \\
\hline BID & 1,865 & \multicolumn{3}{|c|}{$94.6 \%$} \\
\hline $\mathrm{BR}$ & 1,707 & \multicolumn{3}{|l|}{$86.7 \%$} \\
\hline CALL & 1,449 & \multicolumn{3}{|l|}{$73.6 \%$} \\
\hline
\end{tabular}

${ }^{a}$ Reported in \$millions.

${ }^{\mathrm{b}}$ Compiled for bond characteristics that are coded 1 out of the full sample $(n=1,970)$ :

BID is coded 1 if competitively bid. BR is coded 1 for Moody's 'Aaa' long-term rating. CALL is coded 1 if the bond is callable. 


\section{Table 9}

Pearson ( $r$ ) correlation values.

\begin{tabular}{|c|c|c|c|c|c|c|c|c|c|c|c|c|c|c|c|}
\hline Variables & TIC & $S R$ & SR1 & SRS & $S R D$ & SRVOL & ECON & $F B$ & SLOPE & CURVE & LEVEL & $A M T$ & $B I D$ & $B R 2$ & $C A L L$ \\
\hline TIC & 1.000 & & & & & & & & & & & & & & \\
\hline$S R$ & $0.189 *$ & 1.000 & & & & & & & & & & & & & \\
\hline SR1 & $0.183 *$ & $0.945 *$ & 1.000 & & & & & & & & & & & & \\
\hline SRS & $0.189 *$ & $0.987 *$ & $0.986^{*}$ & 1.000 & & & & & & & & & & & \\
\hline$S R D$ & -0.038 & $-0.270 *$ & $0.060^{*}$ & $-0.110 *$ & 1.000 & & & & & & & & & & \\
\hline SRVOL & $0.068 *$ & 0.010 & 0.011 & 0.010 & 0.002 & 1.000 & & & & & & & & & \\
\hline ECON & $-0.065 *$ & 0.030 & 0.039 & 0.035 & 0.023 & $-0.056^{*}$ & 1.000 & & & & & & & & \\
\hline$F B$ & $-0.175^{*}$ & $0.147 *$ & $0.171^{*}$ & $0.161^{*}$ & $0.056 *$ & 0.024 & -0.025 & 1.000 & & & & & & & \\
\hline SLOPE & 0.515* & $0.164 *$ & $0.169 *$ & $0.169 *$ & -0.003 & 0.051 & -0.029 & 0.029 & 1.000 & & & & & & \\
\hline CURVE & $-0.340 *$ & $-0.089 *$ & $-0.085 *$ & $-0.088 *$ & 0.024 & -0.014 & $0.059 *$ & $-0.058 *$ & $-0.544 *$ & 1.000 & & & & & \\
\hline LEVEL & 0.671* & $0.216^{*}$ & $0.209 *$ & $0.216^{*}$ & $-0.046 *$ & 0.003 & $0.111^{*}$ & $-0.157^{*}$ & 0.099* & -0.006 & 1.000 & & & & \\
\hline$A M T$ & -0.020 & $0.236 *$ & $0.266^{*}$ & $0.254^{*}$ & $0.063^{*}$ & $0.092 *$ & -0.023 & $0.315^{*}$ & $0.197^{*}$ & -0.034 & -0.034 & 1.000 & & & \\
\hline$B I D$ & 0.028 & $0.052 *$ & $0.045^{*}$ & $0.049 *$ & -0.028 & -0.013 & -0.040 & $0.081 *$ & $0.102^{*}$ & $-0.232 *$ & -0.025 & 0.021 & 1.000 & & \\
\hline$B R$ & $0.125^{*}$ & $0.085 *$ & $0.091^{*}$ & $0.089 *$ & 0.010 & 0.006 & 0.000 & $0.083^{*}$ & $0.235^{*}$ & $-0.458 *$ & -0.003 & $0.081^{*}$ & $0.186^{*}$ & 1.000 & \\
\hline CALL & $0.419 *$ & $0.117 *$ & $0.119 *$ & $0.119 *$ & -0.006 & 0.032 & -0.010 & 0.032 & 0.664* & $-0.439 *$ & $0.076 *$ & $0.148^{*}$ & $0.140^{*}$ & $0.188^{*}$ & 1.000 \\
\hline
\end{tabular}

* indicates significance at the $\mathrm{p}<0.050$ level. Values are in bold if they are significant at $\mathrm{p}<0.050$ level and have a Pearson's correlation value $(r)$ that is greater than the absolute value of 0.50 (i.e., $|0.50|$ ). 
Table 10

Regression results for H1 (sample period 1995-2014).

\begin{tabular}{llll}
\hline Dependent variable (TIC) & Variable & $\begin{array}{c}(1) \\
\text { No interaction }\end{array}$ & $\begin{array}{c}(2) \\
\text { Interaction }^{a}\end{array}$ \\
\hline SR magnitude & SR1 & $0.248^{* * *}$ & 0.054 \\
& & $(3.26)$ & $(0.48)$ \\
State leading index & ECON & $-0.052^{* * *}$ & $-0.065^{* * *}$ \\
& & $(-3.79)$ & $(-4.46)$ \\
Interaction of SR magnitude & SR1×ECON & n/a & $0.155^{* * * *}$ \\
and state leading index & & & $(3.05)$ \\
& & & \\
Control variables: & & $-0.905^{* * *}$ & $-0.872^{* * *}$ \\
Unassigned fund balance & FB & $0.054^{* * *}$ & $0.055^{* * *}$ \\
Yield curve attributes & SLOPE & $-0.547^{* *}$ & $-0.544^{* *}$ \\
& CURVE & $0.268^{* * *}$ & $0.267^{* * *}$ \\
Bond characteristics & LEVEL & $-0.051^{* * *}$ & $-0.052^{* * *}$ \\
& AMT & $-0.153^{*}$ & $-0.152^{*}$ \\
& BID & -0.059 & -0.056 \\
& BR & $0.377^{* * *}$ & $0.373^{* * *}$ \\
State-level FE & CALL & included & included \\
& & 1,970 & 1,970 \\
& N (bonds) & 443.479 & 489.690 \\
& F-statistic & 0.0000 \\
& Model p-value & 0.0000 & 0.7183 \\
\hline
\end{tabular}

$*, * *, * * *$ indicate significance at $\mathrm{p}<0.100, \mathrm{p}<0.050, \mathrm{p}<0.010$ levels, respectively (two-tailed).

${ }^{a} \mathrm{t}$-statistics for independent variables are in parentheses using robust standard errors by state.

${ }^{\mathrm{b}}$ Degrees of freedom are $(10,35)$ in column 1 and $(11,35)$ in column 2.

This table reports regression results for $\mathrm{H} 1$, which tested for a significant interaction between spending rate magnitude (SR1) and the state leading index (ECON); no direction is predicted for the interaction. Column 1 shows significance for SR1 at $0.248(p<0.010)$ and (ECON) at $-0.052(p<0.010)$, prior to interaction. Column 2 shows a positive interaction between SR1 and ECON at $0.155(p<0.010)$. 
Table 11

Regression results for H2 and H3 (sample period 1995-2014).

\begin{tabular}{|c|c|c|c|}
\hline Dependent variable (TIC) & Variable & $\begin{array}{c}\text { (1) } \\
\text { No interactions } \\
\text { a }\end{array}$ & $\begin{array}{c}(2) \\
\text { Interactions }\end{array}$ \\
\hline SR magnitude (surplus) & SRS & $\begin{array}{l}0.247 * * * \\
(2.96)\end{array}$ & $\begin{array}{l}0.042 \\
(0.35)\end{array}$ \\
\hline SR magnitude (deficit) & SRD & $\begin{array}{l}0.888 * * * \\
(2.86)\end{array}$ & $\begin{array}{l}-0.537 \\
(-0.63)\end{array}$ \\
\hline State leading index & ECON & $\begin{array}{l}-0.052^{* * *} \\
(-3.80)\end{array}$ & $\begin{array}{l}-0.069 * * * \\
(-4.80)\end{array}$ \\
\hline $\begin{array}{l}\text { Interaction of SR surplus and } \\
\text { state leading index }\end{array}$ & SRS $\times E C O N$ & $\mathrm{n} / \mathrm{a}$ & $\begin{array}{l}0.153^{* * *} \\
(3.11)\end{array}$ \\
\hline $\begin{array}{l}\text { Interaction of SR deficit and } \\
\text { state leading index }\end{array}$ & $\mathrm{SRD} \times \mathrm{ECON}$ & $\mathrm{n} / \mathrm{a}$ & $\begin{array}{l}0.968 * \\
(1.69)\end{array}$ \\
\hline \multicolumn{4}{|l|}{ Control variables: } \\
\hline Unassigned fund balance & $\mathrm{FB}$ & $-0.921 * * *$ & $-0.915 * * *$ \\
\hline \multirow[t]{3}{*}{ Yield curve attributes } & SLOPE & $0.055^{* * *}$ & $0.055 * * *$ \\
\hline & CURVE & $-0.547 * *$ & $-0.541 * *$ \\
\hline & LEVEL & $0.268 * * *$ & $0.267 * * *$ \\
\hline \multirow[t]{4}{*}{ Bond characteristics } & $\mathrm{AMT}$ & $-0.051 * * *$ & $-0.052 * * *$ \\
\hline & BID & $-0.149 *$ & $-0.154 *$ \\
\hline & $\mathrm{BR}$ & -0.059 & -0.058 \\
\hline & CALL & $0.377^{* * *}$ & $0.374 * * *$ \\
\hline \multirow[t]{5}{*}{ State-level FE } & & included & included \\
\hline & N (bonds) & 1,970 & 1,970 \\
\hline & F-statistic ${ }^{b}$ & 622.080 & 1451.041 \\
\hline & Model p-value & 0.0000 & 0.0000 \\
\hline & $\mathrm{R}^{2}$ (within) & 0.7177 & 0.7189 \\
\hline
\end{tabular}

$*, * *, * * *$ indicate significance at $\mathrm{p}<0.100, \mathrm{p}<0.050, \mathrm{p}<0.010$ levels, respectively (two-tailed).

${ }^{a}$ t-statistics for independent variables are in parentheses using robust standard errors by state.

${ }^{\mathrm{b}}$ Degrees of freedom are $(11,35)$ in column 1 and $(13,35)$ in column 2.

This table reports regression results for $\mathrm{H} 2$ and $\mathrm{H} 3$. H2 tested for a significant interaction between the magnitude for spending rate deficit (SRD) and ECON. H3 tested for a significant interaction between the magnitude for spending rate surplus (SRS) and ECON. Column 1 shows significance for SRD at $0.888(p<0.010)$ and SRS at $0.247(p<0.010)$, prior to interaction with the state leading index. Column 1 also shows significance for the state leading index (ECON) at $-0.052(p<0.010)$. In column 2 , a positive interaction between SRS and ECON is estimated at $0.153(p<0.010)$. The interaction between SRD and ECON is estimated at $0.968(p<0.100)$, but does not reach a conventional level of significance. 
Table 12

Adjusted predictions of TIC on SR for select positive and negative ECON values

\begin{tabular}{l|ll|ll}
\hline $\begin{array}{l}\text { Departure from SR equilibrium } \\
\text { (SRS observations only) }\end{array}$ & ECON $>0$ & Predicted TIC & ECON $<0$ & Predicted TIC \\
\hline$\mu=0.094$ & +2.0 & 3.570 & -2.0 & 3.845 \\
$1 \sigma=0.291$ & & 3.578 & & 3.853 \\
$2 \sigma=0.488$ & & 3.586 & & 3.862 \\
$3 \sigma=0.685$ & & 3.595 & 3.870 \\
\hline$\mu=0.094$ & +1.5 & 3.605 & -1.5 & 3.811 \\
$1 \sigma=0.291$ & & 3.613 & & 3.819 \\
$2 \sigma=0.488$ & & 3.621 & 3.827 \\
$3 \sigma=0.685$ & & 3.629 & & 3.835 \\
\hline$\mu=0.094$ & +1.0 & 3.639 & & 3.775 \\
$1 \sigma=0.291$ & & 3.647 & & 3.785 \\
$2 \sigma=0.488$ & & 3.655 & 3.793 \\
$3 \sigma=0.685$ & +0.5 & 3.664 & -0.5 & 3.801 \\
\hline$\mu=0.094$ & & 3.681 & & 3.742 \\
$1 \sigma=0.291$ & & 3.690 & & 3.750 \\
$2 \sigma=0.488$ & & 3.698 & & 3.767 \\
$3 \sigma=0.685$ & & & & \\
\hline
\end{tabular}

This table reports new linear predictions for TIC based on coefficients estimated for model 2, (i.e., test of the bifurcated sample). Given significance in the SRS $\times$ ECON term (H3), TIC is estimated at four points that are equivalent to departures from SR equilibrium: the mean $(\mu)$ of the SRS observations is closest to SR equilibrium $(\mathrm{SR}=0)$ and each standard deviation marks a larger departure from SR equilibrium. ECON levels chosen are in increments of 0.5, between values of -2.0 (poor economic outlook) to +2.0 (good economic outlook). 
Table 14

Regression results for test of SR persistence (post hoc analysis for sample period 2005-2012)

\begin{tabular}{|c|c|c|c|}
\hline Dependent variable (TIC) & Variable & $\begin{array}{c}(1) \\
\text { No ECON }\end{array}$ & $\begin{array}{c}(2) \\
E C O N^{a}\end{array}$ \\
\hline SR persistence & SRPERSIST & $\begin{array}{l}2.252 * * * \\
(2.89)\end{array}$ & $\begin{array}{l}0.636 \\
(0.60)\end{array}$ \\
\hline State leading index & ECON & $\mathrm{n} / \mathrm{a}$ & $\begin{array}{l}-0.096 * * * \\
(-2.17)\end{array}$ \\
\hline \multicolumn{4}{|l|}{ Control variables: } \\
\hline Unassigned fund balance & FB & 0.080 & 0.170 \\
\hline \multirow[t]{3}{*}{ Yield curve attributes } & SLOPE & $0.056 * * *$ & $0.053 * * *$ \\
\hline & CURVE & $-2.371 * * *$ & $-2.090 *$ \\
\hline & LEVEL & -0.098 & -0.015 \\
\hline \multirow[t]{4}{*}{ Bond characteristics } & AMT & $-0.152 * * *$ & $-0.157 * * *$ \\
\hline & BID & -0.131 & -0.161 \\
\hline & $\mathrm{BR}$ & 0.231 & 0.280 \\
\hline & CALL & -0.011 & 0.080 \\
\hline \multirow[t]{5}{*}{ Within cluster on counties } & & included & included \\
\hline & N (bonds) & 100 & 100 \\
\hline & F-statistic ${ }^{b}$ & 13.97 & 14.19 \\
\hline & Prob $>$ F & 0.0000 & 0.0000 \\
\hline & $\mathrm{R}^{2}$ (overall) & 0.4956 & 0.5183 \\
\hline \multicolumn{4}{|c|}{$\begin{array}{l}*, * *, * * * \text { indicate significance at } \mathrm{p}<0.100, \mathrm{p}<0.050, \mathrm{p}<0.010 \text { levels, respectively (two-tailed). } \\
\text { a } \mathrm{t} \text {-statistics for independent variables are in parentheses using robust standard errors by county. } \\
\text { b Degrees of freedom are }(9,49) \text { in column } 1 \text { and }(10,49) \text { in column } 2 \text {. } \\
\text { This table reports regression results for post hoc analysis for spending rate persistence } \\
\text { (SRPERSIST). SRPERSIST is the R-squared from the autoregressive regression estimation of } \\
\text { SR lagged no more than three previous years. Column } 1 \text { shows significance in spending rate } \\
\text { volatility (SRPERSIST) at } 2.252(p<0.010) \text {. Column } 2 \text { shows significance for the state leading } \\
\text { index (ECON) at }-0.075(p<0.010) \text {; SRPERSIST is nonsignificant upon inclusion of ECON. }\end{array}$} \\
\hline
\end{tabular}




\section{Appendix B - Figures}

\section{Figure 1}

Average TIC, SR, ECON, and LEVEL values from 1995-2014 (inclusive)

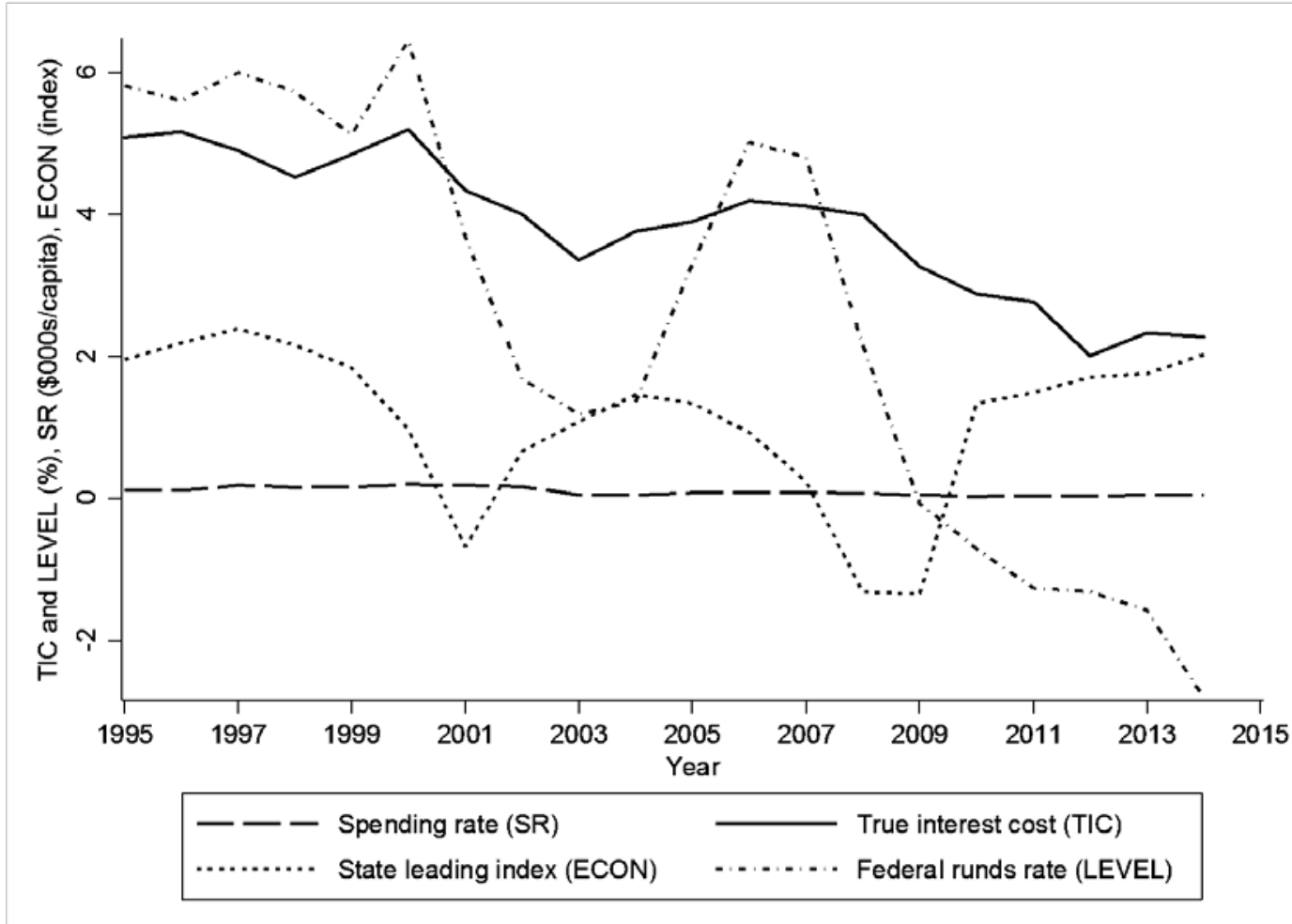

This figure presents cross-sectional means for the dependent variable (TIC), independent variables (SR and ECON), and a yield curve attribute, the federal funds rate control variable (LEVEL). TIC shows an overall decline across the sample period. Relative to ECON, SR is fairly stable across the sample period. ECON shows dips below zero during recession years (early 2001 and the tech bubble; late 2007 financial crisis and subsequent recession). The overall average trend ECON shows that it does not necessarily move in sequence with LEVEL. 
Figure 2

Average SR, SR surpluses, and SR deficits from 1995-2014 (inclusive).

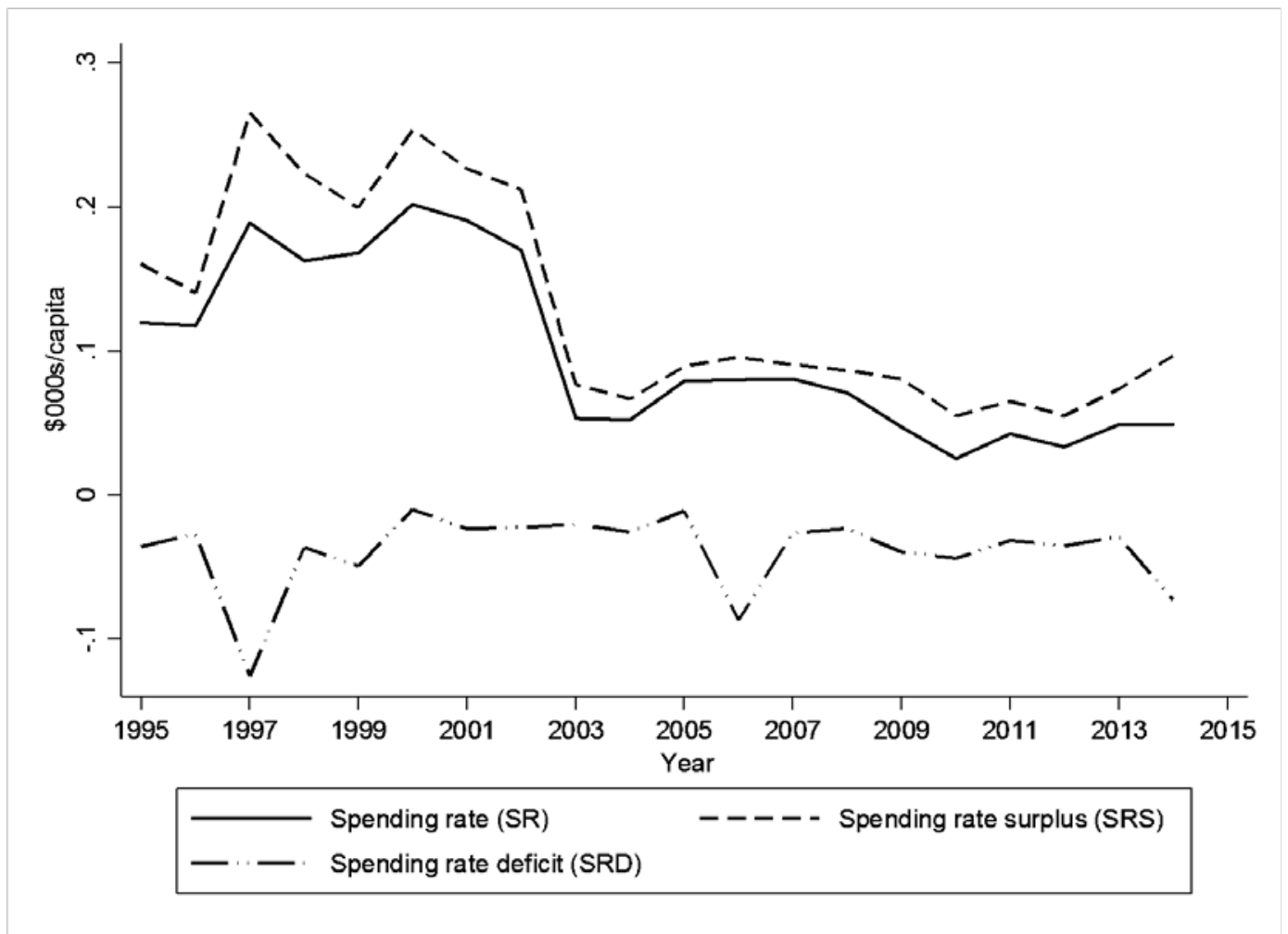

This figure presents cross-sectional means for spending rate surplus and spending rate deficit (not magnitudes). The largest levels of deficits and surpluses coincide with years of growth in economic history. A sharp decline is evident in surpluses starting in 2002. 


\section{Figure 3}

Average SR deficits and unassigned fund balances from 1995-2014 (inclusive).

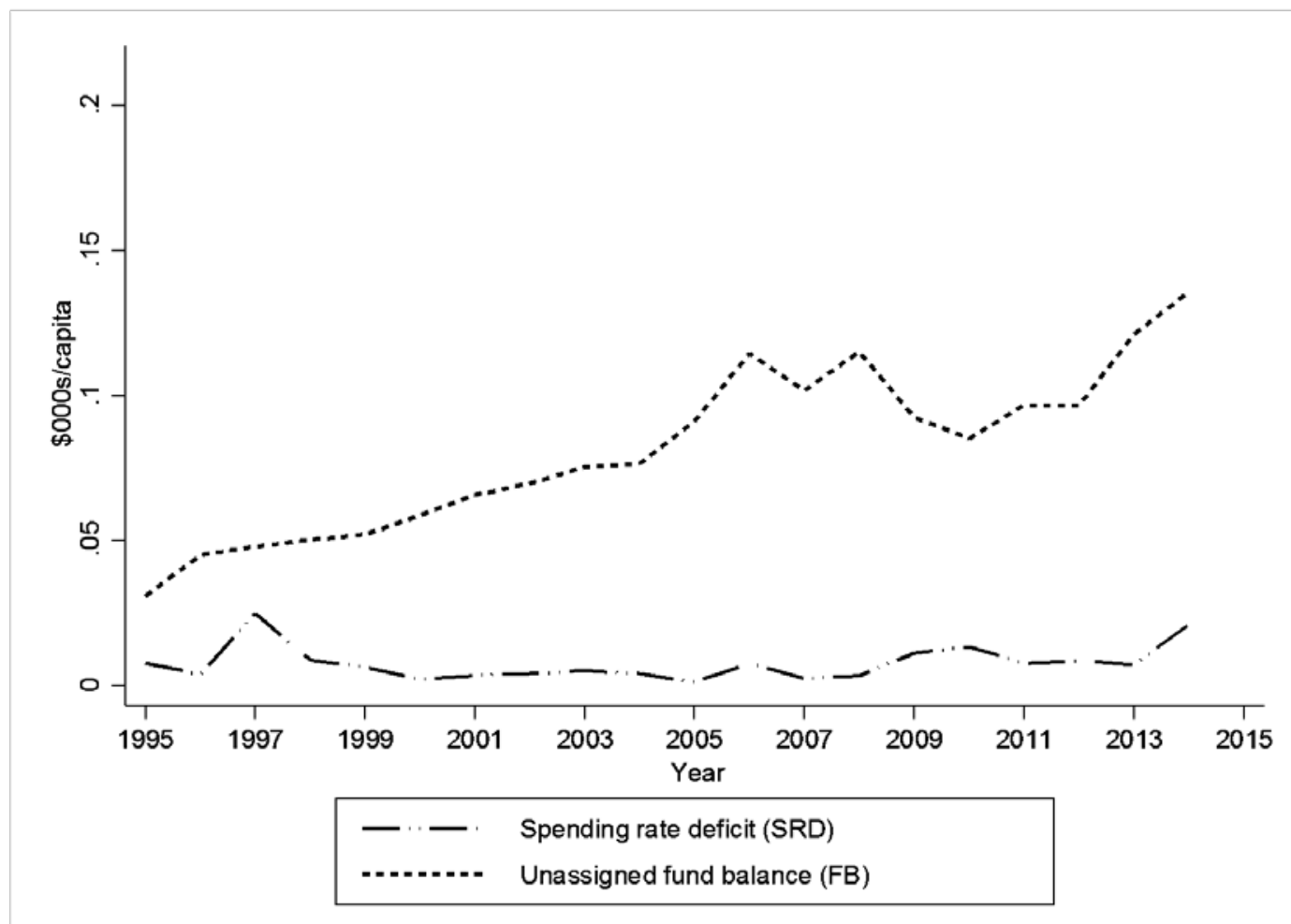

This figure presents the cross-sectional means of the magnitude of spending rate deficit (SRD) and unassigned fund balance (FB). A comparison of SRD, relative to the size of FB, shows an overall increase in FB levels while SRD remained stable across the sample period. A larger FB relative to SRD can better enable a municipality to compensate for deficits (Apostolou, 1982). 


\section{Figure 4}

Average SR and corresponding revenues and expenditures from 1995-2014 (inclusive)

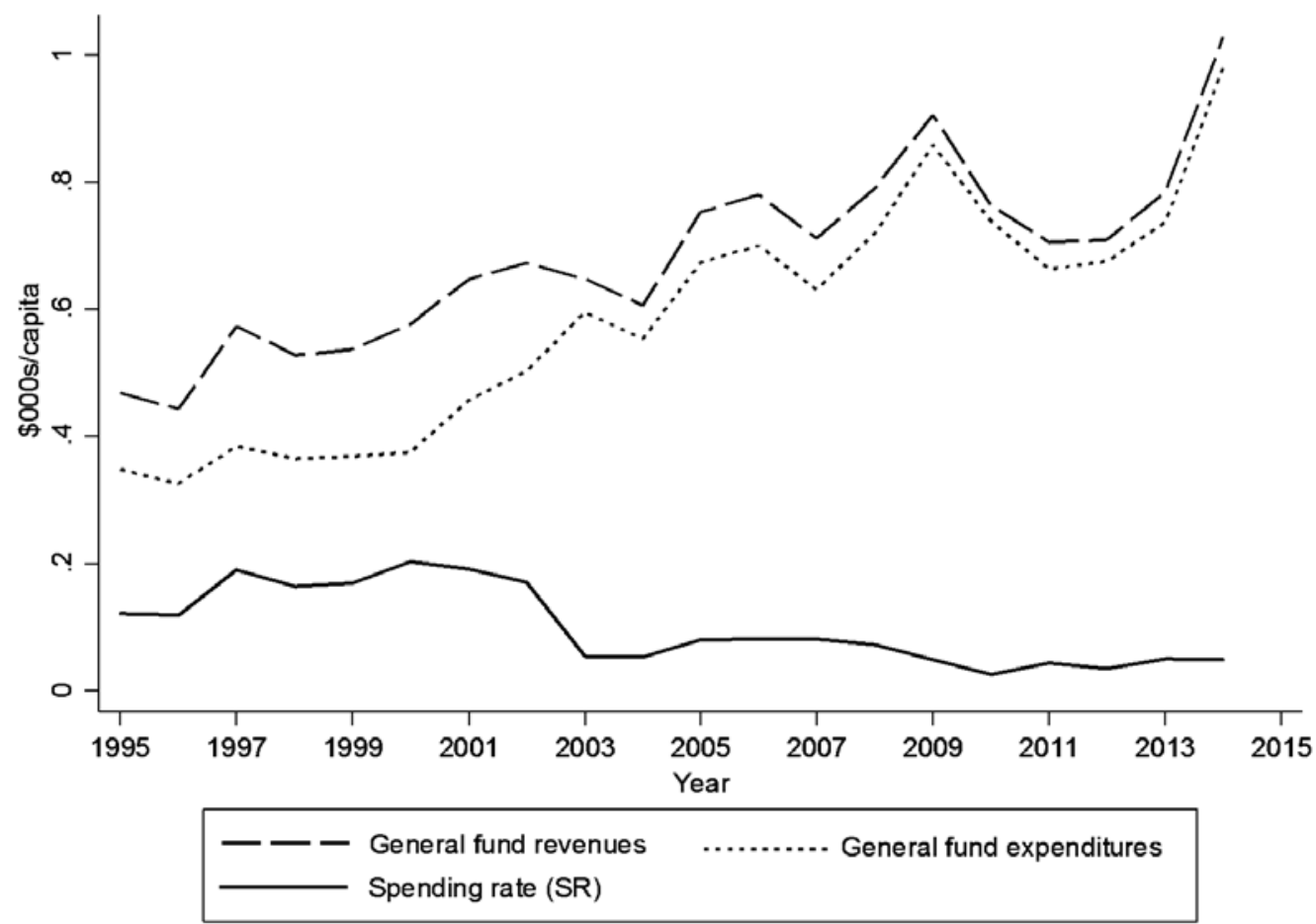

This figure presents the cross-sectional means of spending rate (SR) and its corresponding determinants of general fund revenues (GFREV) and general fund expenditures (GFEXP). Despite variation in GFREV and GFEXP, SR appears fairly stable across the sample. A noticeable dip appears for GFREV and GFEXP starting in 2009 to approximately 2012. This dip in GFREV and GFEXP are consistent with a prolonged recovery due to declines in revenues after the financial crisis Gross et al. (2012). 


\section{Appendix C - Overview of GASB Statement No. 34}

The governmental financial reporting model is summarized in GASB’s Statement No. 34. Financial reporting per Generally Accepted Accounting Principles (GAAP) is accomplished through a governmental entity's Comprehensive Annual Financial Report (CAFR). The CAFR is comprised of a set of financial statements that are prepared in two ways: (1) government-wide financial statements are prepared using the full accrual basis of accounting and an "economic resources” measurement focus, and (2) fund-based financial statements for governmental funds are prepared using the modified accrual basis of accounting and a "current financial resources" measurement focus (GASB 1999; Plummer et al., 2007). ${ }^{37}$ Government-wide reporting provides a better picture of economic position while fund-based reporting provides a better picture of performance and fiscal accountability over current resources (Plummer et al., 2007).

The "general fund" is the main operating fund of a municipality. As a major governmental fund, the recognition of revenues and expenditures is reported under the modified accrual basis of accounting, which combines aspects of both the cash basis and the full accrual basis of accounting. Per the modified accrual basis of accounting, general fund revenues should be deferred until they are “measurable and available,” while general fund expenditures are recorded when "claims against current financial resources take place, regardless of when cash is paid” (GASB, 1990).

The revenue component of SR is largely comprised of revenues that result from nonexchange transactions (Reck and Wilson, 2014). Non-exchange transactions occur when a government “...gives (or receives) value from another party without directly receiving (or giving) equal value in return” (GASB, 1998). Examples of non-exchange revenues are

\footnotetext{
${ }^{37}$ Proprietary and fiduciary fund financial statements are prepared under the full accrual basis of accounting with an economic resources measurement focus.
} 
intergovernmental grants, entitlements, and property, sales, and personal and corporate income taxes (GASB, 1998). The expenditure component of SR generally consists of current operating expenditures that should be classified, at a minimum, by function. Any debt service or small capital expenditures that are charged to the general fund are usually presented separately from current operating expenditures.

The difference between general fund revenues and expenditures (i.e., SR) are reported as either a surplus or deficit on the Statement of Revenues, Expenditures, and Changes in Fund Balance (GASB 34). ${ }^{38}$ Accordingly, SR can be thought of as a modified-accruals measure of "earnings" in the general fund (Plummer et al., 2007). Importantly, SR should not be confused with the term "fund balance." The "fund balance" represents the net of assets minus fund liabilities and is reported on the Balance Sheet for governmental funds. ${ }^{39}$ Any surplus or deficit from the management of revenues over expenditures during the accounting period will increase or decrease, respectively, the general fund balance from the prior accounting period. Thus, the general fund's fund balance is an accumulation of surpluses or deficits from each accounting period. Reck and Wilson (2014) highlight the significance of the unreserved (or unassigned) portion of an entity's fund balance as a key indicator in assessing default risk. The GFOA recommends that governments maintain a fund balance of “...no less than two months of general fund operating revenues or regular general fund operating expenditures." ${ }^{40}$

Unlike the private sector, GASB Statement No. 54 requires governmental entities that follow GAAP to further classify fund balance by imposed spending constraints. Five levels of

\footnotetext{
38 "SR" or "spending rate" (revenues/expenditures) is not a term that is used on CAFRs. Rather, SR is represented as a surplus (excess) or deficit (deficiency) of revenues over expenditures.

${ }^{39}$ For government-wide reporting (full accrual basis), the financial statements are called the Statement of Net Position (financial position) and the Statement of Activities (operating performance).

${ }^{40}$ GFOA's “Best Practice” resource, titled Appropriate Level of Unrestricted Fund Balance in the General Fund at http://www.gfoa.org/appropriate-level-unrestricted-fund-balance-general-fund
} 
spending constraints are identified in GASB Statement No. 54, with "non-spendable” denoting the most constrained portion of fund balance. Per Reck \& Wilson (2014), the unassigned fund balance that is prevalently used as a control variable in governmental accounting and public finance research is the unassigned fund balance. Table C.1. summarizes the basic differences between spending rate and fund balance.

\section{Table C.1.}

Spending rate versus fund balance.

\begin{tabular}{|c|c|c|}
\hline Characteristics & Spending rate & Fund balance \\
\hline $\begin{array}{l}\text { Name of the fund } \\
\text { financial statement }\end{array}$ & $\begin{array}{l}\text { Statement of revenues, expenditures, and } \\
\text { changes in fund balances }\end{array}$ & $\begin{array}{l}\text { Balance sheet for } \\
\text { governmental funds }\end{array}$ \\
\hline $\begin{array}{l}\text { Core equation and } \\
\text { presentation }\end{array}$ & $\begin{array}{l}\text { Revenues }- \text { expenditures = surplus } \\
\text { (deficit) }\end{array}$ & $\begin{array}{l}\text { Assets }- \text { liabilities = } \\
\text { fund balance }\end{array}$ \\
\hline Time period & $\begin{array}{l}\text { Covers general fund performance over } \\
\text { the accounting period } \\
\text { (usually over a fiscal year) }\end{array}$ & $\begin{array}{l}\text { Provides general fund } \\
\text { position at a point in } \\
\text { time (usually at fiscal- } \\
\text { year end) }\end{array}$ \\
\hline $\begin{array}{l}\text { Basis of accounting } \\
\text { and measurement }\end{array}$ & $\begin{array}{l}\text { Modified accrual basis and } \\
\text { current financial resources }\end{array}$ & $\begin{array}{l}\text { Modified accrual basis } \\
\text { and current financial } \\
\text { resources }\end{array}$ \\
\hline $\begin{array}{l}\text { Articulation between } \\
\text { financial statements }\end{array}$ & $\begin{array}{l}\text { Surpluses increase prior fund balance } \\
\text { Deficits decrease prior fund balance }\end{array}$ & $\begin{array}{l}\text { Fund balance represents } \\
\text { an accumulation of } \\
\text { surpluses or deficits } \\
\text { from prior periods }\end{array}$ \\
\hline $\begin{array}{l}\text { Constraints on } \\
\text { spending }\end{array}$ & $\begin{array}{l}\text { Conditional on a governmental entity's } \\
\text { adopted budget and/or any revenue and } \\
\text { expenditure policies }\end{array}$ & $\begin{array}{l}\text { GASB Statement No. } 54 \\
\text { requires classification of } \\
\text { the available fund } \\
\text { balance by the spending } \\
\text { constraints that are } \\
\text { imposed: nonspendable, } \\
\text { restricted, committed, } \\
\text { assigned, unassigned } \\
\text { fund balance }\end{array}$ \\
\hline
\end{tabular}

